Portland State University

PDXScholar

\title{
Geophysical and geochemical analyses of selected Miocene coastal basalt features, Clatsop County, Oregon
}

Virginia Josette Pfaff

Portland State University

Follow this and additional works at: https://pdxscholar.library.pdx.edu/open_access_etds

Part of the Geochemistry Commons, Geophysics and Seismology Commons, and the Stratigraphy Commons

Let us know how access to this document benefits you.

\section{Recommended Citation}

Pfaff, Virginia Josette, "Geophysical and geochemical analyses of selected Miocene coastal basalt features, Clatsop County, Oregon" (1980). Dissertations and Theses. Paper 3184.

https://doi.org/10.15760/etd.3175

This Thesis is brought to you for free and open access. It has been accepted for inclusion in Dissertations and Theses by an authorized administrator of PDXScholar. Please contact us if we can make this document more accessible: pdxscholar@pdx.edu. 
AN ABSTRACT OF THE THESIS OF Virginia Josette Pfaff for the Master of Science in Geology presented December 16, 1980.

Title: Geophysical and Geochemical Analyses of Selected Miocene Coastal Basalt Features, Clatsop County, Oregon.

APPROVED BY MEMBERS OF THE THESIS COMMITTEE:
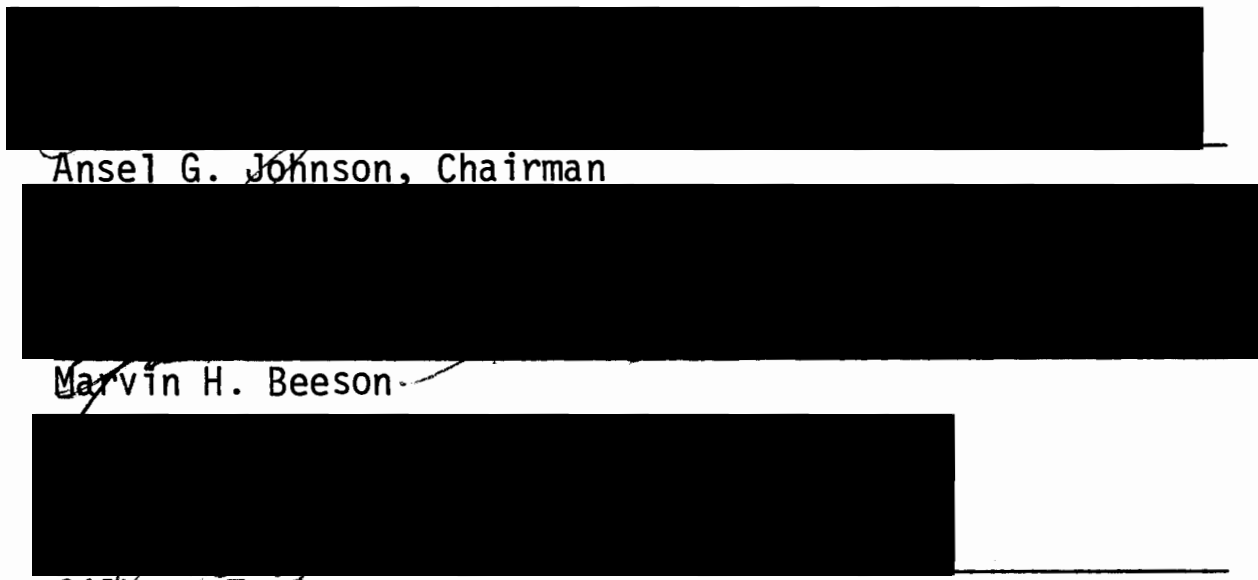

Gilbert T. Benson

The proximity of Miocene Columbia River basalt flows to "locally erupted" coastal Miocene basalts in northwestern Oregon, and the compelling similarities between the two groups, suggest that the coastal basalts, rather than being locally erupted, may be the westward extension of plateau basalts derived from eastern Oregon and Washington. Selected coastal basalts in Clatsop county, Oregon, were examined geochemically and geophysically; the data lend credence to a plateau origin for the coastal basalts.

Analysis by Instrumental Neutron Activation Analysis and fluxgate 
magnetometer allowed classification of 36 coastal basalt samples into three chemical types correlative with only those Columbia River basalt plateau flows also found in western Oregon: reversed $\left(R_{2}\right)$ and normal $\left(\mathrm{N}_{2}\right)$ low Mg Depoe Bay Basalt, high Mg Depoe Bay Basalt, and Cape Foulweather Basalt (coasta1) correlate respectively with reversed $\left(R_{2}\right)$ and normal $\left(\mathrm{N}_{2}\right)$ low Mg Grande Ronde Basalt, high Mg Grande Ronde Basalt, and the Frenchman Springs Member of the Wanapum Basalt (plateau). 01der Miocene coastal basalts (low Mg Depoe Bay) are found to occur furthest inland, separating the Eocene and plateau basalts to their east from the younger Miocene coastal basalts to their west. A seemingly regional series of low Mg Depoe Bay basalt dikes trending southwest from Nicolai Mountain is actually composed of both reversed and normal flows and can no longer be presumed to indicate a single long fissure. The high Mg Depoe Bay basalt breccia at Saddle Mountain overlies older low Mg basalt; adjacent dikes are also low Mg basalt and could not have served as feeders for the breccia peak. Although Cape Foulweather basalt outcrops along the South Fork of the Klaskanine River are abundantly phyric (Ginkgo unit), geochemically distinct Cape Foulweather basalt along Youngs River and west of the Lewis and Clark River is sparsely porphyritic (Sand Hollow unit). Distribution patterns based on isolated outcrops of basalt types lend themselves to varied interpretations but suggest topographic control by the Eocene highlands and stream valleys.

Gravity traverses conducted over coastal basalt features allow the formulation of models indicating the depth to which such features might extend. The linear, low Mg Depoe Bay basalt dikes underlying Fishhawk Falls (normally polarized) and Denver Point (reversed) extend only 
$107 \mathrm{~m}$ and $45 \mathrm{~m}$, respectively, below the surface. The U-shaped Cape Foulweather basalt dike at Youngs River Falls may be modelled as a shallow (maximum depth $.23 \mathrm{~km}$ below sea level) or deep (minimum depth $.3 \mathrm{~km}$ below sea level) syncline. Alternatively, the basalt might encircle either a hill of somewhat denser sedimentary rock or a buried Eocene volcanic high, in which cases the basalt limbs independently extend 200-300 m below sea level. Arcuate segments of the low Mg Depoe Bay basalt "ring dike" on the Klaskanine River apparently are not connected at depth; the southwest crescent is $100 \mathrm{~m}$ deep, while the northeast crescent is an apophys is from a $150 \mathrm{~m}$ thick basalt mass. Abundantly phyric Cape Foulweather basalt outcrops consistently proved to be shallow (100 m or less below the surface). Vertical dikes extending to the Eocene volcanic basement are not suitable for any of the features investigated, while shallow, near surface basalt masses are either preferred or distinctly possible in all cases. 
GEOPHYSICAL AND GEOCHEMICAL ANALYSES OF SELECTED MIOCENE COASTAL BASALT FEATURES, CLATSOP COUNTY, OREGON

by

VIRGINIA JOSETTE PFAFF

A thesis submitted in partial fulfillment of the requirements for the degree of

MASTER OF SCIENCE

in

GEOLOGY

Portland State University

1981 
TO THE OFFICE OF GRADUATE STUDIES AND RESEARCH:

The members of the Committee approve the thesis of Virginia Josette Pfaff presented December 16, 1980.

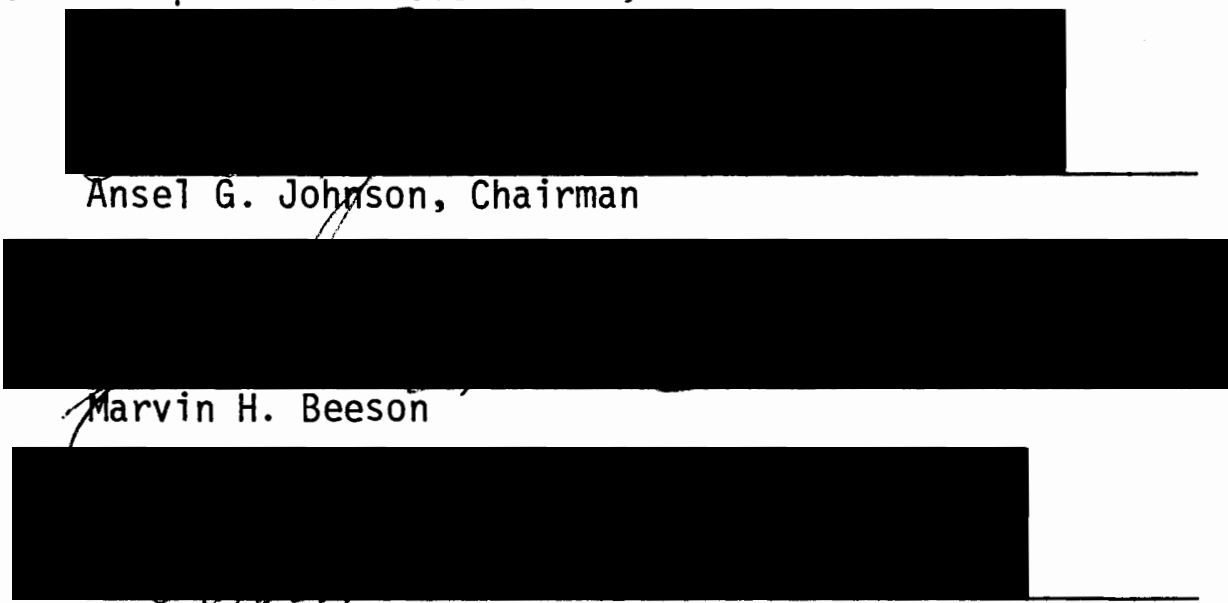

Gilbert T. Benson

APPROVED :

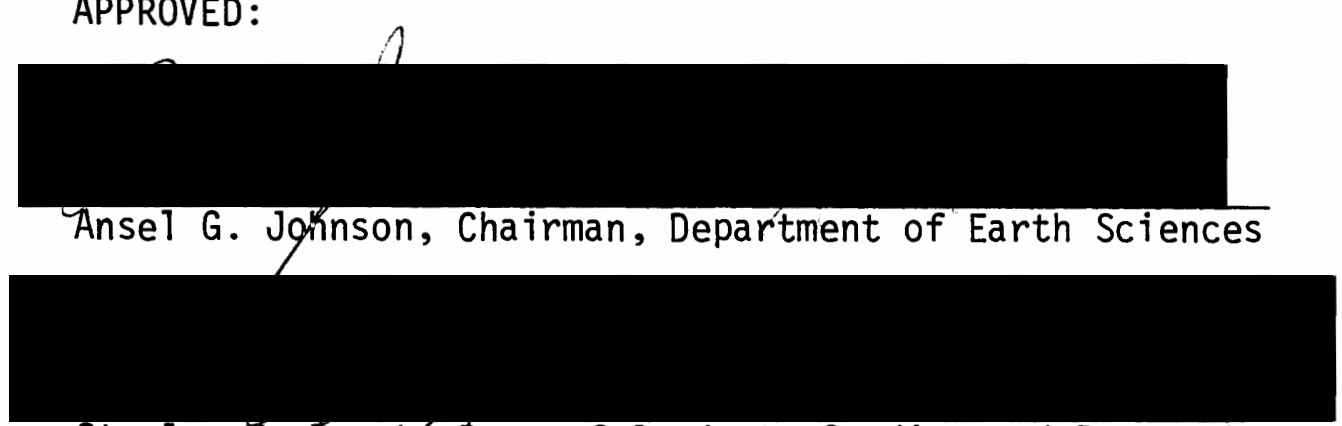

Stanley E. Rauch, Dean of Graduate Studies and Research 


\section{ACKNOWLEDGMENTS}

My grateful appreciation and thanks are extended to my advisor, Ansel Johnson, Earth Sciences Department, for his continued guidance, encouragement, and patience. I also thank the members of my thesis committee, Marvin Beeson and G.T. Benson, Earth Sciences Department, and Gene Enneking, Math Department, for their efforts and advice in reviewing the manuscript.

I thank LeAnna Grenz, Fred Gullixson, Barbara Portwood, Cindy Veen, and especially Janet Malloch and John Oggerino for their willing help with the field work. Mike Moran gave me much-appreciated moral support and coffee breaks. My particular thanks are reserved for John Oggerino, whose assistance and good humor were unfailing.

The School of Oceanography, Oregon State University, kindly loaned me the gravimeter and seismic refraction equipment, and Crown Zellerbach, Inc., generously provided access to maps and aerial photographs.

This research was supported in part both by a Sigma Xi Grant-inAid of Research and by Research Assistance from Mazamas, Inc. 
TABLE OF CONTENTS

PAGE

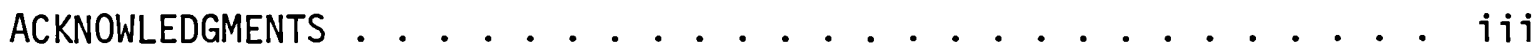

LIST OF FIGURES . . . . . . . . . . . . . . . . . . . vi

INTRODUCTION . . . . . . . . . . . . . . . . . . . . . 1

STATEMENT OF THE PROBLEM ..................... 1

PURPOSE AND SCOPE .................... 12

GEOGRAPHIC SETTING . . . . . . . . . . . . 13

PREVIOUS MAPPING . . . . . . . . . . . . . . 15

FIELD WORK .................... 16

WESTERN OREGON GEOLOGY ................... . 18

REGIONAL GEOLOGIC HISTORY OF WESTERN OREGON . . . . . . . 18

DISTRIBUTION OF MIOCENE BASALT IN WESTERN OREGON . . . . . . 24

MODE OF OCCURRENCE OF MIOCENE BASALT IN WESTERN OREGON . . . . 30 GEOCHEMISTRY . . . . . . . . . . . . . . . 36

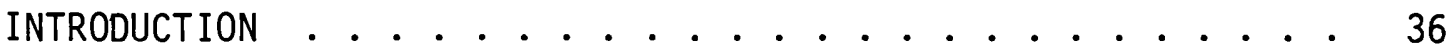

PROCEDURES ..................... 38

RESULTS AND DISCUSSION ................ . . 41

Identification and Distribution ........... 41

Low Mg Depoe Bay . . . . . . . . . . . . . 43

High Mg Depoe Bay. . . . . . . . . . . . . . . 49

Cape Foulweather . . . . . . . . . . . 50

Pattern.................... 53 
PAGE

GEOPHYSICS .................... . . . 60

INTRODUCTION . . . . . . . . . . . . . . . 60

PROCEDURES ............................. 61

RESULTS AND DISCUSSION ....................... 69

Fishhawk Falls-Denver Point . . . . . . . . 69

Youngs River Falls............... 82

Klaskanine River...................... 111

SUMMARY AND CONCLUSIONS .................. . . . . 124

REFERENCES ........................... 129

APPENDIX A . . . . . . . . . . . . . . . . 137

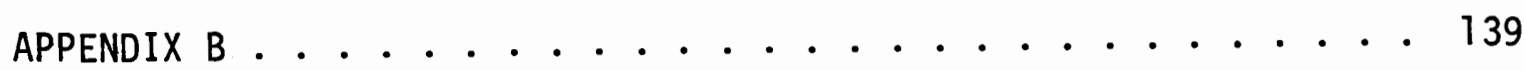

APPENDIX C . . . . . . . . . . . . . . . . . 140

APPENDIX D . . . . . . . . . . . . . . . . . 142

APPENDIX E . . . . . . . . . . . . . . . . 149 


\section{LIST OF FIGURES}

FIGURE

PAGE

1. Distribution of Columbia River Basalt Group in Oregon, Washington, and Idaho ............ 2

2. Columbia River Basalt Group Stratigraphy . . . . . . . 4

3. Areal Distribution of Plateau and Coastal Basalts in Western Oregon and Washington ......... 5

4. Distribution of Coastal Basalt Features and Vent Areas . . 8

5. Geographic Index Map of the Study Area . . . . . . . . 14

6. Regional Geologic Map .............. . 19

7. Stratigraphy of Columbia River Basalt Group in Western Oregon ...................... 25

8. Areal Distribution of Coastal Basalts and Post-Eocene

Sediments in Western Washington and Oregon ..... 31

9. Location Map of Geochemistry Samples and Basalt Types . . 40

10. Plot of Fe vs. La Concentrations ........... . 43

11. Plot of La/Sm vs. Eu Concentrations ........... 44

12. Plot of Fe vs. Sc Concentrations . . . . . . . . . 45

13. Plot of Fe vs. Th Concentrations . . . . . . . . 46

14. Location Map of Gravity Traverses over Coastal Basalt

Features ................ 62

15. Regional Complete Bouguer Gravity Anomaly Map of Northwest Oregon ............. . 66 
16. Regiona1 Free Air Gravity Anomaly Map of Northwestern Oregon ........................... 67

17. J Line Gravity Traverse Over Fishhawk Falls and Denver Point ............. . . 70

18. Location of Wells Used in Regional Upper Crust Models . . 71

19. Comparison of Observed and Calculated CBA for J Line . . . . . . . . . . . . . . . . 74

20. Effect of Infinite Vertical Dikes on Calculated CBA

for the J Line . . . . . . . . . . . . 76

21. Observed FAA and Preferred FAA Model for the J Line . . 77

22. Youngs River Falls Gravity Traverses (Lines $P, A-B$,

$S-N, 80$ ), Refraction Surveys (Lines $Q, W, G$ ), and Magnetic Profile............. 83

23. Comparison of Observed and Calculated CBA for the A-B-P Line . . . . . . . . . . . . 87

24. Effect of Infinite Vertical Dikes on the Calculated CBA

for the A-B-P Line . . . . . . . . . . . 89

25. FAA Model of Shallow Syncline for A-B-P Line . . . . . 90

26. FAA Model of Deep Syncline for A-B-P Line . . . . . . . 96

27. Effect of a $.1 \mathrm{~g} / \mathrm{cc}$ Density Contrast Across the Fault

on the A-B-P Line . . . . . . . . . . . . . 97

28. Effect of a Topographic Hill of Somewhat Denser

Sedimentary Rock on the A-B-P Line FAA . . . . . . . 99

29. Observed CBA and FAA for the $\mathrm{S}-\mathrm{N}-80$ Line . . . . . . . 101 
30. Magnetic Profile Over the Small Basalt Feature

Southeast of Youngs River Falls ......... 103

31. Refraction Line Measuring Velocity of the Basalt at

Youngs River Falls Quarry........... 105

32. Refraction Line $G$, Located with the U Interior . . . . 106

33. Refraction Line W, 10 Foot Spacing, Anchored on SE Limb . . 107

34. Refraction Line W, 50 Foot Spacing, Anchored on SE Limb . 108

35. Aeromagnetic Anomaly Map ... . . . . . . . . 109

36. Magnetic Profile A-A' from Aeromagnetic Anomaly Map . . . 110

37. Gravity Traverses Across Dike on the South Fork of the

Klaskanine River, T-M Line ......... . 112

38. Comparison of Observed and Calculated CBA for the

T-M Line .............. . . . 115

39. Effect of Infinite Vertical Dikes on Calculated FAA

for the T-M Line ............. . 116

40. FAA Model of Independent Dikes for the T-M Line . . . . 119

41. FAA Model of Connected Dikes for the T-M Line . . . . . 122 


\section{INTRODUCTION}

The proximity of Miocene Columbia River basalts to the "locallyerupted" coastal Miocene basalts in northwestern Oregon, and the compelling similarities between the two groups, suggest that the coastal basalts, rather than being locally erupted, may be the westward extension of plateau basalts derived from eastern Oregon and washington.

The 1oca1-origin hypothesis is based largely on the interpretation of coastal dikes and sills as representing vent areas; however, a complex mechanism, as yet unsatisfactorily defined, would be required to cause the eruption of virtually identical magmas simultaneously from source areas $500 \mathrm{~km}$ apart.

This study, therefore, has investigated the coastal basalt intrusions both laterally and vertically. Geochemical and paleomagnetic analysis was used to determine the occurrence and distribution of basalt units; gravity surveys enabled an examination of the subsurface extensions of basalt intrusions in sedimentary rocks.

\section{STATEMENT OF THE PROBLEM}

The Columbia River Basalt Group of Oregon, Washington, and Idaho is a series of tholeitic flood basalts erupted between 16 and 6 my ago during the Miocene epoch, which lasted from 23.5 to 5.3 my bp (Holmgren, 1970; Watkins and Baksi, 1971; Niem and Cressy, 1973; McKee and others, 1977; Swanson and others, 1979). The basalts now cover an area $2 \times 10^{5} \mathrm{~km}^{2}$ at an estimated volume of $2 \times 10^{5} \mathrm{~km}^{3}$ (Waters, 1961) (Figure 1). 


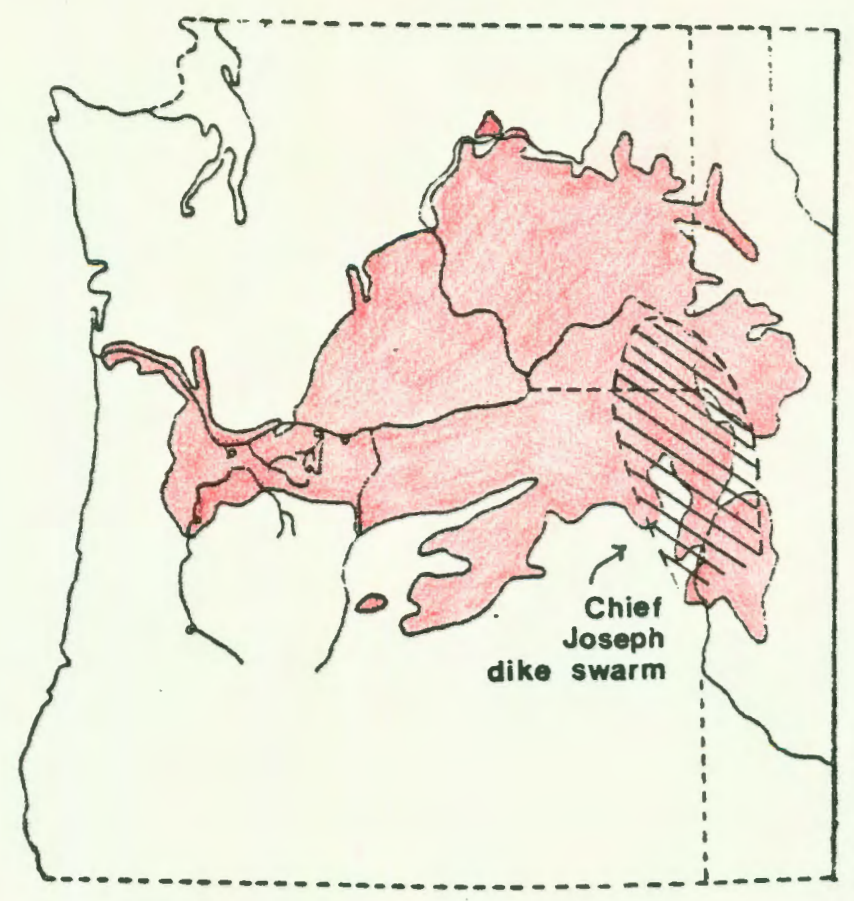

Figure 1. Distribution of Columbia River Basalt Group in Oregon, Washington, and Idaho. (After Waters, 1961). (Modified from Beeson and Moran, 1979).

By far the most voluminous within this series is the Yakima Basalt Subgroup, which was erupted from north-northwest-trending fissures now represented by the Chief Joseph dike swarm (Waters, 1961; Taubeneck, 1970; Swanson and others, 1975) of northeastern Oregon, southeastern Washington, and western Idaho. These fluid Yakima "plateau" basalts spread out over the Columbia Plateau, attaining a maximum thickness of $1500 \mathrm{~m}$ in the Pasco Basin of Washington (Asaro, 1978 in Beeson and others, 1979b). Of these Yakima lavas, at least 26 flows with a composite stratigraphic thickness of $550 \mathrm{~m}$ flowed into western Oregon through a structural gap in the western Cascades located between the Columbia River Gorge and the Clackamas River drainage (Beeson and Moran, 1979). These Yakima basalts are of particular interest to this study as 
they are the only Columbia River basalt flows which thus far have been traced into western Oregon (Beeson and others, 1979a).

The basalt stratigraphy has been determined primarily by lithology, geochemistry, stratigraphic position, and magnetic polarity, and has been revised as investigations have increased and techniques have been refined. According to the revised stratigraphic nomenclature approved by the U.S. Geological Survey (Swanson and others, 1979), there are five formations within the Columbia River Basalt Group, of which the youngest three constitute the Yakima basalts (Figure 2). A11 three of these younger formations are represented by at least one flow in western Oregon; the older two formations, Imnaha and Picture Gorge basalts, are restricted to relatively small areas south and southeast of the Plateau province (Swanson and Wright, 1978).

The three Yakima basalt formations, in order of both decreasing age and decreasing numbers of western Oregon flows, are the Grande Ronde, Wanapum, and Saddle Mountains basalts (Swanson and others, 1979), equivalent respectively to the Lower, Middle, and Upper Yakima basalts of Wright and others (1973) and to the Yakima basalt and late-Yakima variant of Waters (1961) and Pomona flow of Schmincke (1964). These flood basalts which originated in eastern Oregon and Washington and flowed westward, covering and/or crossing the Columbia Plateau, are referred to here as "plateau basalts."

Additional outcrops of Miocene tholeiitic basalt have been mapped along the Pacific coast from Seal Rocks, Oregon, to Grays Harbor, Washington (Schlicker and others, 1972; Beaulieu, 1973; Snavely and others, 1973) (Figure 3). They constitute three formations consanguin- 


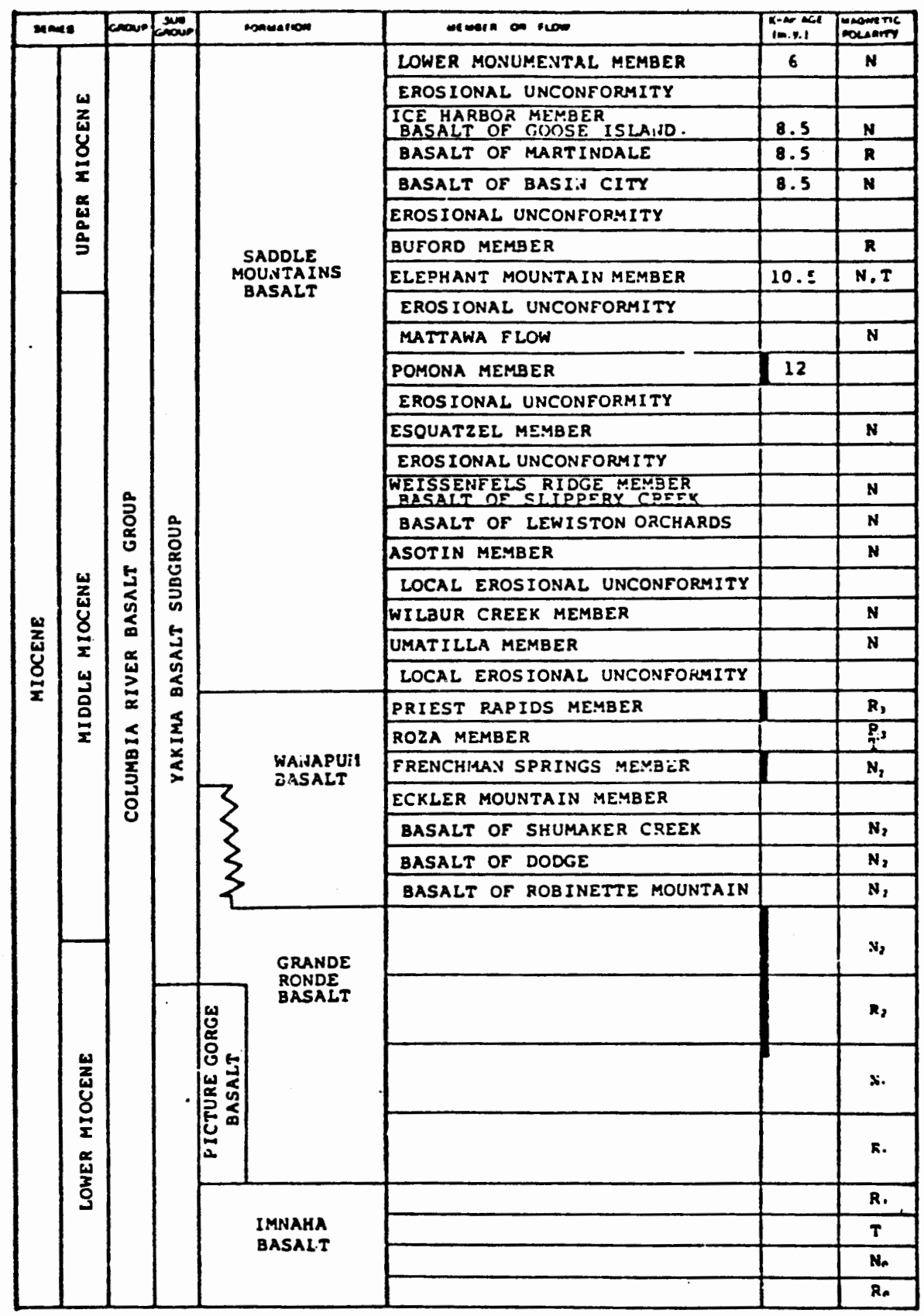

Figure 2. Colunbia River Basalt Group stratigraphy. Bars indicate members occurring in western Oregon. (After Swanson, 1978). (From Beeson and Moran, 1979). 


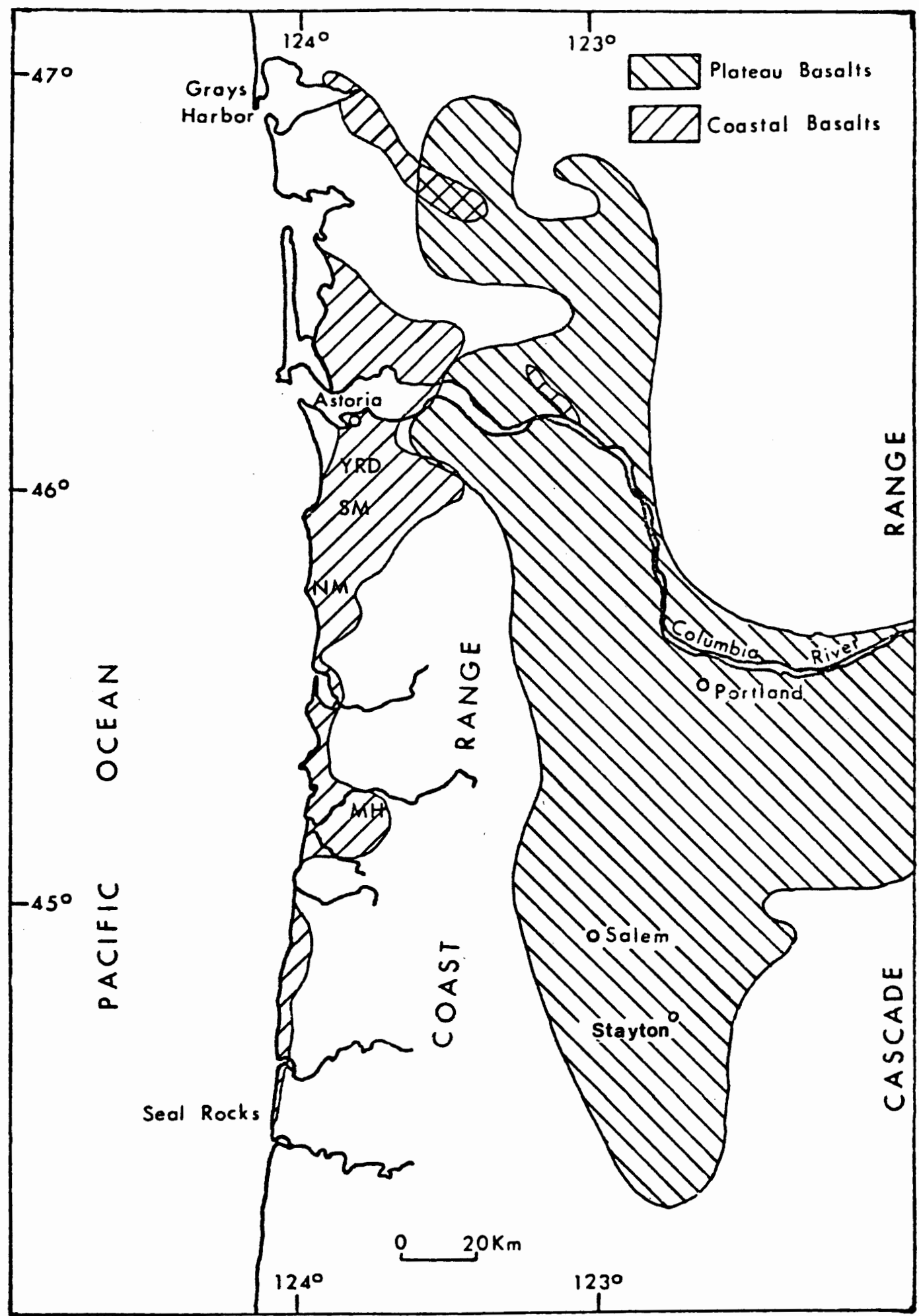

Figure 3. Areal distribution of plateau and coastal basalts in western Oregon and Washington. (Modified from Snavely and others, 1973). (From Beeson and others, 1979b). 
eous with the three Yakima basalt formations and have been named, in order of decreasing age, the Depoe Bay Basalt, Cape Foulweather Basalt, and basalt of Pack Sack Lookout (Snavely and others, 1973). These "coastal basalts" correlate with the plateau basalts as follows:

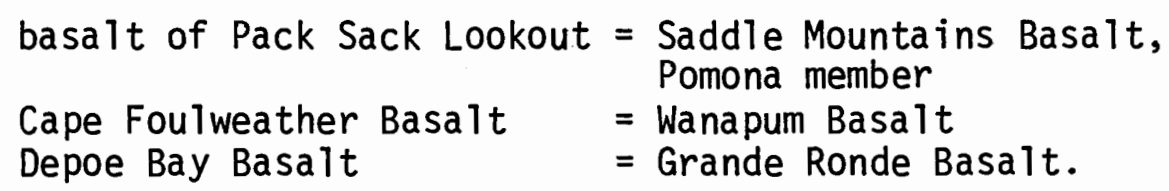

Within each coastal-plateau basalt pair, the basalts are indistinguishable from each other on the bases of 1 ithology and petrography, (Dodds, 1963; Kienle, 1971; Snavely and others, 1973), major element geochemistry (Snavely and others, 1973), minor/trace element geochemistry (Nathan and Fruchter, 1974; Hil1, 1975), magnetic polarity (Kienle, 1971; Choiniere and Swanson, 1979), strontium isotope ratios (McDouga11, 1976), uranium-lead isotope ratios (Tatsumoto and Snavely, 1969), stratigraphic succession (Snavely and others, 1973), and age (Niem and Cressy, 1973; Snavely and others, 1973). Furthermore, the mapped areas of occurrence of coastal and plateau basalts overlap in western Oregon (Figure 3 ). Notice that the southernmost extents of plateau and coastal basalts (Stayton and Seal Rocks, Oregon, respectively) lie along nearly the same line of latitude.

Based largely on the field evidence of the frequent occurrence of coastal basalts as dikes, sills, and other irregular intrusions of the same composition as the extrusive rocks, Snavely and others (1973) proposed a local origin for these basalts from coastal vents separated from the Chief Joseph dike swarm by $500 \mathrm{~km}$. They suggested that the eruptive centers (e.g., Yaquina Head, Cape Foulweather, Cape Lookout, Cape Meares, Cape Falcon, Tillamook Head) overall form a north-trending belt which 
can be divided into three segments (Figure 4).

According to classical, traditional interpretation, volcanic dikes indicate nearby vents. However, Beeson and others (1979b), primarily on the basis of geochemical considerations, have suggested an alternative hypothesis for the origin of the coastal basalts, namely that the coastal basalts are the distal ends of the Columbia River basalt plateau flows that travelled through the topographic low in the ancestral Cascades into western Oregon. In this interpretation, the intrusions are assumed to be the result of interactions of hot, dense basaltic lava with less dense, unconsolidated, water-saturated sediment. It is important for this discussion, therefore, that terms such as "intrusion", "dike", and "sil1" be considered purely descriptive terms of geometry and contact relations without genetic implications.

Models to explain the origin of consanguineous Miocene basalts erupted from vents $500 \mathrm{~km}$ apart require regional processes for magma generation and/or emplacement limited by several constraints: 1) the total volume of basalt $\left(120,000 \mathrm{~km}^{3}\right.$ on the plateau, $500 \mathrm{~km}^{3}$ at the coast) demands a very large magma source; 2) chemical and isotopic data necessitate three distinct parental magmas to produce the three basalt types; 3 ) considerable separation of vent areas erupting virtualiy identical basalts requires rapid rise of the magma without crustal contamination or fractional crystallization; 4) andesite and dacite must be contemporaneousiy erupted along the intervening western Cascade Range;

5) the oceanic crust, underlying the coastal basalts, must be distinguished from the continental crust, through which the plateau basalts probably erupted (Snavely and others, 1973). It is difficult to under- 


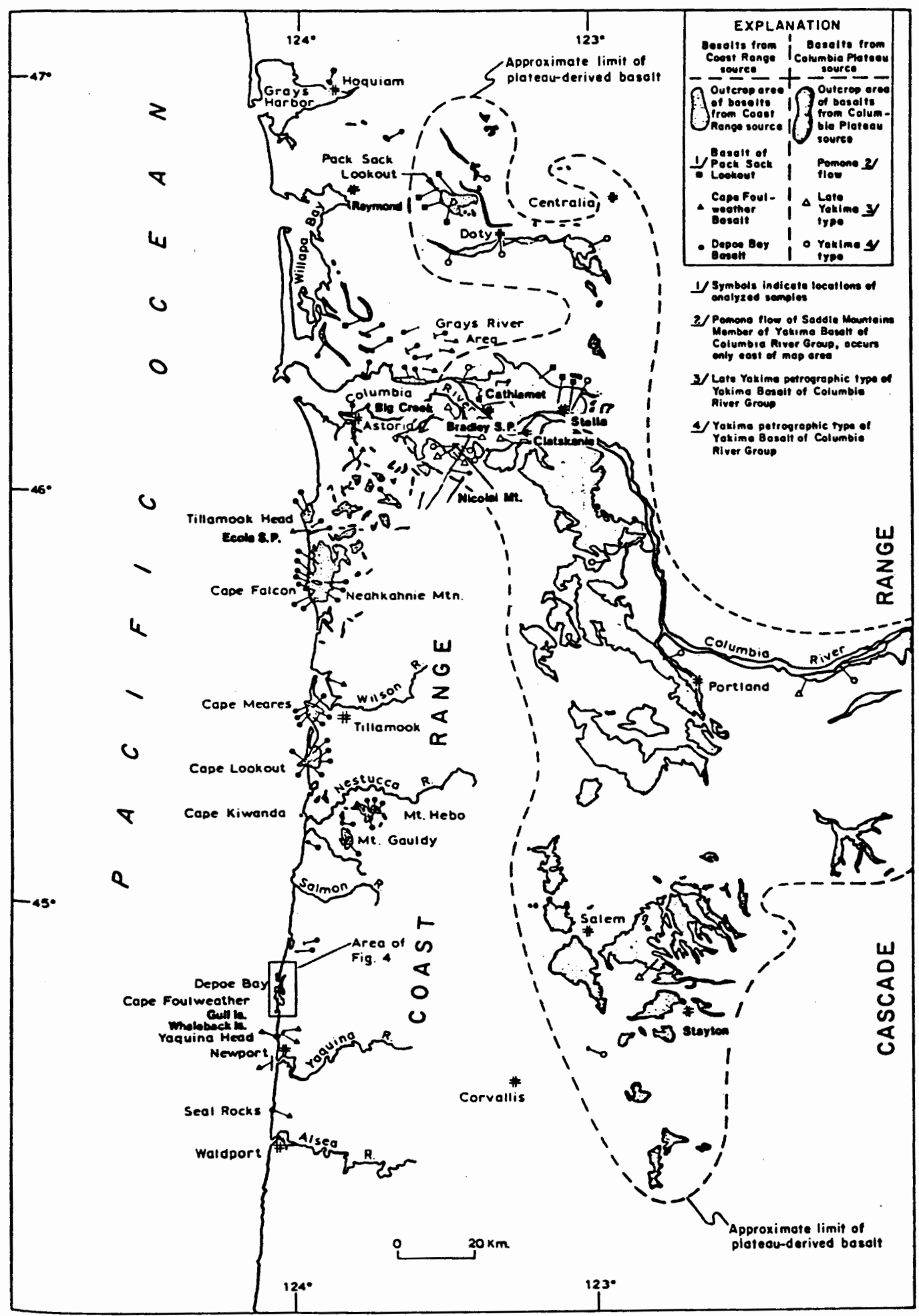

Figure 4. Distribution of coastal basalt features and vent areas. (Modified from Snavely and others, 1973). 
stand how three magmas could maintain their compositional uniformities during migration to vents that are $500 \mathrm{~km}$ apart and erupt with the same stratigraphic sequence and during the same time intervals. Beeson and others (1979b) characterize the petrologic problem:

Thus we are confronted with some rather weighty problems of petrogenesis or subterranean magma transport. Could the upper mantle produce virtually identical sequences of magma in these widely separated and tectonically dissimilar regions and yield them for eruption at the same time? Or could a continuous, homogeneous magma chamber or conduit stretch from eastern Oregon and Washington to the coast, crossing the major northsouth structural zone of the Cascade Range, and erupt identical magmas only at the ends, while magmas of different composition (e.g. andesites in the Cascades and the Prineville chemical type of the Columbia River Basalt Group near Prineville, Oregon) were erupted in between? The inadequacies of these and similar ad hoc hypotheses have prevented a consensus regarding the origin of the coastal Miocene basalts.

No model has been proposed yet that conforms to all the constraints satisfactorily.

In turning to the alternative hypothesis of Beeson and others (1979b), regional petrogenetic problems are exchanged for local mechanical ones. Although instances of plateau basalt invading sediment (lava cross-cutting downward from the surface) are well-documented (Schmincke, 1964, 1967; Swanson and Wright, 1976), the mechanism generating the coherent dikes and sills up to hundreds of meters thick or long seen in the coastal region is not empirically understood; as Beeson and others (1979b) point out, there are no known modern examples to examine for uniformitarianism comparison.

Considerable thicknesses $(550 \mathrm{~m})$ of the Grande Ronde and Wanapum basalts have been followed through the Cascade Range (Beeson and Moran, 1979), into the Portland area (Beeson and others, 1976b), westward to within $25 \mathrm{~km}$ of Astoria, Oregon (Snavely and others, 1973), into the 
Willamette Valley in Oregon between the Cascade and Coast Ranges, and across the present site of the Coast Range in Washington (Snavely and others, 1973). A thickness of more than $400 \mathrm{~m}$ of plateau basalt is exposed along the Columbia River just $40 \mathrm{~km}$ east of the coast (Niem and Van Atta, 1973).

The coastal basalts are found in close proximity to the plateau basalts (Figure 4). Basalt of Pack Sack Lookout crops out within one kilometer of Grande Ronde Basalt east of Pack Sack Lookout, Washington, and elsewhere (e.g., Cathlamet and Stella, Washington) overlies sediments filling channels cut in Grande Ronde Basalt. "Because of the paucity of dikes of Pack Sack composition, a plateau source for some of the Pack Sack basalt cannot be disproved" (Snavely and others, 1973). Of particular note is Snavely and others' (1973) observation:

... dikes of Depoe Bay composition occur near some flow sequences that are composed largely of Yakima-type [Grande Ronde] basalt of plateau origin, such as at Nicolai Mountain, $30 \mathrm{~km}$ east of Astoria. Further work ... is needed in this area in order to differentiate basalts of local source from those that came from the plateau.

The location of some proposed coastal vents are within the known areal extent of plateau basalts. It would seem unreasonable, then, to place an arbitrary westward limit to these fluid plateau basalts which are known to have travelled at least $400 \mathrm{~km}$ from their source. Beeson and others (1979b) note:

It may well be assumed that lava that flowed through the Cascades and into the Portland area, and was able to flow 100 $\mathrm{km}$ south up the ancestral willamette Valley could also have flowed approximately the same distance down-gradient to the ocean. ... The plateau basalts needed to flow only a short distance from the Willamette Valley across the then poorly developed coast Range to reach the coast.

In Oregon particularly, this critical area lying between the coast 
(mapped coastal basalts) and the Willamette Valley (mapped plateau basalts) has not been adequately investigated for basalt occurrences and types.

Erosion of broad and folded hills and the deposition of the detritus in nearby valleys (Tolson, 1976) created a gentle and subdued topography in the Miocene coastal region prior to the entrance of the Columbia River basalt. Late 01 igocene to early Miocene deltas extended the shoreline of Oregon and Washington to at least the present westward extent (Snavely and Wagner, 1963). Water-saturated, low energy sediments abounded in this deltaic and estuarine coastal environment. The coastal basalt dikes and sills mapped within these extensive sedimentary units could have formed as the basalt sank into and rafted the lighter sediments, triggering settling and slumping, or by filling in tension fractures, or by being injected into sedimentary sections adjacent to thick, ponded basalt flow masses.

Thus an alternative solution to the problem of simultaneous extrusion of consanguineous coastal and plateau basalts is to argue that there are only plateau basalts, which flowed westward as far as the coast (Beeson and others, 1979b). The controversy seems to hinge on the coastal dikes and their genetic implications. The dikes may be invasive, similar to those described by Schmincke (1964, 1967) and Swanson and Wright (1976) in the northeast plateau, i.e., dense, subaerial flows that cross-cut downward from the surface into unconsolidated sediments, or the dikes may be the result of upward intrusions from local source areas. 


\section{PURPOSE AND SCOPE}

The purpose of this study was to examine the hypotheses about coastal basalt origin by investigating some of the coastal basalts both geochemically and geophysically. The geochemical analysis of basalt samples using Instrumental Neutron Activation Analys is (INAA) supplements previous data by establishing the chemical types of selected coastal basalts. The combination of chemical type and magnetic polarity, measured with a fluxgate magnetometer, suggests distribution patterns of the flows or groups of flows. Fingerprinting of tholeiitic basalt flows using trace element abundances has become an established technique for tracing individual flows and has been successfully applied to both the plateau and coastal basalts. Measurement of the paleomagnetic direction coupled with chemical or field identification and field relations of basalt flows has yielded a stratigraphic section (Beeson and Moran, 1979; Swanson and others, 1979) to which other incomplete sequences can be correlated.

Geophysical investigations of several isolated linear and circular dikes of coastal basalt detail their subsurface configurations. A Worden gravimeter was employed in traverses across these intrusions, and the models resulting from such geophysical investigations of coastal basalt dikes indicate the depth to which these features could extend. If shallow bottoms for dikes are indicated, origins other than roots-atdepth can be argued for these features. The density difference between the basalt $(2.8 \mathrm{~g} / \mathrm{cc})$ and the sedimentary rock $(2.4 \mathrm{~g} / \mathrm{cc}$ ) (Snavely and Wagner, 1964) provides a contrast adequate for gravimetric measurements. 
The results of this research should add considerably to the existing knowledge of the Miocene tholeitic basalts in Oregon and Washington. Extension of the identification and distribution patterns of these basalt formations is critical to understanding their genesis. Small scale geophysical techniques have not previously been applied to these basalts, so these geophysical results are significant as they are used to indicate both the subterranean extent of the coastal basalt dikes and the applicability of the technique itself to solving the problem of coastal basalt genesis.

\section{GEOGRAPHIC SETTING}

The approximately $500 \mathrm{~km}^{2}$ of northwestern Oregon studied extends from the northwestern flank of the Coast Range to the coast (Figure 5). The elevation of the rolling, hummocky hills that characterize this region generaliy decreases from approximately $375 \mathrm{~m}$ in the east to sea level at the coast. Relief is generally less than $300 \mathrm{~m}$ except where resistant thick accumulations of Tertiary basalts have withstood erosion, such as at Saddle Mountain and Humbug Mountain, $600 \mathrm{~m}$ and $400 \mathrm{~m}$, respectively, higher than the surrounding sedimentary rocks. These less resistant 01 igocene and Miocene sedimentary rocks are weathered and eroded to a subdued, rounded topography that is subject to extensive mass wasting. Rock units are dissected and exposed by the Lewis and Clark River, Youngs River, Klaskanine River, and numerous streams.

The study area lies within Clatsop County and is covered by the following U.S. Geological Survey 15' quadrangles: Astoria, Svensen, Cathlamet, Birkenfield, Saddle Mountain, and Cannon Beach. 


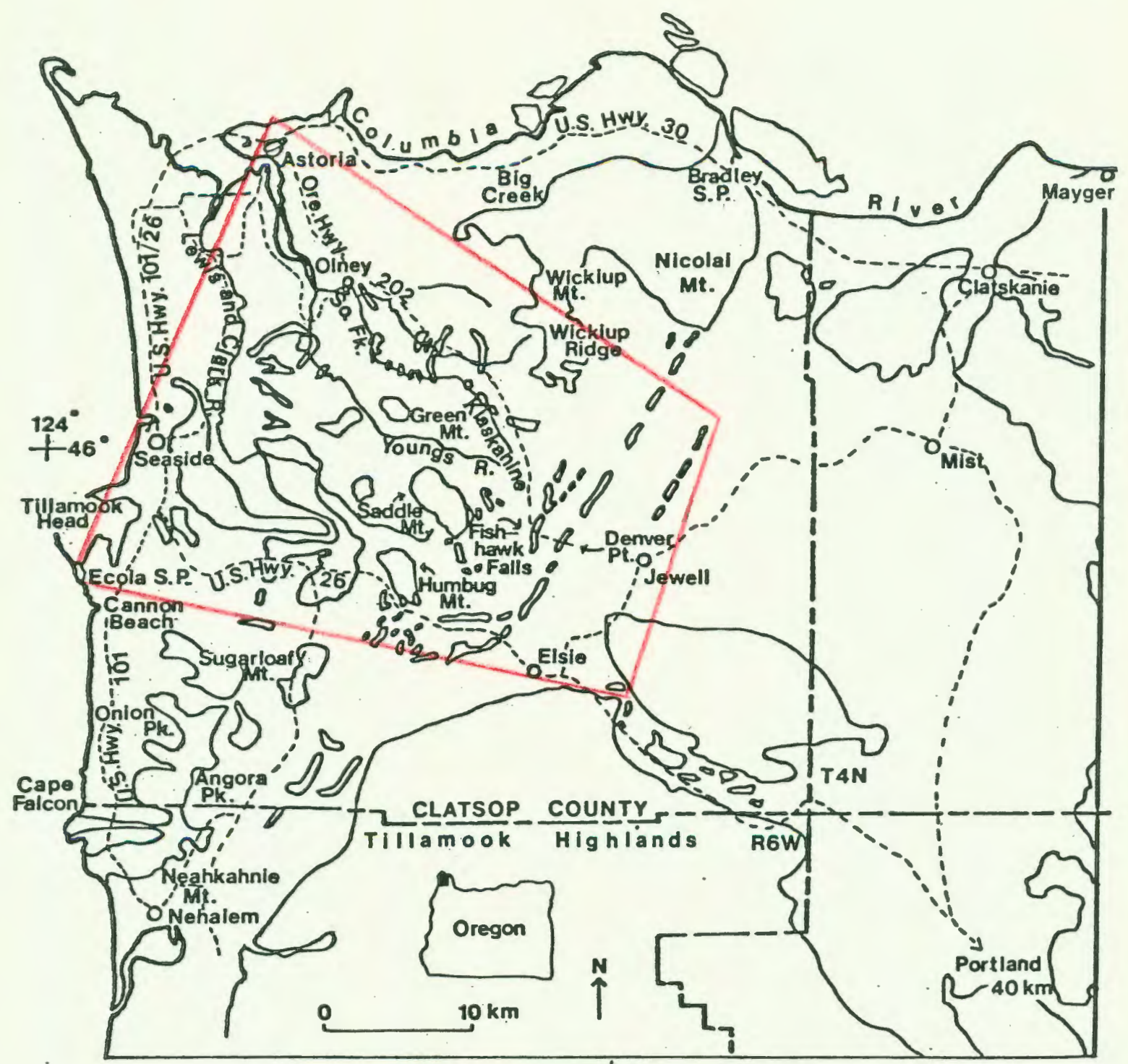

Figure 5. Geographic index map of the study area (outlined in red). (Base map from Wells and Peck, 1961; Schlicker and others, 1972; Beaulieu, 1973).

The climate of the area is generally cool in the summer and mild and wet in the winter. The average annual rainfall may exceed $200 \mathrm{~cm}$, and morning fog is common in the lowlands; the ocean winds contribute significantly to this temperate and moist climate (Tolson, 1976).

While sedimentary rocks are deeply weathered in this humid region, forest growth thrives -- primarily Douglas fir, hemlock, spruce, cedar, 
and alder trees. The thick vegetation makes cross country traverses nearly impossible. Access is provided by U.S. Highway 26 (Sunset Highway) from Portland to Seaside, State Highway 202 (Nehalem High'vay) from Jewell to Astoria, and U.S. Highway 101 (coast highway) from Seaside to Astoria. County roads and numerous logging roads and spurs provide both a network of routes to the interior and roadcut exposures.

\section{PREV IOUS MAPPING}

Regional reconnaissance mapping of northwestern Oregon was first accomplished by Warren and others (1945) for an investigation of oil and gas potential, for which they differentiated between the major Miocene volcanic units on the coast and the surrounding sedimentary rocks. We11s and Peck (1961) began to subdivide the sedimentary units in northwestern Oregon on their Geologic Map of Oregon West of the 121st Meridian, on which Columbia River basalt flows and intrusive units are mapped separately and distinguished from older basalts. Snavely and Wagner (1963), reconstructing the Tertiary geologic history of western Oregon, placed each major sedimentary and volcanic formation within a regional picture organized chronologically. In the following year, Bromery and Snavely published a geologic interpretation for northwestern Oregon based on geophysical data. Schlicker and others (1972) and Beaulieu (1973) mapped the coastal and inland regions, respectively, of Tillamook and Clatsop Counties with an environmental hazards perspective; Schlicker and others (1973) similarly covered Lincoln County in a separate bulletin. Maps produced by these latter investigations present increased detail due in part to coverage of smaller areas and to 
improved access; however, these works are still essentially of a regional nature. Area-specific theses and studies provide the most comprehensive pictures. Lowry and Baldwin (1952) studied the Tower Columbia River valley; Newton evaluated oil and gas potential for the lower Columbia and Willamette Valleys (1969) and upper Nehalem Valley (with Van Atta, 1976); Dodds (1963) mapped the west half of the Svensen quadrangle and studied the Astoria Formation; students under Dr. A.R. Niem, Oregon State University, have collectively mapped and studied a significant portion of northwest Oregon and of the area investigated in this report (including Tolson - Youngs River Falls area - 1976; Nelson Astoria area - 1977; Penoyer - Saddle Mountain area - 1977). A field guide through the northwestern Coast Range to the coast was provided by Niem and Van Atta (1973).

Snavely and others (1973) named and described the three Miocene coastal basalt units distinguished on the basis of lithology and geochemistry in northwestern Oregon and southwestern Washington, and correlated these units to three Columbia River basalt plateau units. Their conclusions and speculations on the local origin of these basalts prompted Beeson and others (1979b) to propose as an alternative hypothesis that the basalts were actually the distal ends of Columbia River basalt flows originating east in the Columbia Plateau. These two papers, in their differing interpretations of the coastal basalts, form the basis for this study.

\section{FIELD WORK}

Reconnaissance field work was conducted during spring weekends in 
1979. Geophysical field work spanned the three summer months of 1979; geochemical and magnetic sampling occupied most weekends in the spring of 1980. The summer, fall, winter, and spring of 1979-1980 were spent reducing and analyzing the geophysical data; the geochemical data were generated and analyzed in the summer of 1980. Investigative methods and equipment are discussed in the geochemistry and geophysics sections and in Appendix A. 
WESTERN OREGON GEOLOGY

REGIONAL GEOLOGIC HISTORY OF WESTERN OREGON

The $7500 \mathrm{~m}$ of Cenozoic rocks in western Oregon (Snavely and Wagner, 1964) disclose alternating periods of marine sedimentation and volcanism that record the episodic interactions of the Pacific and North American plates (Figure 6). 01dest in this sequence are the early Eocene lower Tillamook volcanics, the basement rock in northwestern Oregon, equivalent to the Siletz River volcanics of the central coast Range. This 3000-6100 m thick (Newton, 1969) sequence of tholeiitic basalt submarine pillow lavas and breccias is thought to be oceanic crust formed at a spreading ridge and "accreted onto the continental margin at the time when subduction jumped from east of the coast Range to the present continental margin" (Snavely and others, 1980a). The westward jump may have been caused by the jamming of the former subduction zone by an aseismic ridge (Simpson and Cox, 1977). The oceanic basalts are overlain by seamounts and oceanic islands (Newton, 1969; Snavely and others, 1980a) differentiated along the Hawaiian trend (Simpson and Cox, 1977). A deep marginal fore arc basin, which formed east of this new subduction zone and atop the newly accreted Eocene crust, extended under the present site of the Cascades (Snavely and Wagner, 1963).

By mid-Eocene, the southern end of the marginal basin had been uplifted; the deep part of the basin remained in northern Oregon. While 


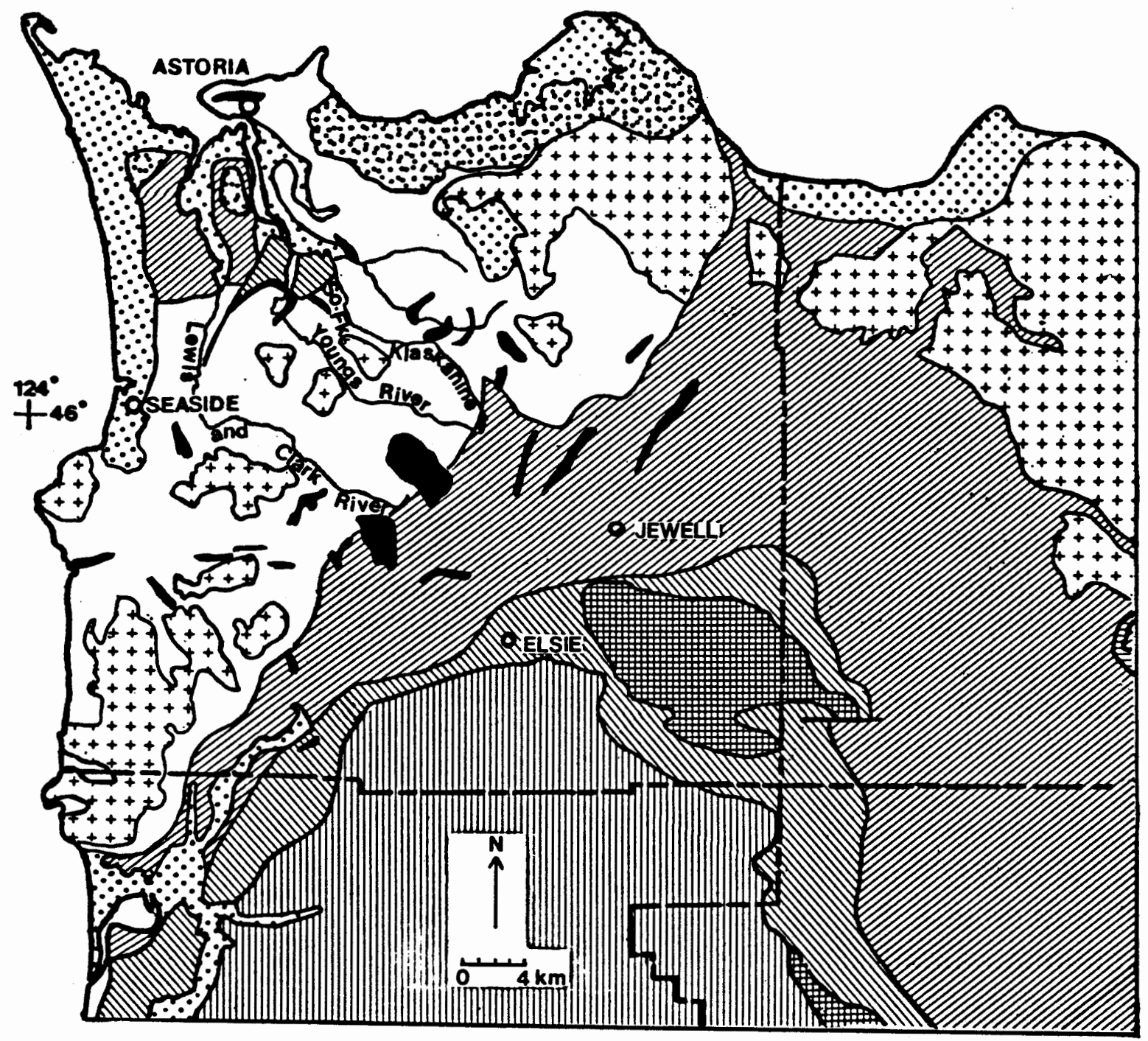

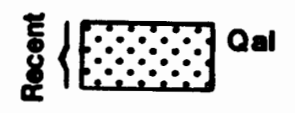

alluvium

dune sands

landslide dobris

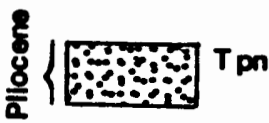

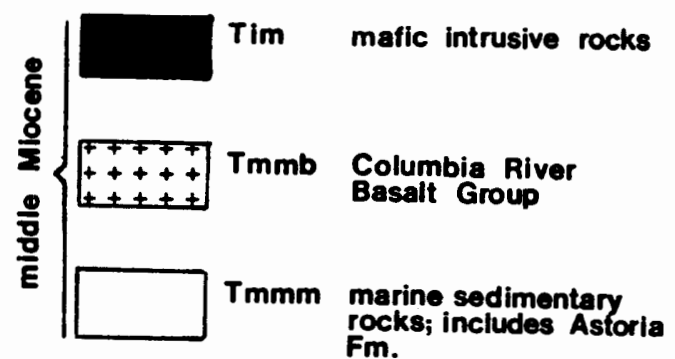

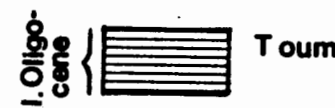

marine sedimentary rocks: includes Scappoose Fm.
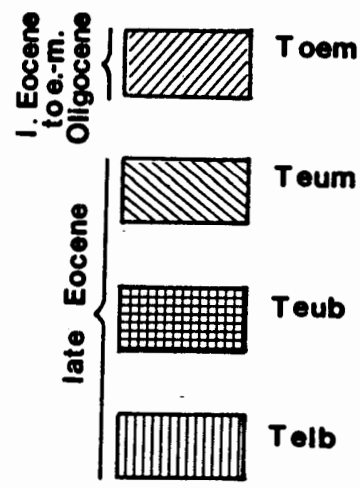

marine sedimentary rocks; includes Keasey and Pittsburgh Bluff Fms.

marine sedimentary rocks; includes Cowlitz Fm.

basalt; includes Goble volcanics

basalt; includes Tillamook Volcanic Series

Figure 6. Regional geologic map. (From Wells and Peck, 1961). 
erosion of the Klamath Mountains to the south filled the southern portion of the basin with considerable terrigenous detritus, volcanism continued further north in the Tillamook Highlands area (Snavely and Wagner, 1963).

A transform fault between the Pacific and North American plates, inferred for late middle to early late Eocene, resulted in $200 \mathrm{~km}$ of dextral slip. Subsequent underthrusting, perhaps a period of imbricate thrusting by the downbending oceanic plate, west of this fault boundary promoted regional uplift and erosion and a concomitant angular unconformity at the base of the upper Eocene (Kulm and Fowler, 1974; Snavely and others, 1980a,b). By late Eocene, local uplift and renewed volcanism had subdivided the regional basin into several separate shelf depositional basins; the sea withdrew to the northwest. In the northeast Coast Range area, the Goble volcanics were erupted into the structural downwarp near the present Columbia River (Newton, 1969), where they are interbedded with the marine sedimentary rocks of the Cowlitz Formation. Late Eocene may have been the beginning of the $50^{\circ}-70^{\circ}$ clockwise rotation of coastal Eocene rocks deduced by Simpson and Cox (1977) and postulated to be due to back arc spreading and/or changes in plate motion.

Pyroclastic volcanism to the east in the ancestral Cascade Range contributed considerable amounts of ash to the 0ligocene marine deposits. Sedimentation continued around the Columbia River on the northeastern side of the Tillamook Highlands and throughout the northern Willamette Valley (Snavely and Wagner, 1963), producing the Keasey, Pittsburgh Bluff, and Scappoose Formations. By late 0ligocene, the area from Portland to Astoria was a large marine embayment and the continent- 
al shelf (fore arc basin) extended from the Scappoose outcrops on the east $80 \mathrm{~km}$ to the west (Tolson, 1976). West-flowing streams began to drain through the present site of the Coast Range, forming westprograding deltas at their outlets, as the Pittsburgh Bluff, Scappoose, and Yaquina Formations suggest (Niem and Van Atta, 1973). Late 01igocene was characterized by broad uplift (Snavely and Wagner, 1963), westward recession of the Tertiary seas, westward shift of marine deposition (Kulm and Fowler, 1974), and minor deformation of rocks in the northern Coast Range (Newton and Van Atta, 1976).

During the early Miocene, deposition continued in those basins that had received late 01 igocene sediments. The late early Miocene saw broad uplift likely due to shallow imbricate thrusting of the abyssal deposits on the Juan de Fuca plate as it moved under the American plate (Kulm and Fowler, 1974; Seely and others, 1974). By early mid-Miocene, the older Tertiary strata were folded and faulted along a northeast structural trend in Oregon; the northeast regime prevailed in western Oregon into late Miocene (Beeson and others, 1979a). Shallow marine bays transgressed eastward along structural downwarps such as the west-trending ancestral lower Columbia River (south of the present Columbia River)-upper Nehalem basin and Grays Harbor basin (Snavely and Wagner, 1963). Overturned folds and slump structures in the Miocene Astoria Formation, deformed during deposition, indicate that the deepest part of this depositional basin remained in northern Oregon and lay west of the present coastline (Snavely and Wagner, 1963), where it has since remained. Most of the Coast Range province had emerged above sea level by mid-Miocene (Newton and Van Atta, 1976). 
Large sandstone deltas existed just east of Seaside-Astoria and Yaquina and prograded seaward. The Astoria Formation, found only on the northwestern side of the Coast Range in a series of marine embayments, formed in a deltaic and shallow marine environment (Niem and Van Atta, 1973). The Astoria Formation filled the upper continental slope basin and appears to have had its main depositional locus in the Angora Peak-Neahkahnie Mountain area (Tolson, 1976).

The Astoria delta was undoubtedly the mouth of the Columbia River because boulders within the Astoria had their origins in the Cascades, eastern Oregon, Montana, etc. (Tolson, 1976) and required the volume and pathway of the Columbia for deliverance at the Pacific Ocean. The Astoria Formation shows a westerly paleoslope (Tolson, 1976). The ancestral river depositing the Yaquina delta probably came through the Cascades also, as the Yaquina Formation contains andesite and dacite clasts (Snavely and others, 1980a) and is $600 \mathrm{~m}$ thick (Schlicker and others, 1973).

In the mid-Miocene, the plateau flood basalts spilled down the lower Columbia River downwarp, spreading south in the Willamette Valley and north into the Grays Harbor basin. One might conjecture that the basalts also crossed a low pass and flowed down the valley of the river supplying the Yaquina delta. The flows sought the lowest areas: pillow lavas and breccia record where the basalts entered a wet environment; elsewhere, they onlapped Tertiary highs. They overlie older formations from the Goble to the Astoria with a slight angular unconformity (Newton, 1969), testifying to previous subaerial erosion and deformation at the contact and smoothing the topography with their upper surfaces. 
Each flow likely displaced a stream, so subsequent flows came down valleys marginal to earlier flows. In the lower Columbia River Valley, apparently the Columbia River itself reestablished its valley at the margin of the Columbia River basalt (Lowry and Baldwin, 1952). Due to fluctuations of the Miocene shoreline, subaerial flows interfingered with nearshore marine and nonmarine sands and siltstones just east of Astoria (Lowry and Baldwin, 1952; Snavely and Wagner, 1963; Newton, 1969). Nonmarine mid-Miocene to early Pliocene sedimentary rocks are found in the downwarped ancestral lower Columbia River area (Hells and Peck, 1961; Dodds, 1963; Snavely and Wagner, 1963; Schlicker and others, 1972; Niem and Van Atta, 1973).

Any local eruptions of coastal basalt would have had to occur during this same time. If so, the north-trending group of vents near the shoreline erupted thick accumulations of basalt which formed local small subaerial islands. Snavely and others (1980b) suggest that the magma rose along zones of tensional rifting, but that underthrusting may have occurred during long time intervals between tension-related igneous events.

Following the Miocene basalts (about 10 my ago), a major episode of underthrusting, regional uplift, and erosion resulted in an unconformity at the base of the upper Miocene. By Pliocene, the sea had retreated to approximately its present position; marine deposition in northwest Oregon for this time was very limited, and subaerial erosion predominated. Pliocene Troutdale Formation river gravels were deposited in restricted areas along the lower Columbia River as far west as the Astoria area (Niem and Van Atta, 1973). Episodic downwarping and sedi- 
mentation continued to the Pleistocene as the axes of the basin and of deformation shifted westward (Silver, 1972; Snavely and others, 1980a).

Present elevation of the Troutdale Formation gravels in Astoria indicates at least $75 \mathrm{~m}$ of uplift since Pliocene deposition (Schlicker and others, 1972). Pleistocene marine terrace gravels and sands also mark changes of sea level and record continuing uplift during the late Cenozoic (Newton, 1969). Alluvium and unconsolidated deposits occur on both the wave cut and river terraces (Niem and Van Atta, 1973). The Columbia River continues to contribute clastic debris to the coastal plains; an arcuate coastline extends from Seaside to the Columbia River mouth covered by up to $50 \mathrm{~m}$ of post-glacial sands carried by the Columbia and redistributed by the ocean currents over the shallow shelf. The late Cenozoic, then, saw considerable continental accretion off Oregon, which was accelerated along the northern Oregon coast where the Astoria fan deposits are the thickest (Kulm and Fowler, 1974). Accretion is explained by repeated underthrusting of the Pacific plate under the North American plate. Such compressional thrusting results in regional uplift and compaction, while accretion results from such an operation over time (Seely and others, 1974). The structure of the outer continental shelf and upper slope is an imbricate set of landward (eastward)-dipping slices which together form a melange wedge (Snavely and others, 1980b).

\section{DISTRIBUTION OF MIOCENE BASALT IN WESTERN OREGON}

The Columbia River Basalt Group stratigraphy in western Jregon is presented in Figure 7. As the geographic extent of basalt units gener- 


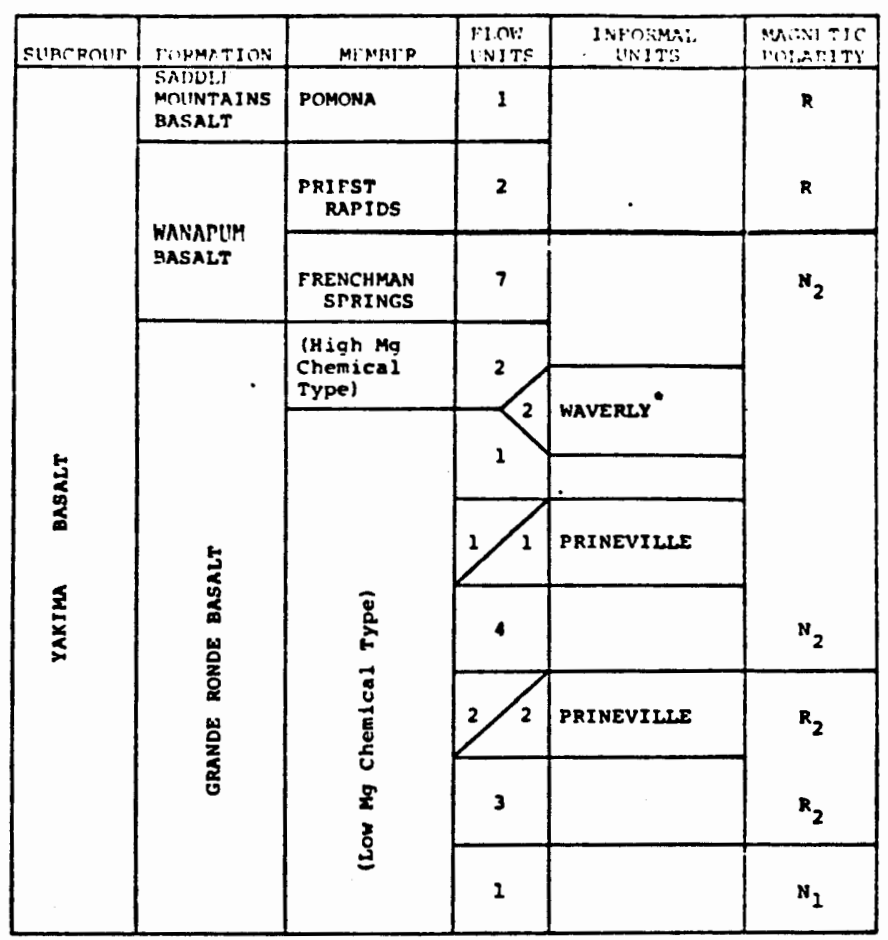

Figure 7. Stratigraphy of Columbia River Basalt Group in western Oregon. Informal units have limited areal extent. (From Beeson and Moran, 1979).

ally decreases upsection (Wright and others, 1973), the Grande Ronde Basalt is the most widespread, the most voluminous $\left(150,000 \mathrm{~km}^{3}\right)$ (Swanson and Wright, 1976), and the oldest of the Yakima basalts (Waters, 1961). It has been dated from 16.5-14.0 my old (Holmgren, 1970; Watkins and Baksi, 1973) and includes, in western Oregon, the younger three of its four known magnetostratigraphic intervals. Subdivision into two members is based on magnesium content -- the "high Mg" member (upper two flows in western Oregon) is younger than the "low Mg" member (11 flows in western Oregon) (Nathan and Fruchter, 1974). There are three distinct Grande Ronde flow units in western Oregon: the reversed polarized low $\mathrm{Mg}$, the normally polarized low $\mathrm{Mg}$, and the normally polarized high Mg. 
Both the high Mg and low Mg Grande Ronde basalt members are recognized in western Oregon as far south as Stayton in the Willamette Valley (Beeson and others, 1976b,c; Norman, 1980) and as far west as the Nicolai Mountain area on the lower Columbia River (Snavely and others, 1973) (Figure 4). Grande Ronde plateau basalt noted at Clatskanie and Alder Bluff, 50 and $60 \mathrm{~km}$ east of Astoria along the lower Columbia River, flowed subaerially as far as Big Creek, $25 \mathrm{~km}$ east of Astoria (Niem and Van Atta, 1973; Snavely and others, 1973).

Along the lower Columbia River, $30 \mathrm{~km}$ east of Astoria, dikes of Depoe Bay basalt occur near some plateau Grande Ronde flows (Nicolai Mountain). Although Snavely and others (1973) do not distinguish high and low Mg members of the Depoe Bay Basalt, their chemical data (for which paleomagnetic measurements are lacking) indicate that both are present within, north, and south of the study area.

The Depoe Bay Basalt, like its equivalent Grande Ronde Basalt, is the 0ldest, most voluminous, and most widespread of the coastal basalts (Snavely and others, 1980a) although, as Snavely and others (1973) point out, plateau basalts are more extensive in northwestern Oregon and southwestern Washington than are coastal basalts. The southernmost extent of the Depoe Bay Basalt is a submarine linear ridge extending five kilometers south of Whaleback and Gull Islands, where it crops out. Although $15 \mathrm{~m}$ of Depoe Bay Basalt is also found offshore $17.6 \mathrm{~km}$ west of Depoe Bay (in the Standard-Union Nautilus well), the lavas are probably restricted to near the present coastline (Snavely and others, 1973).

Depoe Bay basalt occurs along the coast as far north as Hoquiam, Washington; outcrops are also found extending inland northeast from 
Cape Falcon. Snavely and others (1973) consider this 200+ km 1ong outcrop pattern of intrusions to mark the belt along which the Depoe Bay basalt was extruded. The basalt intrudes and/or unconformably overlies the Astoria Formation and late 01 igocene to middle Miocene siltstones and sandstones. Prominent Depoe Bay headlands include Mt. Gauldy, Mt. Hebo, Cape Lookout, Cape Meares, Cape Falcon, and Tillamook Head (Snavely and others, 1980a).

The Depoe Bay and Grande Ronde flows all exhibit remarkable uniformity (Snavely and others, 1973) despite their considerable lateral extents, and cannot be distinguished from each other in the field. They can be distinguished from the other two chemical types in western Oregon by their higher content of $\mathrm{SiO}_{2}$, lower total iron, and lower total $\mathrm{TiO}_{2}$.

The Wanapum Basalt, dated from 14.5-13.6 my old (Watkins and Baksi, 1971), is represented in western Oregon by two of its four recognized members: the Frenchman Springs and Priest Rapids. The 3-5,000 $\mathrm{km}^{3}$ Frenchman Springs Member is the more extensive (Swanson and Wright, 1976) and has been subdivided into three units, in order of decreasing age, the Ginkgo, Sand Hollow, and Sentinel Gap. These three normally polarized units can be recognized by both lithology and trace element concentrations. The Priest Rapids basalt has been found in only limited extent in western Oregon (Beeson and Moran, 1979). The Frenchman Springs Member has been located south in the Willamette Valley as far as Stayton (Beeson and others, 1976b; Norman, 1980) and west as far as Bradley State Park (Kienle, 1971) and Clatskanie (Snavely and others, 1973) (Figure 4). 
The Cape Foulweather Basalt is correlative with the Frenchman Springs member; they exhibit identical and relatively uniform chemical compositions (Snavely and others, 1973; McDouga11, 1976). Cape Foulweather Basalt crops out from Seal Rocks, Oregon, not only the southernmost exposure of the coastal basalts but also of the Yaquina Formation (Snavely and others, 1980a), north to the Grays River area of Washington. It is found in the Yaquina and Astoria Formations north and east of Yaquina Head (considered a vent by Snavely and others (1973)), and cuts Miocene and 01 igocene sedimentary rocks east of the coast between Cape Foulweather and Newport (Snavely and others, 1973, 1980a). A submerged subaerial Cape Foulweather flow extends south of Yaquina Head for $13 \mathrm{~km}$; the Cape Foulweather Basalt does not reach the Standard-Union Nautilus well offshore. Cape Foulweather dikes reportedly cut Depoe Bay sills at Ecola State Park and to the east (Snavely and others, 1973; Tolson, 1976; Penoyer, 1977).

After extrusion of the Frenchman Springs basalt, either Cascade uplift, plateau subsidence, northeast-trending folding, or dwindling volumes of lava prevented most later flows from spreading out over large areas (Beeson and others, 1979a). Only the Pomona flow of the Saddle Mountains Basalt has been found west of the Cascades, although its route to the west has yet to be determined as the unit has not been found between the Plateau and Cathlamet, Washington. The Saddle Mountains Basalt, much less than one percent of the total volume of Columbia River basalt, was erupted between 13.5-6 my ago (Atlantic Richfield Hanford Co., 1976; McKee and others, 1977) and encompasses a period of waning volcanism, accelerated folding, canyon cutting, and development 
of thick but local sedimentary deposits between flows (Swanson and others, 1979). The chemically and lithologically distinct Pomona flow, described by Schmincke (1964) and dated at 12 my by McKee and others (1977), occurs commonly in structural basins and as intracanyon flows in western Oregon. Despite a volume of $700 \mathrm{~km}^{3}$, approximately 45 times that of a single Grande Ronde flow (Swanson and Wright, 1978), the Pomona flow is relatively homogeneous (Schmincke, 1964).

The basalt of Pack Sack Lookout is one flow (Snavely and others, 1973; Hi11, 1975), correlative in every respect with the Pomona flow; Kienle (1971) found the coastal unit to be chemically, morphologically, petrographically, stratigraphically, and paleomagnetically identical to the plateau Pomona. Basalt of Pack Sack Lookout occurs atop a sequence of Miocene basalt flows near Stella and Cathlamet, Washington (Snavely and others, 1973), near which it is found in channels cut in the older Grande Ronde Basalt (Niem and Van Atta, 1973; Snavely and others, 1973) (Figure 4). In the Pack Sack Lookout area, the coastal basalt is separated from an underiying Grande Ronde flow by about $1500 \mathrm{~m}$ of sedimentary rock (Snavely and others, 1973). Pack Sack Lookout basalt crops out $15 \mathrm{~km}$ northeast of Raymond, Washington, and also about $60 \mathrm{~km}$ south of Pack Sack Lookout along the Washington side of the lower Columbia River (Snavely and others, 1973). Since no local sources and very few dikes are found for Pack Sack basalt, Kienle (1971) considers the isolated exposures of Pack Sack Lookout basalt to be remnants of a once continuous Pomona flow; Snavely and others (1973) consider the absence of outcrops in the Willamette Valley and Puget lowland to be significant, indicative of possible local origin for the coastal basalt. 
Beeson and others (1979b) noted the close correspondence of coastal basalt and post-Eocene sedimentary rocks in western Oregon and Washington (Figure 8) as mapped by Schlicker and others (1972), Beaulieu (1973), and Snavely and others (1973). Everywhere except at Mt. Hebo, the coastal basalts seem to occur only in post-Eocene sedimentary rocks and around the perimeter of the Eocene volcanic highlands (e.g., the Tillamook Highlands). "0lder or lithified sedimentary rocks are seldom associated with these [coastal basalt] intrusives, despite the extensive occurrence of Eocene formations" (Beeson and others, 1979b).

\section{MODE OF OCCURRENCE OF MIOCENE BASALT IN WESTERN OREGON}

Intrusions of surficial basalt flows downward into sediments are grouped by Schmincke $(1964,1967)$ according to their gross structures: 1) fragmental intrusions (breccias or peperites), in which the sediment is usually fine-grained and unconsolidated (e.g., diatomite mud or vitric ash), and 2) smooth, sill-like invasions along bedding planes or injections of lava as tongues or globular masses into sediment, usually a fluvial sandstone, which has better defined bedding and greater strength. For the first case, he described how the "light, uncompacted sediments offer little resistance to the heavy, fluid lava" which can spread downward, "unguided by well defined bedding planes" and fragment and/or intermix with the sediments (Schmincke, 1964):

The hydrostatic pressure of liquid lava and of the still mobile inter-mixture of lava and sediment was so high in places that the lava intruded upward through its thin cover of sediments, exploded into the sediments, and congealed as peperite "dikes".

Schmincke (1964) summarized: 


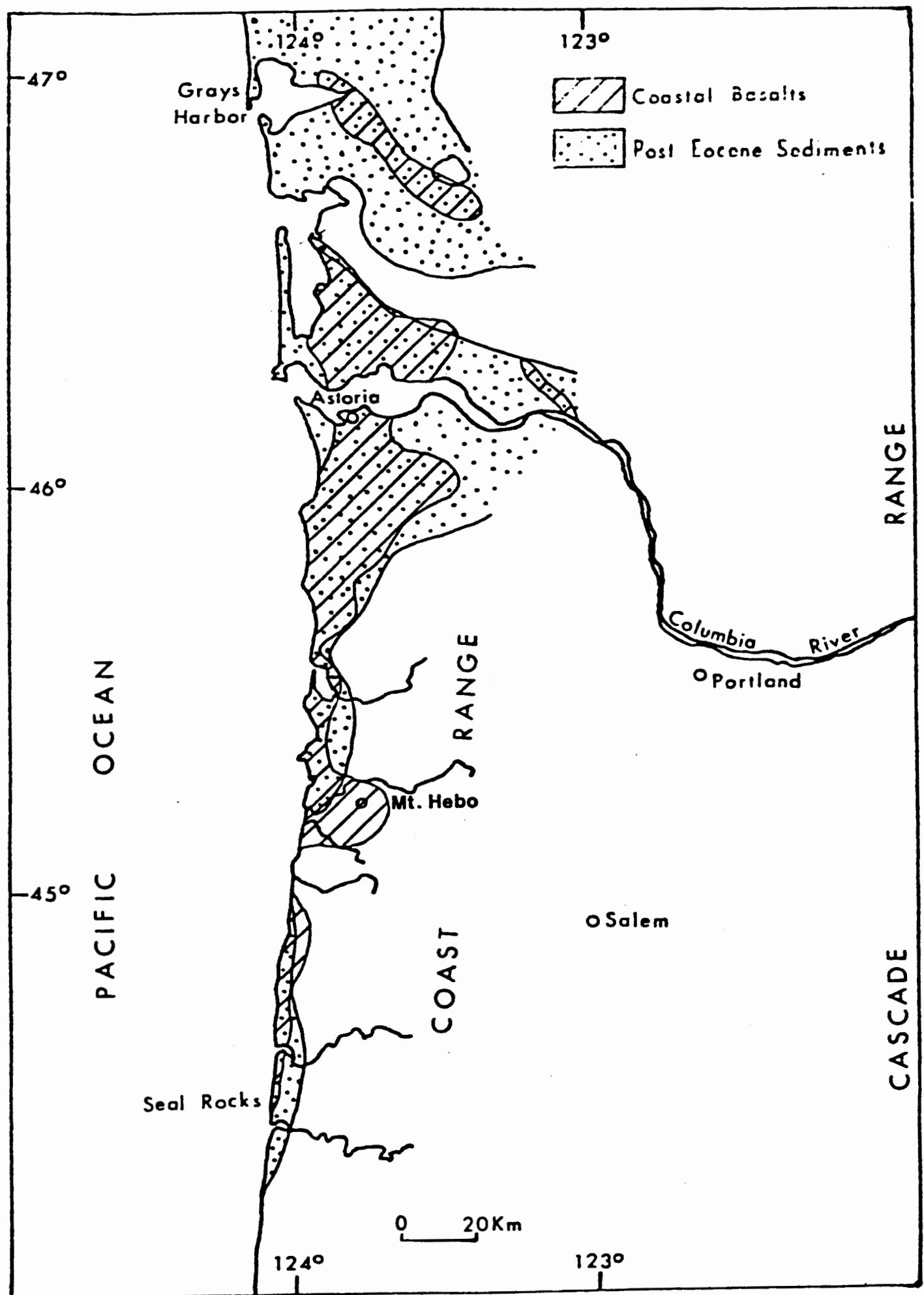

Figure 8. Areal distribution of coastal basalts and post-Eocene sediments in western Washington and Oregon. (Modified from Snavely and others, 1973). (From Beeson and others, 1979b). 
A basalt flow may advance over a sedimentary layer without much mechanical deformation, or it may form a peperite layer between the sediment and the bulk of the overiying lava. Basalt may invade downward into the sediments at various levels in a smooth sill-like fashion with remarkably little deformation of the sediments, or it may occur in irregular forms, in "dikes", lobes, or tongues of solid lava, as autobreccia, or peperite. Sediment layers may be gently lifted to the top of the basalt, or may be fragmented, bulldozed aside, and intermixed with the basalt. ... Many of these features indicate that the invading basalt lava must have been very fluid.

Dynamic basalt/sediment interactions on the Plateau have been described by other workers (Waters in Schmincke, 1964; Swanson, 1967; Swanson and Wright, 1976). Swanson and Wright (1976) "estimate that more than half of the observed contacts between basalt and sedimentary rocks on the Columbia Plateau are invasive":

How are such contacts interpreted? Do they signify "normal" intrusive relations, in which basaltic magma never reached the surface before solidifying as in classic dikes and sills, or are they formed as lava flows burrow into unconsolidated sediments accumulating on the ground surface (invasive flows of Byerly and Swanson, 1978)? Both processes produce similar results.

\section{Byerly and Swanson (1978) found:}

...2many 5-120 m thick basalt bodies, some covering hundreds of $\mathrm{km}^{2}$, occur in sil1-1ike relation to interbedded sedimentary rocks ... Tops of these bodies have thick glass selvedges, generally are nearly planar, and contain few vesicles. Locally, thin dikes and sills spout from the top and intrude the host sedimentary rock. All sill-like bodies intrude 3-20 m thick sedimentary deposits; none cuts an older flow, nor have any feeder dikes been found. ... Exposures show lateral gradation over hundreds to thousands of meters from surface flows through pillow-hyaloclastite complexes and peperites into invasive flows. ... Invasive flows may be found in any basaltic province where flows enter areas in which fine-grained sediments are accumulating.

Swanson and Wright (1976) write that:

... the key to proper interpretation lies in the stratigraphy. If the basalt is at its proper stratigraphic position relative to overlying flows, it almost certainly was a flow 
that invaded sediments at the ground surface. This is because thin sedimentary deposits, generally less than $10 \mathrm{~m}$ thick on the plateau, are light and hence exert little confining pressure; vesiculating magma rising and encountering such sediments would certainly blast through rather than spreading laterally into them. ... These conclusions are significant, because they show that invasive contacts provide insufficient, in fact totally misleading, evidence for the former presence of magma beneath the area.

A pillow-palagonite complex at the base of a basalt flow indicates flowage into water. Schmincke (1964) describes how such sediments, in the absence of water,

may be baked as much as 10 feet $(3 \mathrm{~m})$ (general1y about $1 \mathrm{~m}$ ) below the flow. Baked clay-rich rocks are brittle, and many show shrinkage jointing characterized by small polygonal columns generally less than $2 \mathrm{~cm}$ in diameter. Some baked sediments are oxidized to brick red at the contact, but most are blue-gray.

Perfect columnar jointing in sedimentary layers adjacent to basalt flows and intrusions is also noted by Lefebvre (1970): "In all cases, the joints have been perpendicular to the contact."

Reconstructions of the Miocene coastal environment in the Astoria and Yaquina areas gleaned from the sedimentary record (Niem and Van Atta, 1973; Tolson, 1976; Murphy and Niem, 1980) have detailed deltaic environments, which would include networks of distributary channels and low energy areas (marshes, lagoons, etc.). Although the coastal basaltsediment interactions occurred on a much larger scale than those described by Schmincke $(1964,1967)$ from the plateau, the similarities between the types of occurrences from the plateau margins and the coastal regions suggest similar processes were operating (Beeson and others, 1979b):

The Columbia River basalt flows, upon encountering the sediment of the coastal region, could have interacted with the sediments in a variety of ways similar to those described by 
Schmincke (1964). ... Basaltic lava would have ponded in local topographic lows such as coastal marshes, inlets, and deeper channels, as may have happened at Neahkahnie Mountain. Accumulating ponded basalt would overload and displace the underlying sediments, with accompanying sediment deformation and sliding. Tensional zones associated with deformation and sliding of the sediments adjacent to ponded basalt would be injected locally with basaltic dikes. This injection process would be aided if slide masses carried the chilled basalt margins with them, thereby exposing liquid basalt to the tensional zones. Shrinkage joints in the chilled margins of ponded basalt would also be injected locally with liquid basalt from the interiors, as may have occurred at Saddle Mountain ... (Baldwin, 1952). The overloading of unconsolidated sediments with basaltic lava would also tend to liquefy water-saturated layers between less permeable, more cohesive layers, thereby producing clastic dikes, common in the sedimentary rocks of the area.

Both the Depoe Bay and Cape Foulweather basalts exhibit basalt breccia, breccia dikes, and peperites resulting from intrusion of magma into water-saturated sediments with consequent rapid quenching, steam explosions, and penecontemporaneous deformation. For example, Niem and Van Atta (1973) and Niem and Cressy (1973) find locally altered and brecciated basalt contacts "suggesting that the igneous intrusions displaced still plastic or semi-lithified water-saturated sediments, throwing them into huge folds and jumbled angular blocks of sediment in a sandstone matrix." Irregular brecciated apophyses associated with penecontemporaneously folded sediments are particularly evident at the upper portion of the Tillamook Head sill at Indian Beach in Ecola State Park, where $\mathrm{K} / \mathrm{Ar}$ and foraminifera dating confirm that the intrusion took place soon after deposition of the sediments (Niem and Cressy, 1973). Many dikes, sills, and irregular intrusions could also record the passive basalt-sediment interactions where a flow invaded the underlying sediments without significant sediment deformation.

Contacts in the study area, where observed, tend to be irregular 
but very sharp, and oxidized baking, if present, is usually minimal; well-indurated baked and bleached sedimentary zones seem more common. Adjacent sediments may be jointed parallel to the basalt contact, to which some jointing in the basalt is also parallel, suggesting that they were heated by the intrusion and cooled similarly to the intrusion itself (e.g., at VP-26 and VP-30, Figure 9). Disruption is usually more evident in the basalt than in the sediments; brecciated and/or highly weathered contacts most often involve only the basalt (e.g., at $V P-6, V P-29, V P-21, V P-24, V P-32 . V P-2$, Figure 9). At the Youngs River Falls quarry, sheared $(2-5 \mathrm{~cm}$ wide zone) and then brecciated $(15-20 \mathrm{~cm}$ wide zone) basalt is adjacent to baked, intact, well-indurated sedimentary rock. No vesicular basalt was noted except in the breccia fragments on Saddle Mountain.

Coastal basalts do not conform strictly to descriptions of invasive flows in that Cape Foulweather dikes are observed to cut Depoe Bay sills (Niem and Van Atta, 1973; Snavely and others, 1973; Tolson, 1976; Penoyer, 1977), whereas on the plateau, invasive basalts do not intrude other basalt flows (Swanson and Wright, 1976). Swanson and Wright (1976) also stress the significance of stratigraphy. Stratigraphy of the coastal basalts is hampered by the infrequency with which they contact each other; outcrops tend to be isolated and a regional detailed sedimentary stratigraphy is still being worked out and correlated. 


\section{GEOCHEMISTRY}

\section{INTRODUCTION}

The Columbia River basalt flows are a chemically coherent and distinct group within which variations of major and minor elements serve to distinguish individual flows. Hill (1975) could find "no other basalts ... in the literature with chemical compositions as similar to these Miocene plateau basalts as were the [Miocene] coastal basalts." The Columbia River basalt flows as a whole resemble each other more than they do other basalt units. Studies to examine variation of geochemistry and petrography laterally within flows found no significant variation with distance (Atlantic Richfield Hanford Co., 1976).

Geochemistry has been critical for identification and correlation of Columbia River basalt flows. After Waters (1961) first recognized two distinct chemical types based on petrography and stratigraphy, Wright and others (1973) defined 11 "chemical types" among the Columbia River basalt flows based on major elements and demonstrated an overall relationship between chemical type and stratigraphic position. Using chemical type, lithology, and stratigraphy, they were able to group like flows and to correlate flows across the plateau. Osawa and Goles (1970) proposed using trace element abundances to characterize individual flows and "demonstrated the applicability of Neutron Activation Analysis technology for identifying trace elements" (Atlantic Richfield Hanford Co., 1976). Nathan and Fruchter (1974) established that most of the flow 
units have a unique identifying "fingerprint" based on the individual abundances of major and trace elements. The application of trace elements to the study of basalts has gained widespread acceptance among workers in both the plateau (Atlantic Richfield Hanford Co., 1976; Beeson and others, 1976a,b,c; McDouga 11, 1976; Beeson and Moran, 1979) and coast (Hill, 1975). Kienle (1971) and Beeson and others (1976a) found major and trace elements, respectively, a feasible way of correlating western Oregon flows with those of the plateau.

Magnetic polarities are particularly useful in distinguishing different groups within a chemically coherent unit: "The only reliable means we have found for providing a regional stratigraphic breakdown of the Grande Ronde basalt is by field mapping of paleomagnetic polarities" (Swanson and others, 1979). Chemical composition and magnetic polarity not only separate out groups of flows of indistinguishable petrographic appearance (e.g., the Grande Ronde sequence), but they also provide a means of establishing the affinities of petrographically unlike flows (e.g., phyric and aphyric Frenchman Springs flows).

Because each basalt flow covered the existing topography, the thickness of any flow may vary from one locality to another. Similarly, the degree of crystallinity may vary with the local thickness of the cooling unit. Neither of these two variables is useful for characterizing basalt types. Thus the two main techniques used here for classifying isolated outcrops of coastal basalt are trace element geochemistry and magnetic polarity. 


\section{PROCEDURES}

This geochemical study of the coastal basalts was designed to serve a two-fold purpose: 1) to establish conclusively both the occurrence and identity of mapped basalts as individual Columbia River basalt chemical types, and, having established this, 2) to examine aerial distribution patterns of the basalt units. While previous workers sampling the whole extent of the coastal basalts have subjected samples to major oxide analys is (Snavely and others, 1973; Hi11, 1975; Tolson, 1976; Penoyer, 1977), no trace element analyses including this study area, other than Hill (1975) have been conducted.

If these basalts are the distal ends of plateau flows, one would expect to find only those units that have also been identified in western Oregon. Occurrences of units not previously identified in western Oregon would suggest either a western passage not yet discovered or a nonplateau origin.

Distribution patterns are of significance to any hypothesis regarding basalt origin. Linear arrangements of the outcrops of a single flow unit might represent either a dike marking a former fissure or the erosional inverted valley of an intracanyon flow. Perhaps the oldest flows and/or the most voluminous flows spread out over a larger area while the younger flows were confined to a central (downwarped) area, as was the case in the western Cascades (Beeson and others, 1979a). Or perhaps each succeeding flow was able to build further out on the platform created by the older flows. Distribution patterns could allow flow routes to be suggested to local or distant vent areas and could 
reveal the Miocene topography or tectonic regime. Although plateau basalts have not been traced through the Coast Range, distribution patterns could suggest where such pathways might have been or if all the basalt came down the lower Columbia River.

Within the arbitrarity limited study area, sampling was guided by accessibility of outcrop, shape of the plan view, and field determinations made during previous outings. Features to be sampled were generally selected from the maps of Schlicker and others (1972) and Beaulieu (1973); no attempt was made to remap basalt occurrences although contacts and structures were noted. Continuation of units from one outcrop to the next was not accurate and thorough sampling of all outcrops was not possible, so the features highlighted in this study are but a few pieces of the puzzle. Sample locations are indicated on Figure 9 and listed in Appendix B.

Care was taken to obtain unweathered geochemical samples and to sample the center of the unit rather than the margins. At the same time, magnetic polarity was measured at the outcrop using a portable fluxgate magnetometer. Samples were oriented with a Brunton compass and readings had to be repeatable. Magnetic polarity samples were taken from the lower margin of the flow because the slower-cooling flow interior's larger grains may be influenced later by the changing field and because the upper margin can be reheated by a succeeding flow. Hooper and others (1979) point out that the margins are more oxidized and therefore more likely to provide stable signals because the higher oxidation states retain their original magnetic signature better. In general, the original magnetism of a rock can be masked by such things 


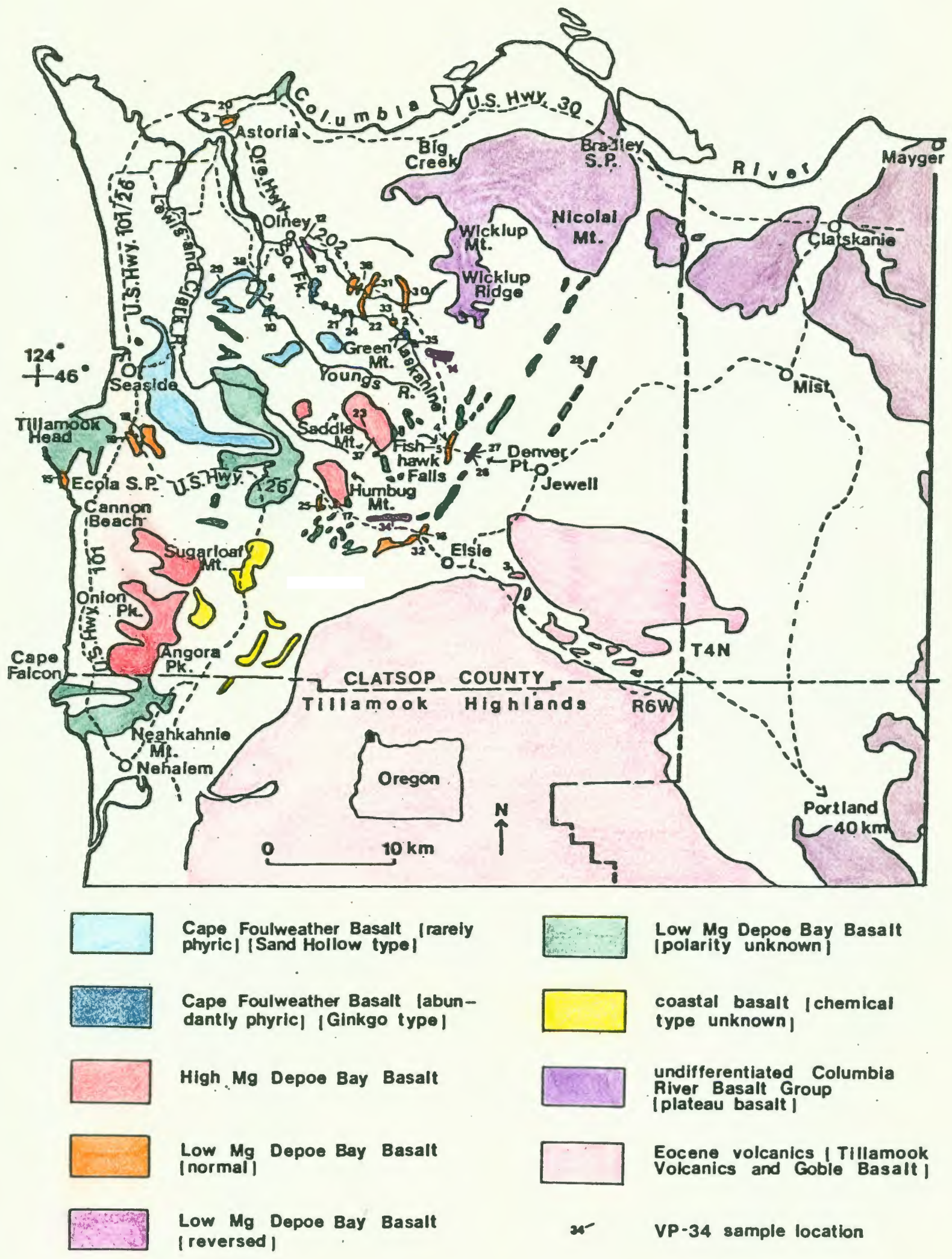

Figure 9. Location map of geochemistry samples and basalt types. (Base map from Wells and Peck, 1961; Schlicker and others, 1972; Beaulieu, 1973). 
as induced magnetism of the present field (in this case, a normal overprinting of a reversed flow), lightning strikes which can reverse the polarity in very localized areas, or alteration of magnetic minerals.

Measurement of the original magnetic orientation recorded in a rock can also be done in the laboratory with more sophisticated equipment. Although agreement between field and laboratory measurements is quite good (Choiniere and Swanson, 1979; Hooper and others, 1979;

Swanson and others, 1979), laboratory techniques are able to both "erase" all the overprinting in order to determine the true paleomagnetic orientation, including transitional ones, and to determine more precisely the particular inclination and declination of the paleomagnetic pole recorded. Eight of the coastal features included in this study were also sampled by R. Simpson of the U.S. Geological Survey in September 1979 for 1aboratory determination of the paleomagnetic direction.

\section{RESULTS AND DISCUSSION}

\section{Identification and Distribution}

A total of 38 samples were analyzed by Instrumental Neutron Activation Analysis (INAA) for the following 17 elements: La, Fe, Sc, Sm, Ba, $\mathrm{Hf}, \mathrm{K}, \mathrm{Co}, \mathrm{Na}, \mathrm{Ce}, \mathrm{Eu}, \mathrm{Yb}, \mathrm{Lu}, \mathrm{Th}, \mathrm{Ta}, \mathrm{Cs}, \mathrm{Cr}$. Experimental procedures are outlined in Appendix $A$; results are tabulated in Appendix $C$.

Identification was based primarily on the lithology, polarity, and the trace element geochemistry, specifically the concentrations of $\mathrm{Fe}$, $\mathrm{La}, \mathrm{Sc}, \mathrm{Sm}$, Th, Eu, and $\mathrm{Cr}$, as these elements are both the most distinguishing for identification purposes and the best resolved by the INAA method. Basalt units thus distinguished include the low $\mathrm{Mg}$ and high $\mathrm{Mg}$ 
Depoe Bay and Cape Foulweather. Plots of Fe vs. La (Figure 10) serve to illustrate the distinct groupings of basalt types, as does La/Sm vs. Eu (Figure 11). The Cape Foulweather flows have higher (usually $>9$ percent) Fe than either low or high Mg Depoe Bay basalts, which both have 7-9 percent Fe. Cape Foulweather basalt has higher Sm (> 7 ppm), Eu (> $2 \mathrm{ppm})$, and lower Th (<4.25 ppm); high Mg basalt has higher $\mathrm{Cr}$ (>25 ppm), lower Sm $(\leq 6 \mathrm{ppm})$, and lower La $(<22-24 \mathrm{ppm})$; low $\mathrm{Mg}$ basalt has lower Sc (30-35 ppm) (Hi11, 1975; Beeson and Moran, 1979). Hill (1975) plotted both his plateau and coastal basalt analyses to 1) distinguish the different chemical types, and 2) show the similarity of the plateau-coastal correlative units. Figures 12 and 13 show two of Hill's plots, Fe vs. Sc and Fe vs. Th, plus the analyses from this study. Basalts analyzed in this study fall within the limits previously determined for Miocene coastal basalt chemical types and thus also correlate with the plateau types.

Only one sample (VP-3) does not fall consistently within a single chemical type. VP-3 is mapped by Beaulieu (1973) on U.S. 26 just east of Elsie (Figure 9) as an Eocene intrusion within undifferentiated Eocene sedimentary rocks. Altered, grey, porphyritic (abundant plagioclase laths to $5 \mathrm{~mm}$, occasional pyroxene crystals to $2 \mathrm{~mm}$ ), it forms excellent columns $25-30 \mathrm{~cm}$ in diameter that plunge gently $\left(25^{\circ}\right)$ almost due north $\left(350^{\circ}-355^{\circ}\right)$. The pyroxene phenocrysts and columns physically distinguish this unit. Chemically, it has higher Sm (8.6 ppm) and lower Co $(29.42 \mathrm{ppm})$ than all the other samples; Eu is high (2.33 ppm) like Cape Foulweather basalt, but low Fe ( 8.7 percent) rules this identification out; Th is low (2.45 ppm) like high Mg Depoe Bay basalt. In most 


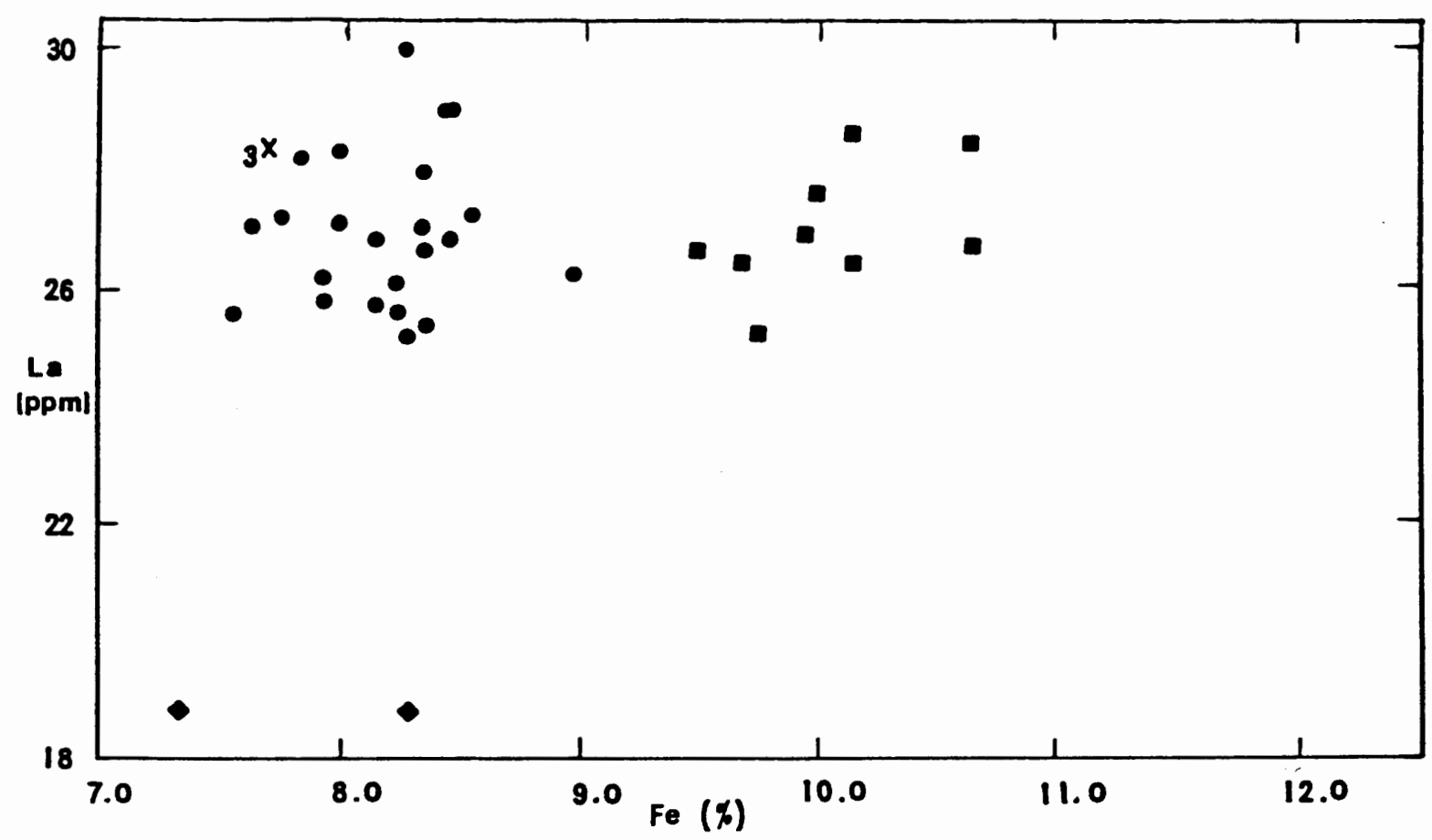

Figure 10. Plot of Fe vs. La concentrations. Circle $(\bullet)=$ low Mg Depoe Bay Basalt; diamond $(\bullet)=$ high Mg Depoe Bay Basalt; square $(\boldsymbol{E})$ = Cape Foulweather Basalt; $3^{X}=$ sample VP-3.

other elements, but not in lithology, this rock resembles low Mg Depoe Bay Basalt. Although the Tillamook volcanics cover a range of chemical variations, VP-3 would seem to have a higher $K$ and lower co than the values reported by Hill (1975). Due to its having characteristics in common with all the Miocene chemical types plus the Eocene volcanics and the sure identity of none, VP-3 cannot be classified conclusively on the basis of this analysis.

One sample (VP-9) experienced technical difficulties in the electronics of the detector/analyzer, and it has been discarded. The remaining 36 samples fall into three distinct groupings.

Low Mg Depoe Bay. The low Mg Depoe Bay basalts include a reversed and a normal magnetic unit. Although there are a total of two reversed and two normal magnetic subdivisions within the low $\mathrm{Mg}$ chemical type, 


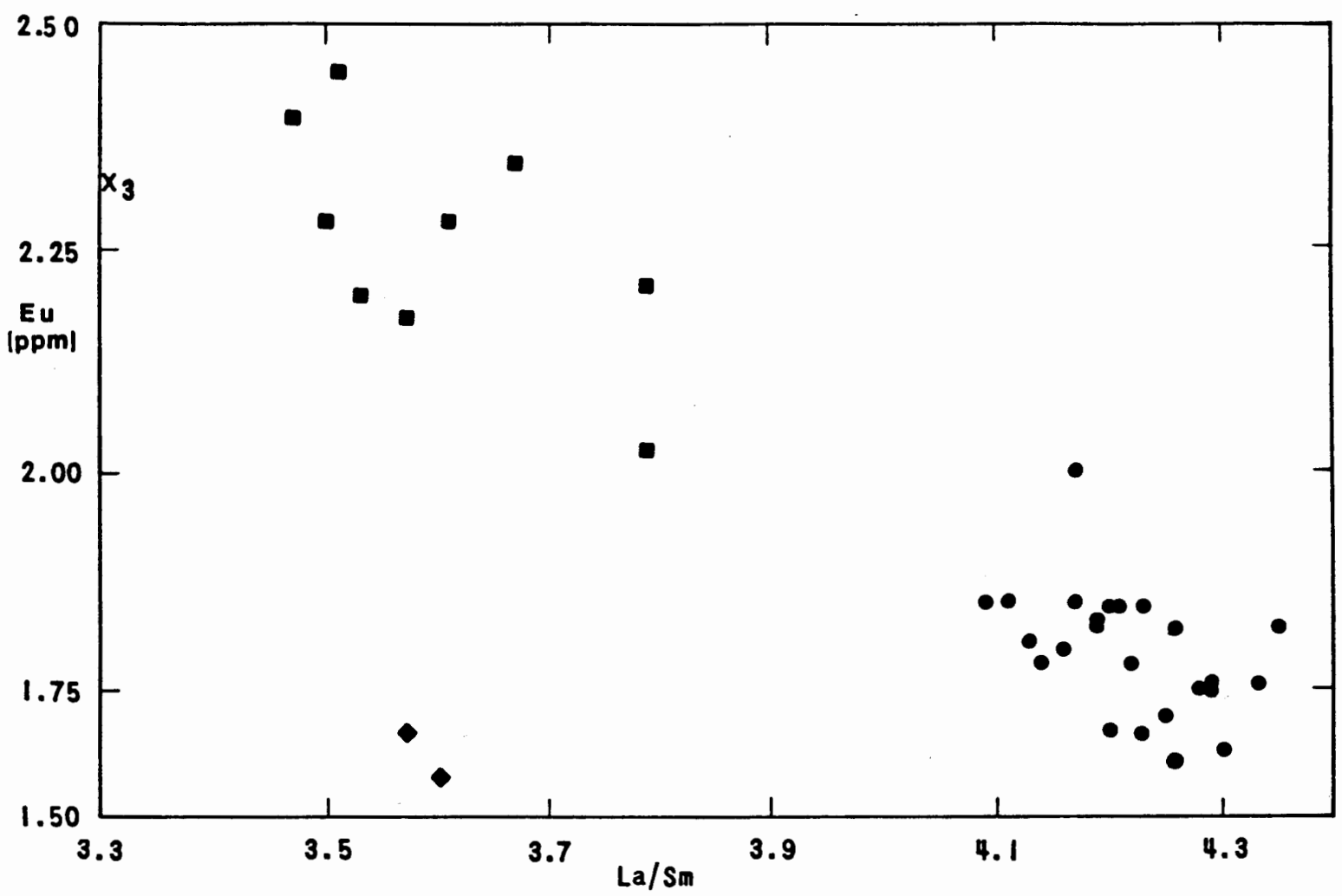

Figure 11. Plot of La/Sm vs. Eu concentrations. Symbols are as in Figure 10.

the oldest $\left(R_{1}\right)$ reversed is not found in western Oregon and the oldest $\left(N_{1}\right)$ normal is found as a single flow in Multnomah Creek and the Clackamas River drainage (Anderson, 1978; Beeson and Moran, 1979).

Therefore, all the reversed flows are assumed to be the same, younger $\left(R_{2}\right)$ reversed unit and 211 the normal flows are assumed to be the same, younger $\left(\mathrm{N}_{2}\right)$ normal unit.

The oldest Columbia River basalt type found in the coastal area is the reversed $\left(R_{2}\right)$ low Mg Depoe Bay. Locations of these seven samples $(V P-2,12,13,14,26,27,34)$ are plotted in Figure 9. Nelson's (1977) major element analysis of Sunset quarry rock (VP-12, 13) identifies the rock as low Mg type; Snavely and others (1973), using major elements, analyzed an outcrop along the assumed northeast continuation of Denver 


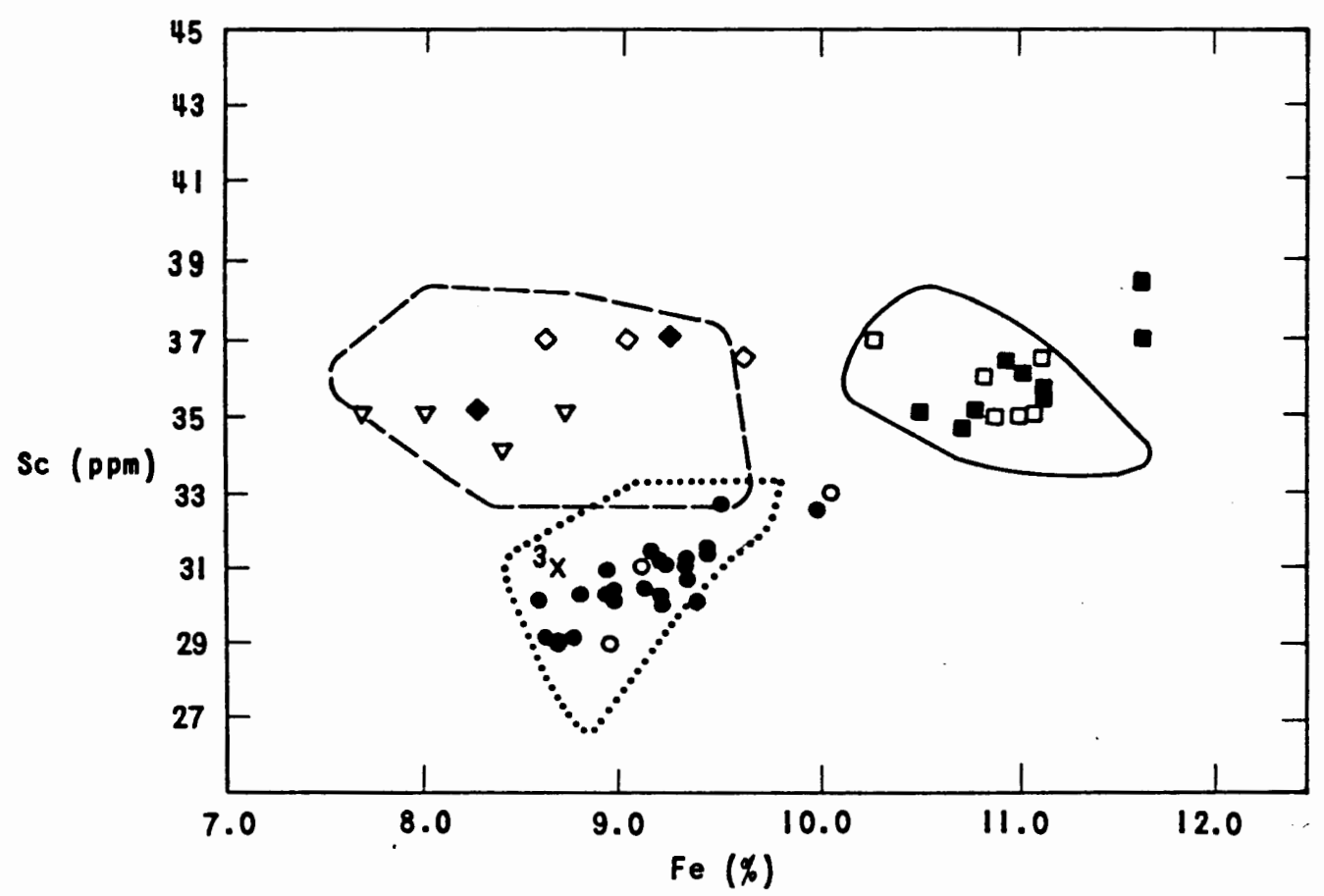

Figure 12. Plot of Fe vs. Sc concentrations. (Modified from Hi17, 1975). Solid symbols are for analyses of this study; open symbols are for analyses of Hill (1975). Circle (ro) $=$ low Mg Depoe Bay Basalt; diamond $(\diamond \bullet)$ = high Mg Depoe Bay Basalt; square (םm) = Cape Foulweather Basalt; triangle $(\nabla)=$ Pomona flow; ${ }^{3} x=$ sample VP-3. The regions for low $\mathrm{Mg}$ and high Mg Grande Ronde Basalt and Frenchman Springs basalt are designated by dotted, dashed, and solid lines, respectively.

Point (VP-26, 27) as low Mg. Neither of these two analyses included magnetic determinations.

Along Beneke Road which heads northeast immediately west of Jewe11, a series of mapped outcrops seems to define a linear pattern parallel to the longer series underlying Denver Point to the west. VP-28 is a sample from the northeasternmost mapped unit, which is extensively brecciated. The small core of solid rock is aphanitic to very fine-grained, dark grey basalt with plagioclase microphenocrysts. The reversed polarity suggests low Mg basalt, yet in La (21.24 ppm) and Sm (4.99 ppm), the sample matches high Mg chemistry. Although $\mathrm{Na}$ is unusual (< 2 percent), 


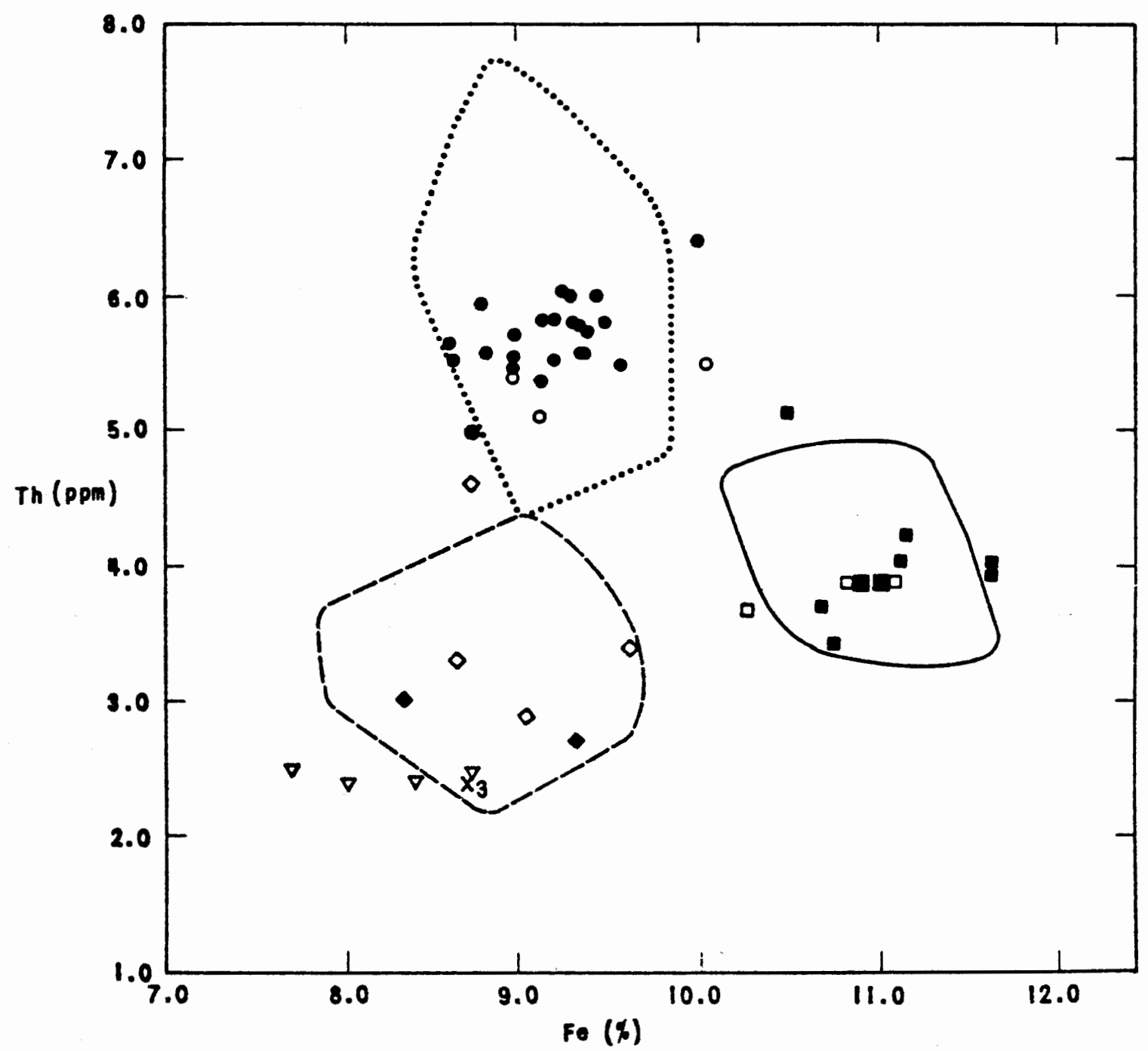

Figure 13. Plot of Fe vs. Th concentrations. (Modified from Hill, 1975). Symbols are as in Figure 12.

in other elements VP-28 most closely resembles low Mg basalt and has been classified as such. It lacks the very high $\mathrm{Cr}$ (100-106 ppm) and lithology for Pomona basalt; lacks the high (> 7 ppm) Sm, La (25-30 ppm) and Sc (35-40 ppm) to be Priest Rapids basalt; lacks the lithology and $\mathrm{Ba}(2000 \mathrm{ppm})$ and Eu (> $4 \mathrm{ppm})$ to be Prineville basalt.

Lithologically, the samples are all fine- to very fine-grained, grey, and equigranular with evidence of plagioclase, usually as laths 
less than one millimeter long; two samples (VP-34 and VP-27) each contain one 4-7 mm long clear plagioclase lath. As no significant differences were observed among the samples, the four locations they represent are assumed to be all the same flow, although three different reversed $\left(R_{2}\right)$ flows are identified in western Oregon (Beeson and Moran, 1979). Conceivably these samples could actually represent three different flows.

Polarities on both VP-12 and VP-14 were determined in the laboratory by R. Simpson (pers. comm., 1980) as reversed with overlapping (i.e., indistinguishable) confidence limits.

Reversed low Mg Depoe Bay flows are distinguishable from normal low Mg Depoe Bay basalt only by their magnetic polarity. As such magnetic determinations have not been routinely published for the coastal basalts in northwestern Oregon, hypotheses about the continuation of these reversed units beyond the study area is difficult. Within the study area, mapped outcrops of reversed low Mg basalt are generally rectangular (Figure 9). Linear patterns can be imagined extending southwest from the Nehalem basin (VP-28) through Denver Point (VP-26, 27) to VP-34; another line extends northwest along Highway 202, where intrusions are well exposed at Cooperage quarry (VP-14) and Sunset quarry (VP-12, 13). The reversed and normal low Mg basalts together separate the plateau and Eocene basalt flows on their east from the younger Miocene coastal basalt features on their west.

Sixteen samples determined to be low Mg normal $\left(\mathrm{N}_{2}\right)$ make up the second oldest coastal basalt unit (Figure 9). The rocks all tend to be grey, fine-grained, and equigranular, but fall into two tentative groups on the basis of a pervasive "mottling" or weathering characteristic: in 
half the samples $(V P-1,4,5,22,30,31,33,36)$ the interior rock becomes patchy while the exterior has a reddish to yellowish weathering coat. Plagioclase laths to $2 \mathrm{~mm}$ may be apparent (VP-1, 31). Samples from Barth Falls (VP-1) and Fishhawk Falls (VP-4, 5) as analyzed by R. Simpson (pers. comm., 1980) are normally polarized, indistinguishable from each other, and distinct from the other samples that he analyzed. The easily stained, mottled samples are spatially coherent, all found northwest of Jewell along Highway 202 at Fishhawk Falls (VP-4, 5), the "ring dike" on the South Fork of the Klaskanine River (VP-22, 30, 31, 33), at Barth Falls (VP-1), and just southeast of Barth Falls (VP-36).

The remaining eight samples appear more homogeneous (VP-15, 16, $17,18,19,20,25,32)$ and are found over a wide area: from the Coxcomb Hill sill in Astoria (VP-20) south to the dike on Highway 26 just west of Elsie (VP-16, 32); the dikes south (VP-17) and southwest (VP-25) of Humbug Mountain are low Mg basalt, similar to basalts exposed in quarries on Highway 26 just east of Tillamook Head (VP-18, 19) and at Ecola State Park (VP-15). Penoyer (1977) analyzed the large, non-porphyritic dike southwest of Humbug Mountain (VP-17), which is low Mg on the basis of major elements.

The peculiar weathering habit which superficially separates the normally magnetized low Mg Depoe Bay basalt unit into two groups may not be a significant or valid distinction; no other differences between the samples were observed.

Tolson (1976) mapped a large area of low Mg Depoe Bay flow, breccia, local peperites, and pillow basalts between the Lewis and Clark and Youngs Rivers and speculated that a large sill underlies much of 
that area. Penoyer (1977) carried that unit east toward Humbug Mountain and south in the direction of Neahkahnie Mountain, a thick low Mg basalt accumulation (Snavely and others, 1973). While the dikes south and east of Saddle and Humbug Mountains are low Mg Depoe Bay basalt and Penoyer (1977) analyzed a flow at the southeast base of Humbug Mountain as low $\mathrm{Mg}$, the mass of Humbug Mountain breccia is very similar to the high $\mathrm{Mg}$ Depoe Bay basalt breccia of Saddle Mountain.

High Mg Depoe Bay. Only two samples were analyzed as high Mg Depoe Bay basalt chemical type: one (VP-37) is of fragments in the Saddle Mountain breccia; the other (VP-23) is from one of the northeasttrending dikes encountered along the Saddle Mountain trail to the top (Figure 9). Both are dark grey with abundant plagioclase microphenocrysts; the dike is coarser (very fine-grained) than the breccia clasts (aphanitic). Snavely and others (1973) analyzed a pillow from Saddle Mountain as Depoe Bay basalt, and its 4.7 percent Mg0 further identifies it as high Mg; the sample correlates with VP-37. Penoyer (1977) identified a "nonporphyritic dike on Saddle Mountain", which is VP-23, as high Mg chemical type using major elements. Penoyer analyzed one additional non-porphyritic high Mg sill about $2.5 \mathrm{~km}$ west of Humbug Mountain, as did Tolson (1976) $14 \mathrm{~km}$ to the north. These are the only known outcrops of high Mg basalt in the study area; Humbug Mountain, so similar to Saddle Mountain and only $3.5 \mathrm{~km}$ away, may be composed of high Mg breccia also, although Penoyer's (1977) analys is of a flow at its base is low Mg basalt. Isolated outcrops of low Mg and high Mg basalt cannot be readily distinguished in the field, so without laboratory analysis, the separate distribution of the two types is not certain. 
High Mg Depoe Bay basalt is analyzed near Nicolai Mountain and at Cannon Beach (Snavely and others, 1973); Baldwin (1952) notes the simiTar breccias at Saddle Mountain, Humbug Mountain, Onion Peak and nearby peaks, and Wickiup Mountain; to this 1 ist Niem and Van Atta (1973) add Sugarloaf Mountain and Angora Peak, and Dodds (1970) adds Big Creek canyon. Layfield (1936) suggested that Saddle and Humbug Mountains were once connected and then eroded. Known and presumed high Mg basalt forms a broad band extending southwest from the Big Creek/Wickiup Mountain area through Saddle Mountain and Humbug Mountain and out of the study area to peaks such as Onion, Sugarloaf, and Angora.

Cape Foulweather. Cape Foulweather basalt, the youngest and perhaps most varied chemical type found in the study area, was assigned to 10 basalt samples on the bases of lithology and trace element geochemistry: $V P-6,7,8,10,11,21,24,29,35,38$ (Figure 9). The basalt at Youngs River Falls (VP-6, 7, 29, 38) is aphanitic to medium-grained with rare plagioclase phenocrysts up to $5 \mathrm{~mm}$ long. Geochemically it is distinguished from the other Cape Foulweather samples by high $\mathrm{Cr}$ (>45 ppm) (cf. Hil1, 1975). Snavely and others (1973) identified basalt from the Youngs River Falls quarry (VP-6) as Cape Foulweather on the basis of major elements; the same basalt was analyzed by R. Simpson (pers. comm., 1980) as normally polarized. The high $\mathrm{Cr}$, normal polarity, and rare plagioclase phenocrysts suggest that this Youngs River Falls basalt is correlative with the Sand Hollow flow of the Frenchman Springs member, noted for its high Cr (Atlantic Richfield Hanford Co., 1976; McDouga 11, 1976) and sparse plagioclase phenocrysts (Atlantic Richfield Hanford Co., 1976). Penoyer (1977) reported Cape Foulweather intrusives west of the 
Lewis and Clark River (Figure 9) with sparse plagioclase phenocrysts and 2-5 percent olivine in the groundmass, which also distinguishes Sand Hollow (Atlantic Richfield Hanford Co., 1976). However, his extrusive Cape Foulweather breccia and pillow lavas, also with rare phenocrysts, have 0-4 percent olivine, which does not clearly match the Sand Hollow olivine content.

The smaller basalt feature (VP-10) $1.4 \mathrm{~km}$ southeast of the Youngs River Falls dike resembles closely the samples on the South Fork of the Klaskanine River (VP-21, 24) and along Highway 202 (VP-35). They are all fine- to medium-grained with abundant plagioclase phenocrysts $5-10$ mm long; the outcrop near Youngs River Falls has occasional glomerocrysts more than $2 \mathrm{~cm}$ long. The basalt southeast of Youngs River Falls (VP-10) is normally polarized, but its confidence oval does not overlap the Youngs River Falls oval (R. Simpson, pers. comm., 1980). The low concentration of $\mathrm{Cr}$ in these abundantly phyric samples (VP-10, 21, 24, 35) suggests further that they are equivalent to a Frenchman Springs Ginkgo flow, noted for abundant plagioclase phenocrysts and glomerocrysts (Atlantic Richfield Hanford Co., 1976).

Seal Rocks and the Otter Crest "volcanic neck" (VP-8, 11) south of the study area are aphanitic to very fine-grained with abundant but generally smaller plagioclase phenocrysts (maximum observed length $7 \mathrm{~mm}$; usual length less than $5 \mathrm{~mm}$ ). Kienle (1971) identified a lower Ginkgo flow of reversed, transitional polarity at Oregon City, in the Dalles area, and at the Mosier syncline in the Columbia River Gorge. This unique paleomagnetic marker horizon, which he correlates with the basal Ginkgo flow at Vantage, Washington, is not found along the lower Columbia 
River valley (Kienle, 1971) or in the Clackamas River drainage (Anderson, 1978). Kienle (1971; pers. comm., 1980) reported a technically reversed Cape Foulweather Basalt at Seal Rocks (VP-11); Choiniere and Swanson (1979) determined that samples from the volcanic neck (VP-8) and Rocky Point are reversed and correlative with two distinct flows in southcentral Washington. Interlaboratory differences and varying corrections for dip notwithstanding, samples VP-8 and VP-11 and the flows of Oregon City and the Mosier syncline may be the same, highly unusual, reversed Frenchman Springs flow.

These tentative Cape Foulweather correlations to the Frenchman Springs stratigraphy would make the southern, reversed, lowest Ginkgo flows the oldest; the next oldest are the Ginkgo outcrops southeast of Youngs River Falls; and the Youngs River Falls Sand Hollow flow would then be the youngest Cape Foulweather unit. A transitional or excursional reversed flow exposed to a normal field could be overprinted as normal, concealing its reversed character from the fluxgate maznetometer. However, samples for each Cape Foulweather type were Taboratory-analyzed and thus can be concluded to be truly distinct, especially as their lithology, geochemistry, and spatial locations indicate the same groups.

Tolson (1976) and Penoyer (1977) both reported a non-porphyritic basalt with Cape Foulweather chemistry west of the Lewis and Clark River (Figure 9) which they each mapped as Depoe Bay on the basis of 1ithology while noting (Tolson, 1976) that perhaps the presence or absence of phenocrysts was not a sufficient identification criterion. Such an aphyric Cape Foulweather flow was not identified in this study area. Penoyer (1977) mapped this aphyric unit, however, at the base of a $100 \mathrm{~m}$ 
thick non-porphyritic sill, the top of which is low Mg Depoe Bay basalt.

The Cape Foulweather Basalt is limited primarily to the western portion of the study area. The abundantly porphyritic basalt forms a west-northwest band along the South Fork of the Klaskanine River while the sparsely porphyritic flows and intrusions form a broad arcuate band generally extending along the Youngs River and west of the Lewis and Clark River.

\section{Pattern}

Patterns can be both expected by and explained by either hypothesis regarding coastal basalt origin. In examining the coastal basalt pattern as a whole (Figure 4), Snavely and others (1973) suggested:

The regional distribution of dikes and sills suggests that the basalt magma that fed the coastal Miocene basalts rose along a major north-trending deep crustal fracture zone that extended from Seal Rocks northward to Hoquiam and that this zone was offset by a major northeast-trending fracture zone that also controlled the emplacement of Miocene intrusive rocks.

The "northeast-trending fracture zone" includes the study area.

Faults, folds, and lineaments for northwestern Oregon have decidedly northeast or northwest trends; these structurally weaker zones along which rocks have moved could have provided ascension routes for underlying magma. Local vents controlled by tectonic forces would probably define linear zones. In the plateau, vents for single flows are confined to narrow linear systems along the trend of the dike swarm rather than scattered throughout the area covered by a flow (Swanson and others, 1975; Swanson and Wright, 1976).

In the plateau-origin hypothesis, basalt flows in western Oregon would be controlled by surficial structures such as stream valleys and 
resistant high masses. But topographic structures could also be created and controlled by the same stress regime called upon to allow linear vent systems to operate. Once a flow filled a stream valley, the stream would have to relocate, usually adjacent to the old stream valley. This progression would result in inverted topography and subparallel, possibly linear systems.

Non-linear dike patterns could be produced by lava following sinuous drainage systems (e.g., deltaic distributary channels, meandering streams) or being diverted into intersecting routes or around topographic highs or by curvature related to dip or local stress. On the plateau, Taubeneck (1970) found that trends of dikes are most consistent in competent host rock without planar structures. Such dikes tend to be vertical and straight. Bedding, schistosity, contacts, and faults commonly cause deviations in the trend. None of the coastal intrusions are found in competent host rock, and irregularity in dike form and trend is the rule. As Beeson and others (1979b) point out:

Non consistent orientations of dikes is evident, indicating the apparent lack of a regional stress pattern, such as was present in the Columbia Plateau. In most cases, in fact, the dikes can be described as irregular rather than tabular masses.

The dikes themselves are irregular rather than straight and vertical; they are not oriented in a consistent or parallel arrangement with in a zone; they do not as flow groups define parallel linear zones.

A rough pattern can be described from the myriad of isolated coastal basalt outcrops in the study area (Figure 9). The reversed and normal low Mg basalts occurring from the Wickiup Ridge area northwest to Astoria and from Nicolai Mountain southwest to Elsie and Neahkahnie 
Mountain separate the Eocene and plateau basalts from the younger Miocene coastal basalts to the west. Exposures of the normal 1 ow $\mathrm{Mg}$ flows also occur from Elsie west to Tillamook Head and from Youngs River Falls south to Sugarloaf Mountain. The high Mg basalts, occurring in a northeast-southwest band from Wickiup Ridge/Nicolai Mountain to Angora Peak, are flanked by predominantly low Mg flows. Outcrops along the northwest-trending South Fork of the Klaskanine and parallel Youngs Rivers are Cape Foulweather Basalt, which also dominates an arcuate region between the Lewis and Clark River and the ocean.

The chemical analyses performed in this study must modify previous models for coastal basalt generation. The Depoe Bay Basalt linear system which seemed to extend from Nicolai Mountain southwest past Elsie is now known to be composed of at least two basalt types: on Highway 26 near Elsie the basalt is normal low Mg; on Highway 202 at Denver Point it is reversed. The Denver Point reversed dike is probably related to the reversed unit just east of. Humbug Mountain and perhaps to the reversed unit northeast of Jewe11 on Beneke Road. The samples from Denver Point and east of Humbug Mountain are the two with the single large plagioclase laths (page 47). Northwest-trending reversed outcrops form a second trail, perhaps diverging from the first somewhere near Nicolai Mountain, where a reversed flow could have entered the coastal region.

Linear zones or sinuous patterns can be devised for the pervasive low Mg normal units. Perhaps the basalt at Fishhawk Falls swung around through the intrusions under Saddle Mountain and back north to the Klaskanine River oxbow and Barth Falls. Maybe the Klaskanine River 
outcrop is a ring dike and elsewhere the normal low $\mathrm{Mg}$ intrusions are remnants of vent systems subparallel to the older reversed ones. Both low Mg basalt types are almost exclusively intrusive in the east and north, joined by extrusive units in the region west of the high $\mathrm{Mg}$ basalt. Even this observation can be explained either as intrusions concentrated in narrow vent systems while flows occur (with intrusions) over an adjacent area (cf. the Columbia Plateau), or as flows confined to stream channels and then emptying into and invading marshy nearshore areas at the river outlets.

The high Mg Depoe Bay basalt outcrops form a band with a bend in it subparallel to the bend in the low Mg system as it heads west toward Humbug Mountain. This bend seems to reflect the Eocene Tillamook Highlands contact line. The high Mg flow(s) might have come down the lower Columbia downwarp to Nicolai Mountain and Wickiup Ridge and then southwest through Saddle and Humbug Mountains, turning along a path west toward Tillamook Head but eventually heading southwest through Sugarloaf Mounta in to Angora Peak. Baldwin (1952) traced the Wickiup Mountain breccia east to plateau units at Bradley State Park. The high Mg path has low Mg intrusions on the landward side and both extrusive and intrusive units on the seaward side. The extrusive mass would be easier to erode and a stream settling in on the contact could provide a path for the high Mg basalt and water for extensive brecciation. Or maybe the high Mg lava was channeled by downwarping due to low Mg basalt accumulation and loading in the central area. Ponded water or wet unconsolidated mud could have resulted in the brecciation of the high $\mathrm{Mg}$ basalt (Layfield, 1936). 
Assuming Humbug Mountain breccia to be high Mg Depoe Bay, as Saddle Mountain breccia is, and the intrusions south and east of both mountains to all be low Mg Depoe Bay, as the ones analyzed proved to be, the younger high Mg basalt conveniently overlies the older low Mg basalt. Baldwin (1952) reported a north-northwest dip of $10^{\circ}$ for the Saddle Mountain breccias (rudely stratified), which neatly accounts for the exposures of older material, including Penoyer's (1977) low Mg flow, on the south and east sides of both Saddle Mountain and, by analogy, Humbug Mountain. The high Mg dikes within Saddle Mountain could be autointrusive from a still molten mass within the body of the mountain or a second flow filling the joints that formed parallel and perpendicular to the Saddle Mountain northwest-trending ridge.

Alternatively, the high $\mathrm{Mg}$ basalts erupted along a northeast fissure zone into water or water-saturated sediments. Feeder dikes would have to be hidden beneath the mountains and eroded away in between the mountains. Neither Layfield (1936) nor Baldwin (1952) considered the small dikes within Saddle Mounta in to be feeders; there are no known dikes on Humbug Mountain. The dikes preserved between the mountains are not feeders, as Baldwin (1952) speculated, because they are not of high Mg chemistry.

The oldest of the Cape Foulweather Ginkgo flows (reversed) apparently came through the Mosier syncline and along a route to Oregon City, from whence it flowed through to the coast to form the Seal Rocks sill. Such a localized flow, not found in major basalt piles (e.g., Multnomah Creek, Clackamas River), indicates a probable intracanyon flow, which also gives the lava a pathway through the emerging coast 
Range. A local origin for this magnetically distinct flow requires almost simultaneous eruption with its plateau equivalent in a very localized area.

The younger Ginkgo flow, normally polarized, forms a series of dikes and sills along the South Fork of the Klaskanine River, either a vent system or a localized flow, mostly confined to the Astoria Formation (Dodds, 1963). Access to this area for a flow could have been from Wickiup Ridge, the top $183 \mathrm{~m}$ of which are porphyritic flows (Dodds, 1963), and from there down the Klaskanine River, turning southwest near Youngs River Falls and into a mass of sediments overlying the Depoe Bay Basalts; Penoyer (1977) reported Cape Foulweather dikes, sills, and flows locally abundantly porphyritic east of Tillamook Head. Offshoots could have flowed to the immediate northeast of Saddle Mountain, where Penoyer (1977) recorded a one meter thick dike and rare float of Cape Foulweather Basalt. (This porphyritic dike has Depoe Bay chemisty; rare Grande Ronde flows are porphyritic and are found in western Oregon (M.H. Beeson, pers. comm., 1980).) Dodds (1963) reported porphyritic basalt dikes cutting Green Mountain (between the Youngs and Klaskanine Rivers, Figure 9). Green Mountain itself, however, is described as having only "occasional large feldspar phenocrysts" (Dodds, 1963), suggesting it is the younger Sand Hollow flow. Perhaps these porphyritic dikes are autointrusive Sand Hollow basalt type, or perhaps the abundantly porphyritic flow is not a Ginkgo flow but instead a younger flow.

The Sand Hollow flow is found at Youngs River Falls and at Green Mountain and Eels Ridge (aka Green Mountain Sister or Sister Green) as remnants of thick medium-grained sills; Tolson (1976) suggested that 
Green Mountain Sister, composed of intrusive and extrusive Cape Foulweather Basalt, may be a southern extension of the Youngs River Falls system. The "ring dike" at Youngs River Falls displaces gently dipping marine sedimentary rocks to near vertical orientation at the contact; the arcuate shape and disruptive nature of the basalt feature could be compatible with a local origin. Alternatively, this sinuous dike resembles an oxbow in plan (Beeson and others, 1979b), suggesting control by a stream parallel to but south of the abundantly porphyritic intrusions. Sparsely porphyritic sills follow Youngs River northwest to Youngs River Falls. Here the basalt pattern starts a hairpin turn which coincides with the oxbow and oxbow cutoff imaginable from Tolson's (1976) map. Rarely phyric Cape Foulweather Basalt forms a broad arcuate ridge of extrusive rock curving around seaward of the Lewis and Clark River, paralleling the Depoe Bay basalt/sediment contact, and thinning to the south to but tens of meters thick (Tolson, 1976; Penoyer, 1977). Perhaps here the ancestral Lewis and Clark River had nearly eroded the Depoe Bay Basalt in its path when the Cape Foulweather Basalt displaced it to the north. Other scenarios are certainly possible. 


\section{GEOPHYSICS}

\section{INTRODUCTION}

To what depth the coastal basalt dikes extend is a critical test of the alternative hypotheses regarding their origin. Dikes marking former vents would likely be connected at depth with a magma source or conduit, i.e., these dikes would be "rooted" at depth. Invasive flows, on the other hand, would be "rootless." The coastal basalts occur in marine sediments, and these two rock types can be distinguished on the basis of their physical properties such as density, seismic velocity, and magnetic susceptibility. This makes subsurface investigation of the coastal basalts particularly amenable to geophysical methods. The principal geophysical technique employed in this study was gravity.

In 1964, Bromery and Snavely published gravity and magnetic traverses and constructed a regional geophysical picture of northwestern Oregon. In conjunction with this survey, Snavely and Wagner (1964) determined formation densities for the major rock types in the coast Range area. Berg and Thiruvathukal (1967) made a gravity survey of the state of Oregon and produced the state Complete Bouguer Gravity Anomaly and Free Air Gravity Anomaly maps, and Thiruvathukal and others (1970) discussed the regional gravity of Oregon in terms of crustal depths and patterns. These studies are continued offshore by Dehlinger and others (1967) and north into Washington state and Washington offshore by Bonini and others (1974). 
Three areas were chosen for detailed geophysical investigation (Figure 14) based on accessibility, basalt outcrop pattern, and basalt type: 1) Youngs River Falls, a U-shaped feature of Cape Fou Tweather chemistry, accessible via a network of Crown Zellerbach logging roads; 2) the South Fork of the Klaskanine River, a "ring dike-like" feature of low Mg Depoe Bay chemistry, accessible via Crown Zellerbach and Oregon State Forestry Department roads; 3) Fishhawk Falls and Denver Point near Jewel1, two parallel Tinear dikes, both of low Mg Depoe Bay chemistry but one normally polarized and one reversed, intersected by State Highway 202. In all cases, the access road runs approximately perpendicular to the strike of the outcrop under study.

\section{PROCEDURES}

Seven gravity lines, four in this study, have been conducted over these coastal basalt dikes. At Youngs River Falls, two roughly perpendicular lines cross and parallel the axis of the $U$ : 34 stations (A-B line) crossing the southeast limb were measured by A.G. Johnson, M. Moran, R. Perttu, and M.H. Beeson (pers. comm., 1978); 55 stations ( $P$ line) continue this 1 ine across the northwest $1 \mathrm{imb} ; 26$ stations (S-N line) and 13 stations (" 80 " 7 ine), together constituting a traverse along the $U$ axis, were measured by the 1979 and 1980, respectively, Portland State University Field Geophysics classes (pers. comm., 1979, 1980).

The ring dike-like basalt outcrop on the South Fork of the Klaskanine River was traversed by two gravity lines, one over each of the crescent-shaped segments. Fifty-five stations ( $T$ line) across the 


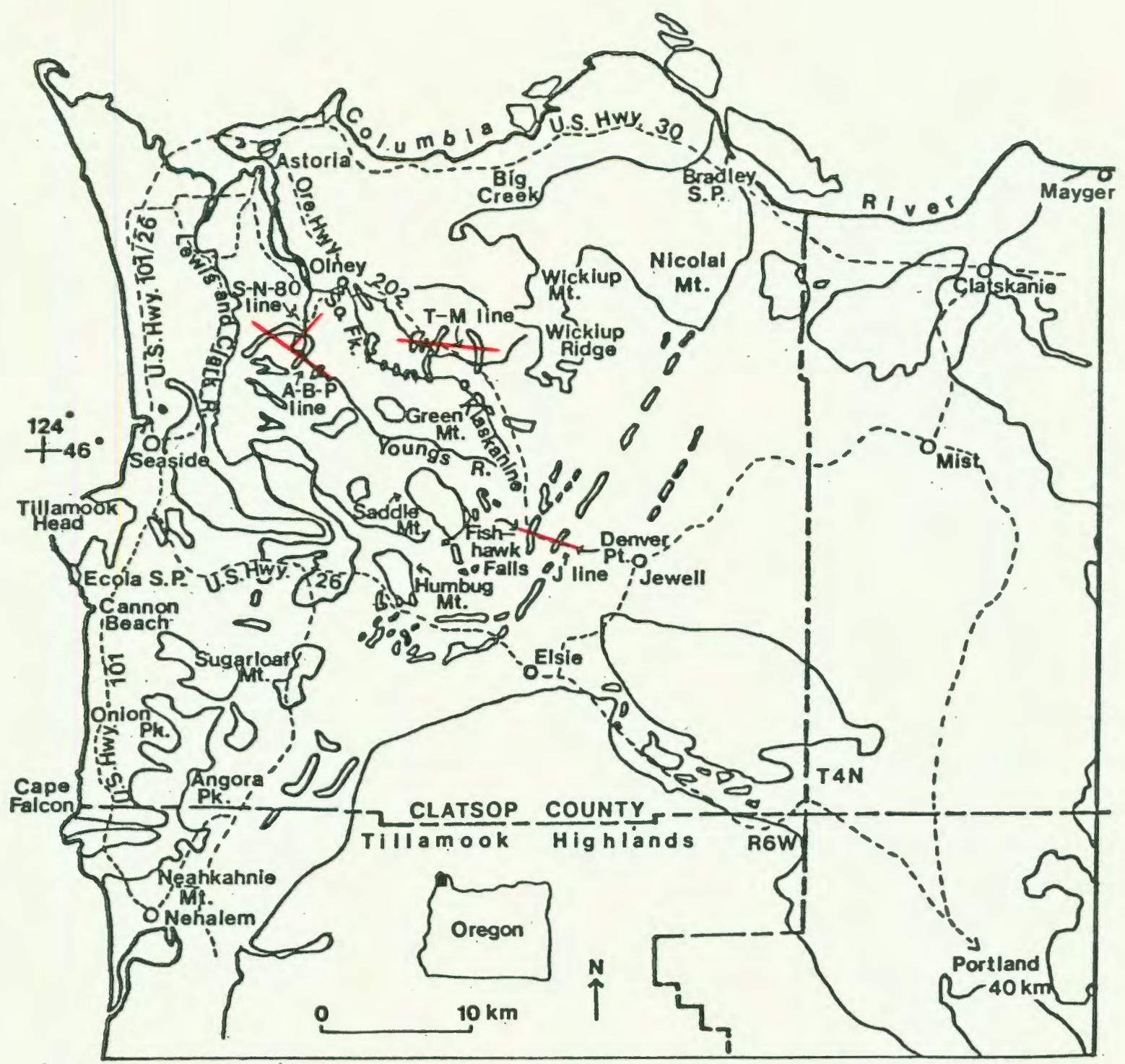

Figure 14. Location map of gravity traverses (marked in red) over coastal basalt features. (Base map from Wells and Peck, 1961; Schlicker and others, 1972; Beaulieu, 1973).

northeast dike are continued southwest of Highway 202 by 39 stations (M Tine) across the southwest dike.

The two parallel linear dikes approximately six kilometers northwest of Jewell are intersected by Highway 202, along which 76 stations (J line) were occupied.

Spacing between stations was controlled by distance to the outcrop. 
In general, stations were $20 \mathrm{~m}$ apart directly over the basalt, increasing to about $50 \mathrm{~m}$ separation for $200 \mathrm{~m}$ on either side of the basalt; stations extending the lines to establish the background values were about $100 \mathrm{~m}$ apart.

Measurements were read with a Worden gravimeter kindly loaned by the School of Oceanography, Oregon State University. Stations on lines $P, T, M$, and $J$, established in this study, were first paced, read with the gravimeter, and marked with five-inch nails and flagging. Within a week, the stations were reoccupied during the transit survey to establish elevation and location. The $\mathrm{J}$ line across Fishhawk Falls and Denver Point was surveyed into a local U.S. Coast and Geodetic Survey benchmark ( $Z$ 195) on Highway 202; for the other six lines, one station plotting on a contour line was assigned that contour's value and all other stations were measured relative to it. (All four lines at Youngs River Falls are tied to the same point.) This rails-and-flagging system worked admirably with one mysterious exception: upon returning to the M line, all traces of the station markers were gone. These station locations were approximately recovered by the previously recorded pacing between stations, and the elevations were estimated from a $1 ": 1000^{\prime}$ map contoured at $20^{\prime}$ intervals provided by the Crown Zellerbach corporation. Absolute gravity, established as 980641.35 mgals at Portland State University by Beeson and others (1976b), was read at the beginning and end of each field day. Local base stations in the field were reoccupied approximately every two hours and were tied to the Portland State University station. At least two acceptable readings were taken at every gravity station; readings had to be repeatable to $.01 \mathrm{mgal}$ (.1 dial 
division). Instrument temperature was read at every station, and all observed readings were multiplied by a temperature-correction factor published by Texas Instruments, Inc. (1963). To compensate for instrument drift and tidal forces, a drift curve for each field day was manually coristructed, and all readings were corrected to it.

Terrain corrections were performed by hand using the Hammer method as outlined by Dobrin (1976). Zones D-I were calculated at station spacings not greater than $250 \mathrm{~m}$; zone $\mathrm{J}$ was calculated approximately every $500 \mathrm{~m}$; zones $\mathrm{K}-\mathrm{L}$ were calculated at stations spaced approximately every $750 \mathrm{~m}$; zone $M$ was read at the end and midpoint stations for each line. Values for intermediate stations were linearly interpolated. Base topographic maps used were U.S. Geological Survey $71 / 2^{\prime}$ quadrangles (available only for the Youngs River Falls area), 15' quadrangles, and 1:250,000 sheets.

Al1 transit survey data were reduced to establish an elevation, latitude, and longitude for each station. A best fit straight line was approximated to each traverse perpendicular to the strike of the basalt feature, and all stations were projected onto it.

Computer program GRAVPLOT (Jones, 1977), when suppl ied with station elevation, terrain correction, latitude, and observed absolute gravity, calculated the theoretical gravity, Free Air Correction, Free Air Anomaly, Bouguer Correction, Simple Bouguer Anomaly, and Complete Bouguer Anomaly; these data are tabulated in Appendix D. The 1930 International Formula was used to compute theoretical gravity. Both the Bouguer and terrain corrections were based on the standard reduction density of $2.67 \mathrm{~g} / \mathrm{cc}$. The terrain correction, however, was later 
adjusted according to the variation of surface rock densities from this standard.

Errors in gravity are estimated as follows:

$\begin{array}{ll}\text { elevation } & .03 \mathrm{mgal} \\ \text { latitude } & .01 \mathrm{mgal} \\ \text { instrument reading } & .01 \mathrm{mgal} \\ \text { terrain correction } & .05 \mathrm{mgal} \\ \text { drift } & .03 \mathrm{mgal}\end{array}$

Since the error sources are random, the total error can be estimated by $\sqrt{\Sigma e^{2}}$, where $e$ is the error due to each source (A.G. Johnson, pers. comm., 1979). For this study, then, an error of .07 mgal may be associated with each gravity value.

Modelling was done on the Portland State University Honeywe11 computer using BOUGUERFIT and FREEAIRFIT, previously adapted from Oregon State University programs and described in Jones (1977). These programs consider only a two dimensional cross-section, the third dimension being assumed infinite and parallel to strike. Errors due to the two-dimensional assumption were not considered here. The subsurface is approximated by polygonal shapes of specified density, the gravity contribution of which are tabulated at locations along the surface. Both programs are equipped to subtract out three different regional gradients from the calculated gravity anomaly.

Regional gravity surveys conducted for Oregon onshore (Berg and Thiruvathuka1, 1967a,b) and offshore (Dehinger and others, 1967) and for Washington (Bonini and others, 1974) (Figures 15 and 16) were used to estimate the regional gradient along each traverse. A listing of individual station locations and values measured for northwestern Oregon was provided by the School of Oceanography, Oregon State University. 


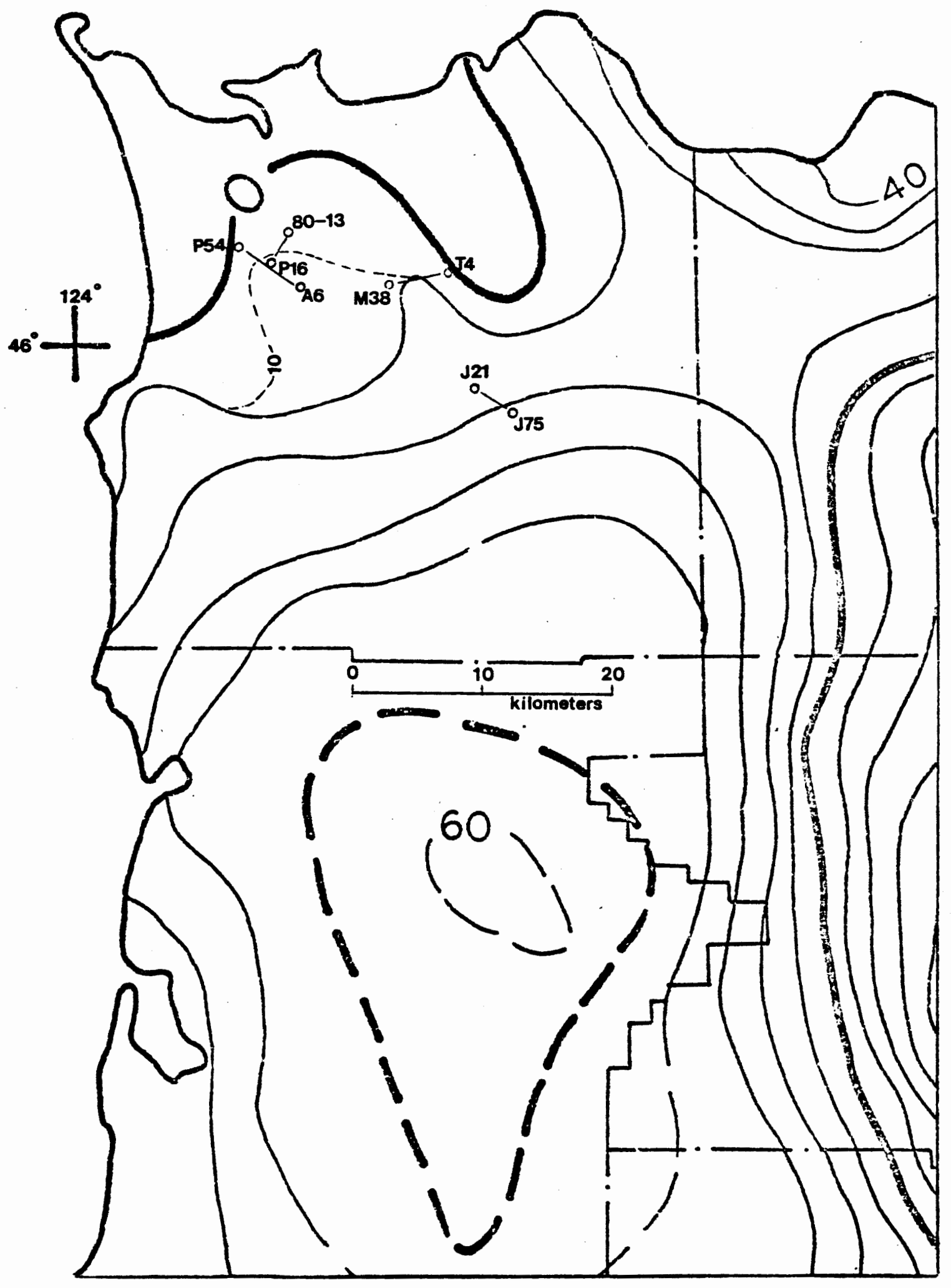

Figure 15. Regional Complete Bouguer Gravity Anomaly map of northwest Oregon. (From Berg and Thiruvathuka1, 1967b). Lightly dashed line is revised (this study) +10 mgals contour. 


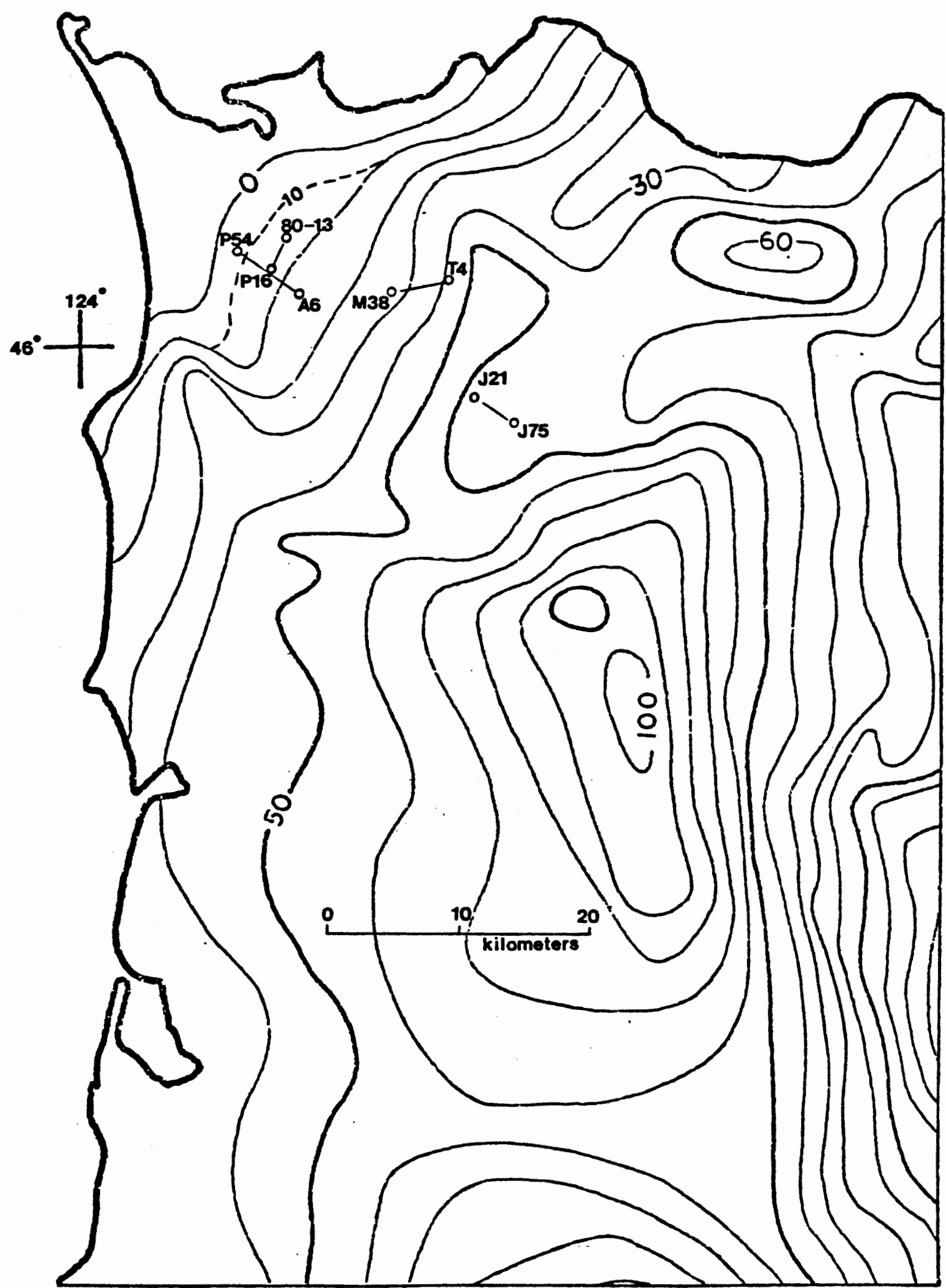

Figure 16. Regional Free Air Gravity Anomaly map of northwestern Oregon. (From Berg and Thiruvathukal, 1967a). Lightly dashed line is revised (this study) +10 mgals contour. 
In applying filters to the regional gravity data of Oregon, Thiruvathukal and others (1970) generated regional contour maps that emphasized anomalies originating at various depths. For both the Complete Bouguer Anomaly (CBA) and the Free Air Anomaly (FAA), the regional gravity due to mass distributions at or deeper than $63 \mathrm{~km}$ shows a steadily decreasing gradient from the coast to the Willamette Valley. But masses at depths of approximately $15 \mathrm{~km}$ (1ower crust) on both the CBA and FAA show a steep increase eastward over the study area, presumably due to the Eocene Tillamook Highlands (Bromery and Snavely, 1964). These relatively shallow regional trends influence the local gravity traverses, and correction factors often are required to separate out and eliminate their effects. In this study, the regional gravity correction was a gradient applied as a function of distance and effectively was subtracted from the observed reading, although practically, the factor was simply read into the modelling programs and the correction added to all calculated points.

The gravity models were extended approximately $70-100 \mathrm{~km}$ on both sides of the study area to eliminate edge effects due to otherwise abrupt ends of model lines, and to allow for the gravity contributions of nearby features not specifically traversed. Effects of the lower crust and mantle are assumed to be incorporated into the regional correction; the model extends only five kilometers in depth (upper crust) because there are no geologic constraints for the deeper subsurface and because the near surface features dominate the local surveys. Regional models were checked against the regional maps to make sure that calculated regional gravity conformed to the published values. 
Geophysical units used in modelling were drawn from many sources (Snavely and Wagner, 1964; Schlicker and others, 1972; Niem and Van Atta, 1973; Beeson and others, 1976b; Newton and Van Atta, 1976;

Tolson, 1976) and are listed in Appendix E. Although specific densities are assigned to each formation, the density contrast between formations is the fundamental concern for gravity work.

\section{RESULTS AND DISCUSSION}

\section{Fishhawk Falls-Denver Point}

Northwest of Jewe11, the $\mathrm{J}$ line runs $\mathrm{N} 61 \mathrm{~W}$ along a $3.75 \mathrm{~km}$ stretch of Oregon State Highway 202, which squarely intersects two approximately parallel linear dikes (Figure 17). Denver Point is underlain by a dike of low Mg (reversed) Depoe Bay chemistry which outcrops from station J59 to station 355 . Nearly two kilometers northwest, between stations J24-J2, is the outcrop of Fishhawk Falls, a low Mg (normal) Depoe Bay dike. The surrounding sedimentary rock units are mapped as 01 igocene to Miocene marine sedimentary rocks by Beaulieu (1973). The road follows Fishhawk Creek, which cuts both basalt bodies; tributaries to this creek intersect the gravity line at $J 75$ and $J 37-1 / 2$. Relief along the line is $85 \mathrm{~m}$ (elevation increasing from east to west), although it may be greater in directions normal to the stream valley in which the traverse 1ies. Magnitude of the initial terrain correction ranged from $.96 \mathrm{mga} 1$ to 1.43 mgals; adjustments for outcropping rock types of varying densities ranged from $-.01 \mathrm{mgal}$ to $.06 \mathrm{mgal}$.

A regional upper crust model along a N51W line of section, constructed for the $\mathrm{J}$ and Youngs River Falls lines, is $210 \mathrm{~km}$ long; $\mathrm{km} 0$ 


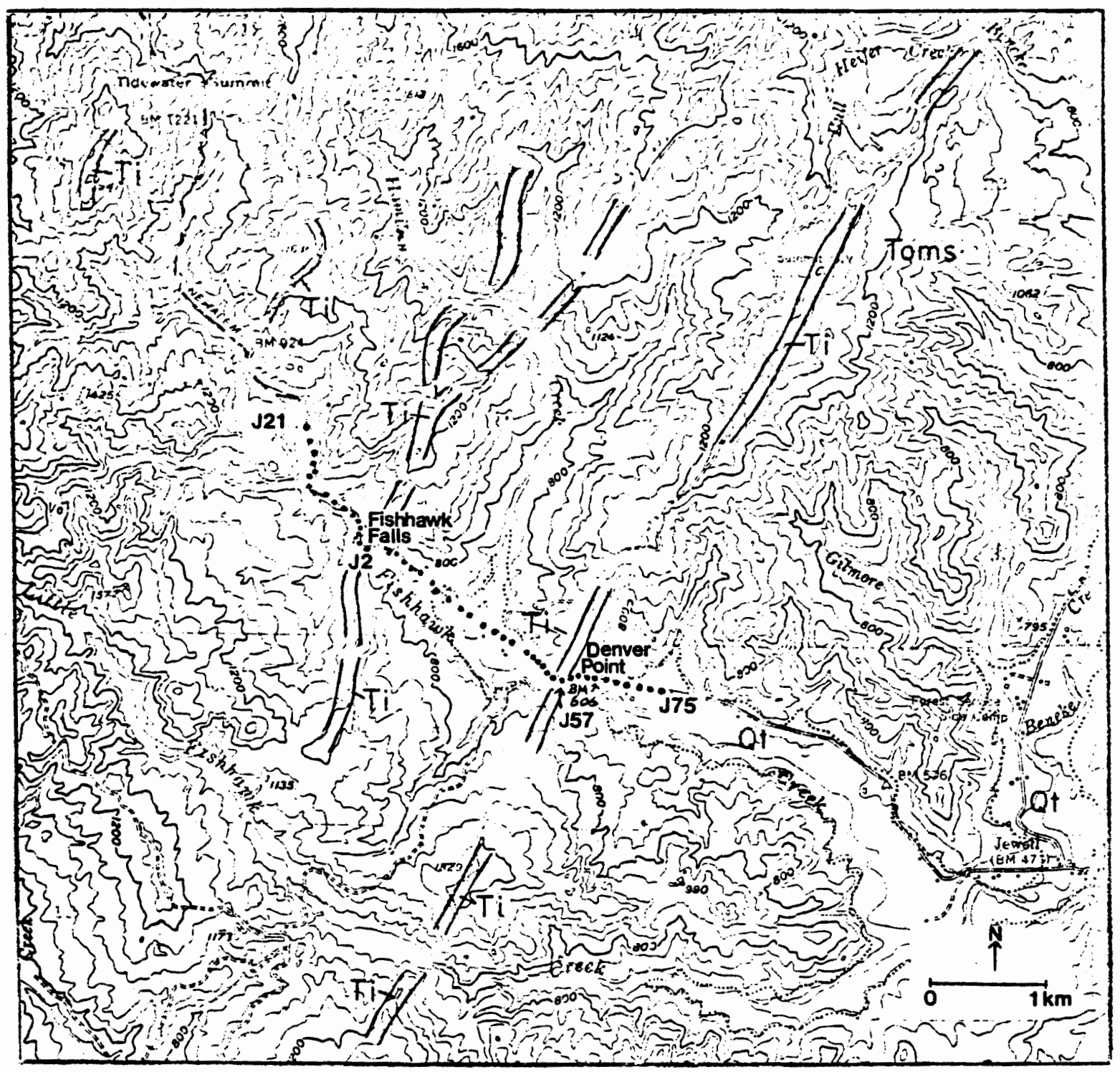

Figure 17. J line gravity traverse over Fishhawk Falls and Denver Point. (Geologic base map from Beaulieu, 1973).

is in the Tualatin Valley, $\mathrm{km} 110$ is the coastline, and $\mathrm{km} 210$ is northwest offshore. Geologic constraints were provided by well logs and other cross-sections (Figure 18). Four offshore exploratory test wells (Snavely and others, 1977) on the continental shelf distinguished between basalt and sediment and provided the depths to which sediments were encountered: well P-075 bottomed out at $3.1 \mathrm{~km}$ depth in basalt, 


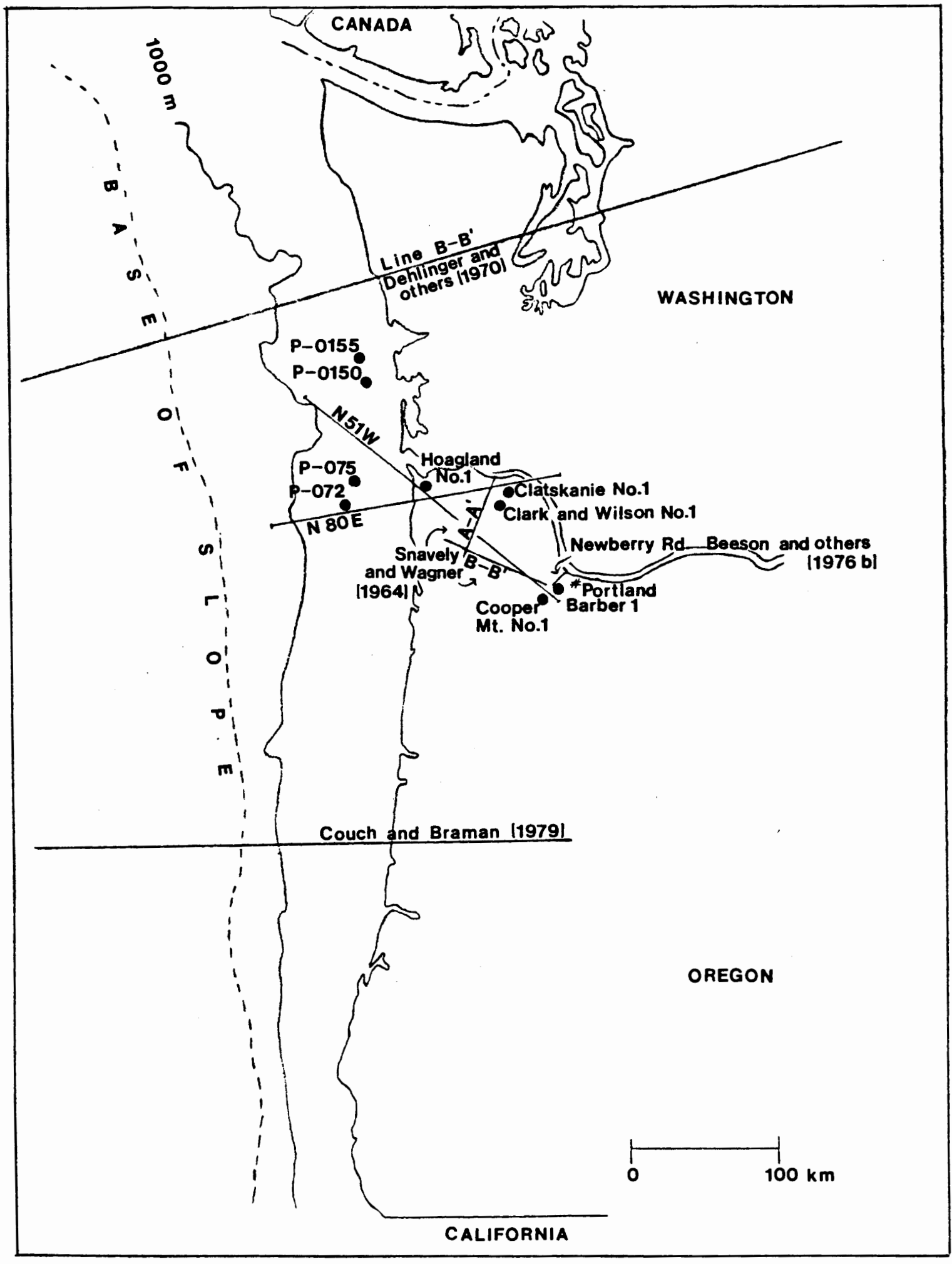

Figure 18. Locations of welis used in regional upper crust models. (Modified from Snavely and others, 1977). 
while wel1s P-072, P-0150, and P-0155 remained in sedimentary units throughout their total depths of $2.5 \mathrm{~km}, 4 \mathrm{~km}$, and $3.4 \mathrm{~km}$, respectively. Onshore well logs recorded by Newton (1969) include the $2.4 \mathrm{~km}$ deep Barber well in Portland, the $2.8 \mathrm{~km}$ deep Cooper Mountain No. 1 well in the Tualatin Valley, and the $2.2 \mathrm{~km}$ deep Hoagland No. 1 well in the Astoria basin. The Tertiary formations distinguished in these records became the basis for the selection of geophysical units in the mode1. Cross-sections $A-A^{\prime}$ and $B-B^{\prime}$ drawn across northwestern Oregon (Bromery and Snavely, 1964; Snavely and Wagner, 1964) intersect the N51W crustal section inland, as does a cross-section constructed by Beeson and others (Newberry Road, 1976b) controlled by the Barber and Cooper Mountain wells; cross-section $A-A^{\prime}$ in the Nehalem basin (Newton and Van Atta, 1976) between the $2.6 \mathrm{~km}$ deep Clark and Wilson No. 1 and the $1.7 \mathrm{~km}$ deep Clatskanie No. 1 provides additional control in the Nehalem basin. Bathymetry was taken from the Juan de Fuca Relief map (Price, 1977).

The subsurface between these control points was initially interpolated by correlation with straight lines; configuration of the units (primarily the Tillamook volcanics) was then adjusted to produce the regional gradient on the published state CBA map. Ideas for these adjustments offshore were suggested by geophysical cross-sections constructed in Dehlinger and others (1967) (especially section B-B' from the Tufts Abyssal Plain across the Puget Sound, Washington) and in Couch and Braman (1979) (through Florence, Oregon).

In order to generate the gradient observed at the coast, a fault $12.5 \mathrm{~km}$ inland was required, here made vertical; the position of this 
fault was later refined by modelling of the Youngs River Falls lines. This fault is probably the major northeast-trending fault at approximately $12 \mathrm{~km}$ inland mapped by Wells and Peck (1961), Schlicker and others (1972), and Tolson (1976), and may be related to the presumed N2OE-trending fault along the east side of a sediment-filled trough just offshore in this area (Zietz and others, 1971).

As constrained by the we 11 logs and the two-dimensional nature of the modelling program, this crustal section does not generate sufficient magnitude for the gravity high over the Tillamook Highlands. A model across the Tillamook Highlands (approximately parallel to the section constructed here) along Snavely and Wagner's (1964) X-X' cross-section adequately produced the required gravity high. The effect of this three-dimensional basalt mass was accounted for by gradients calculated from control points on the state maps: $1.973 \mathrm{mgals} / \mathrm{km}$ from 375 to $\mathrm{J} 49$ and $3.077 \mathrm{mgals} / \mathrm{km}$ from $\mathrm{J} 49$ to $\mathrm{J} 21$. The data collected along this traverse confirm the placement of the +20 mgals contour on the state map (Figure 15).

The absolute magnitude and gradient of the observed CBA was found to agree very closely with the control points and gradients provided by the state CBA map and calculated from the upper crustal model (Figure 19). The CBA is flat from $\mathrm{J} 75$ west to $\mathrm{J49}$, and then decreases steadily to the west. Two positive anomalies, both approximately $100 \mathrm{~m}$ wide, of .4 and .8 mgal corresponding to outcrops of basalt at Denver Point and Fishhawk Falls, respectively, and lows corresponding to stream valleys interrupt the regional trend. At these places, the outcrop density was known to vary from $2.67 \mathrm{~g} / \mathrm{cc}$ : outcrops of basalt $(2.8 \mathrm{~g} / \mathrm{cc})$ and alluvium 
แ 
$(2.0 \mathrm{~g} / \mathrm{cc})$.

A comparison of the observed CBA and the topography (Figure 19) suggests that the CBA overall has an inverse relationship to the topography, indicating that the reduction density of $2.67 \mathrm{~g} / \mathrm{cc}$ was too high. This is quite likely, as the density attributed to the near-surface sediments is only $2.4-2.5 \mathrm{~g} / \mathrm{cc}$. The elevation of the area, averaging $220 \mathrm{~m}$, provides a relatively thick infinite slab for the Bouguer correction, but the final analys is is independent of which density, 2.4 or $2.67 \mathrm{~g} / \mathrm{cc}$, is used because the basalt and alluvium densities are higher and lower than, respectively, either 2.4 or $2.67 \mathrm{~g} / \mathrm{cc}$. Presumably these anomalous rock masses above sea level were not adequately corrected for in the Bouguer correction.

The wavelengths of these residual CBA are on the order of $100 \mathrm{~m}$, requiring a near-surface source. Figure 20 illustrates the effect of infinite vertical dikes on the CBA: both the wavelength and the amplitude of the resulting anomalies are considerably greater than the observed values. The correspondence of residual anomalies with known anomalous rock masses and the fact that such rock masses do outcrop further indicates that the source is above sea level. Therefore it is appropriate to study the FAA rather than the CBA.

The observed FAA is plotted in Figure 21 . Notice that the residual anomalies of the CBA are reproduced on the FAA, supporting the nearsurface source for the anomalous masses. The FAA differs from the CBA in that it rather parallels the topography, being fairly level from $\mathrm{J75}$ to $\mathrm{J} 40$ and then increasing to $\mathrm{J} 2 \mathrm{I}$ on the west.

Topography for the FAA computer model was measured from the 
岕

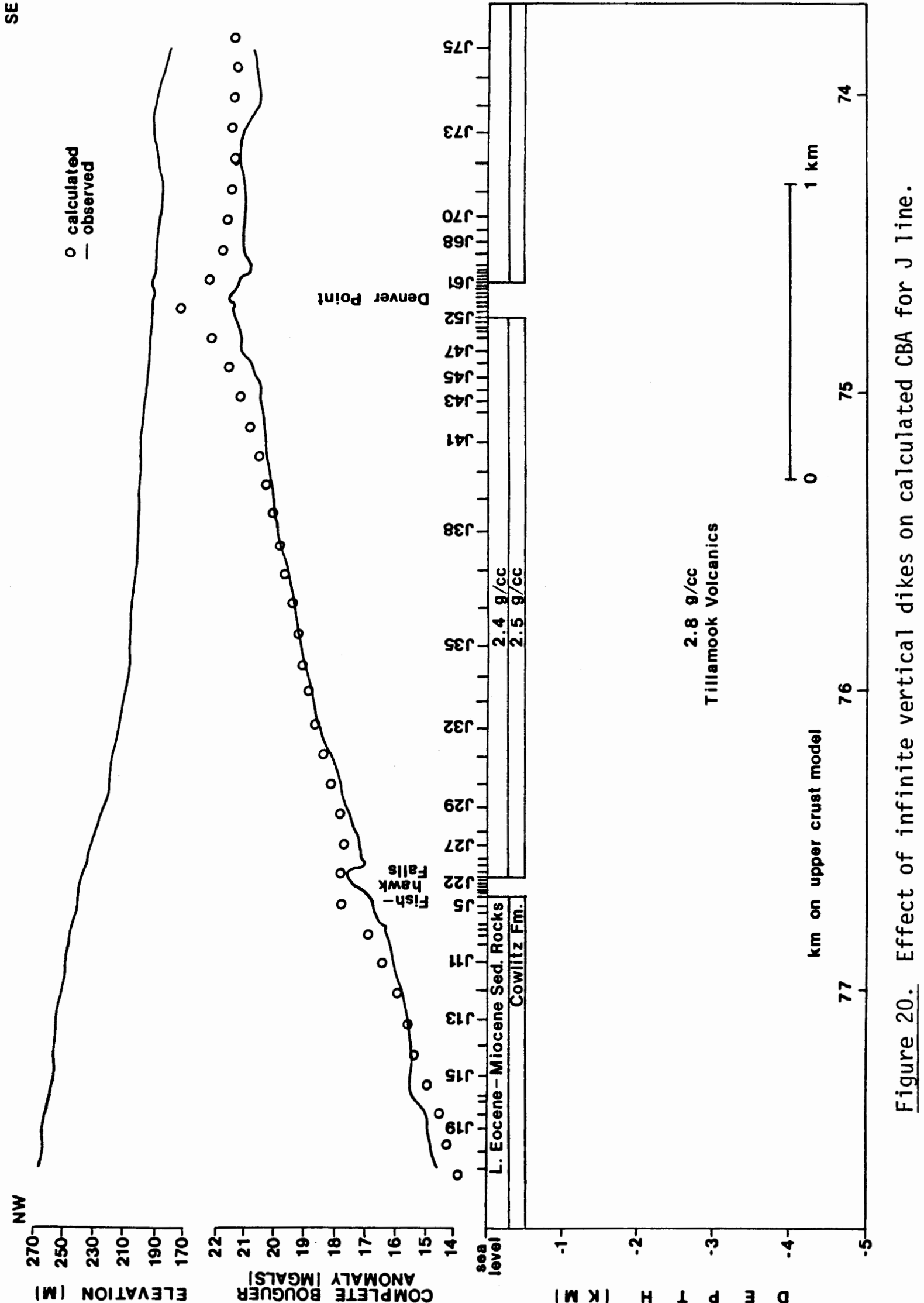


录

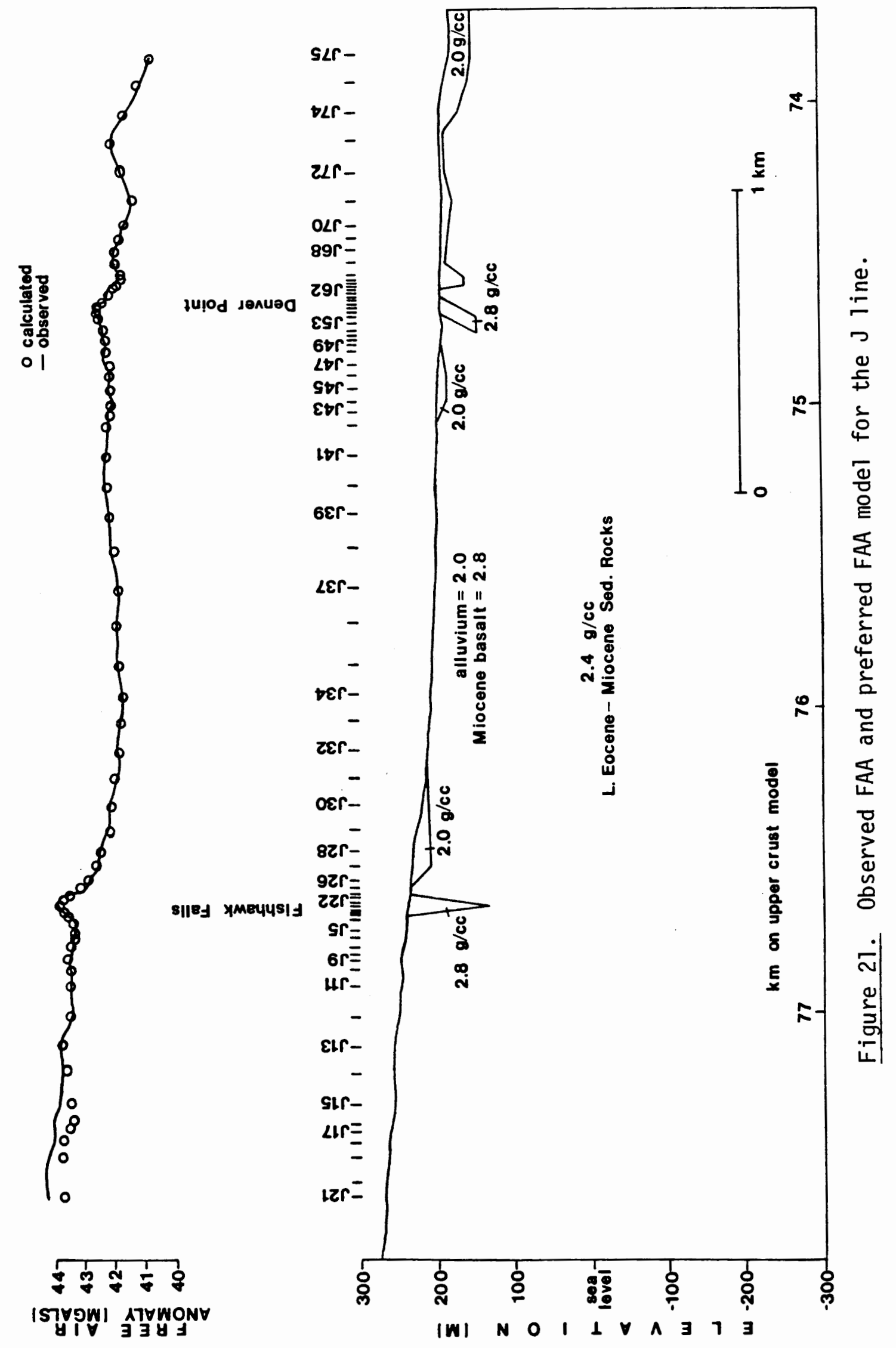


Vancouver and Hoquiam 1/4 million sheets along a N5TW 1ine except for km 65-km 85; this $20 \mathrm{~km}$ of topography was measured along a N61W line on the Saddle Mountain $15^{\prime}$ quadrangle and spliced into the N5IW regional model to give a more accurate topographic model for the 3 line. Geology for the FAA mode1 is after Wells and Peck (1961).

Because the modelling program considers only the two dimensions along the traverse, only the topography along the traverse can be modelled and its effect accounted for. This is particularly significant when the traverse is on a graded road in a stream valley with rugged topography on either side normal to the cross-section. To compensate for this, the terrain correction was calculated for all zones but using only those compartments not intersected by the $J$ line. These terrain corrections, ranging from .71 to $1.14 \mathrm{mgals}$, were calculated using a $2.4 \mathrm{~g} / \mathrm{cc}$ density to more nearly match the presumed surface densities and were also adjusted to account for surface densities known to vary from $2.4 \mathrm{~g} / \mathrm{cc}$. The values were used to correct the observed FAA rather than the calculated FAA as a convenience in the modelling procedure, although the calculated values are the ones theoretically being adjusted. Thiruvathukal and others (1970) found it necessary to correct their FAA for terrain to make the FAA more nearly independent of terrain effects.

Since the FAA model is a fine-tuning of the CBA model, the upper crusta 1 model and its attendant gradients must form the basis of the FAA model. The initial regional FAA model constructed by adding topography and geology above sea level to the regional upper crustal model was adjusted to compensate for the two-dimensional nature of the model and the three-dimensional nature of the Tillamook Highlands by gradients of 
$1.679 \mathrm{mga} 7 \mathrm{~s} / \mathrm{km}$ from $\mathrm{J} 75$ to $\mathrm{J} 49$ and $2.348 \mathrm{mgals} / \mathrm{km}$ from $\mathrm{J} 49$ to $\mathrm{J} 21$.

Figure 21 presents the preferred model for the $\mathrm{J}$ line. Unique solutions to observed gravity anomalies cannot be determined, but some subsurface geologic models can be ruled out. Models are designed to satisfy the observed gravity values while remaining as simple as possible within the bounds of geologic control.

Perhaps the most significant feature of this model is the shallow depths to which these dikes extend. The basalt at Fishhawk Falls (J24 to J2) appears to be a wedge-shaped dike $52 \mathrm{~m}$ wide at the surface and tapering to a point approximately $107 \mathrm{~m}$ below the surface at an elevation of $130 \mathrm{~m}$. A variety of different geometrical shapes (rectangles, parallelograms, triangles, and combinations) were modelled, but this "tooth" is required to produce the width at the peak of the anomaly without increasing the values at the base, i.e., to give the anomaly roughly parallel sides. Although the wedge tip is centered under the outcrop so the wedge does not dip, the sides converge downward with a basalt/sediment contact dipping $76^{\circ}$. Only slight adjustments for dip $\left(\leq 5^{\circ}\right)$ produce calculated anomalies still within the error range of the observed values. Changing the depth by $10 \mathrm{~m}$ produces a $.02 \mathrm{mgat}$ change.

The Denver Point outcrop (J59-J55) is $55 \mathrm{~m}$ wide and extends to a depth of $45 \mathrm{~m}$ below the surface. In the field at the west end from $\mathrm{J} 55$ to $\mathrm{J57}$, the basalt/sediment contact is nearly vertical and perpendicular to well-developed nearly horizontal columnar joints, and the observed residual anomaly seems to have a smaller superimposed anomaly from $\mathrm{J} 57$ to J55. A vertical basalt dike from J57-J55 extending $45 \mathrm{~m}$ down from the surface will approximately produce this smaller anomaly but will not pro- 
duce sufficiently high values at J59. The observed gravity anomaly is best matched by a dike dipping roughly $37^{\circ} \mathrm{W}$. The dip is required to produce the short levelling out on the residual anomaly at $J 59$ and to raise the calculated values to match the observed just west of 355 . To make the estimate of basalt volume maximum, the residual anomaly has been regarded as extending from $\mathrm{J} 59$ to $\mathrm{J55}$. Changing the depth of this dike by $10 \mathrm{~m}$ produces a $.05 \mathrm{mgal}$ change. If the true residual anomaly is in fact only the smal1 $30 \mathrm{~m}$ wide anomaly from J57-J55, the dike can be vertical and of less lateral extent and volume; perhaps the eastern part of the outcrop (J57-J59), which is more massive, is part of a large landslide from the north, or perhaps the more narrowly jointed dike is part of the large basalt mass, superimposed upon it as the smaller anomaly is upon the larger.

A block of low density material approximately $15 \mathrm{~m}$ deep (probably stream alluvium) is required from $\mathrm{J} 32-\mathrm{J} 25$ to produce the low observed just east of Fishhawk Falls. Modelling the basalt there as a vertical dike extending to sea level with the original CBA regional gradient will produce the observed FAA across Fishhawk Falls to J5, but at that point, the calculated values begin to drop to a final 1.2 mgals below the observed. Adding a subsurface basalt unit on the west end of the dike to raise the calculated values to those observed is not recommended as 1) no such subsurface anomalousiy dense masses are evident on the CBA while all evident anomalously dense masses do appear on the observed CBA, and 2) there is no geologic evidence for such a mass. Even then, this dike extends only to sea level in the model. Therefore, the possibility of a vertical dike is disregarded, and a block of lower density 
alluvium adjacent to a shallow wedge of basalt is preferred.

Low density material (stream alluvium) is also required on either side of Denver Point where tributaries to Fishhawk Creek meet the main creek. A tapering rectangle of $2.0 \mathrm{~g} / \mathrm{cc}$ material $31.5 \mathrm{~m}$ east of Denver Point, $75 \mathrm{~m}$ wide by $30 \mathrm{~m}$ deep, is reminiscent of a wide shallow stream valley and is interesting in its proximity to the basalt dike.

State Highway 202 curves sharply south around both dikes, running parallel rather than perpendicular to the dikes and thereby extending the portion of traverse adjacent to the basalt -- readings at these stations on the curve were influenced by the outcropping basalt, but when projected onto the N6IW I ine appear to be away from the basalt. This effect is difficult to evaluate and in this study has not been quantitatively taken into account.

Bulk density measurements made on a surface sample of Fishhawk Falls basalt yielded a density of $2.84 \mathrm{~g} / \mathrm{cc}, .04 \mathrm{~g} / \mathrm{cc}$ higher than the model's density of $2.8 \mathrm{~g} / \mathrm{cc}$. The higher density basalt would necessitate slightly less mass to produce the same magnitude anomaly; however, $2.8 \mathrm{~g} / \mathrm{cc}$ was used to produce a conservative estimate of the amount of subsurface basalt.

The CBA rules out other anomalous subsurface basalt masses within the plane of the profile, and the dikes are assumed to extend perpendicular to the profile. However, the possibility of thin feeder dikes extending vertically beneath these major dikes cannot be ruled out. The effect was model led for feeder dikes extending from $130 \mathrm{~m}$ elevation to sea level beneath Fishhawk Falls and having widths of 2, 12, and $22 \mathrm{~m}$. Terminating the basalt wedge at $130 \mathrm{~m}$ elevation with a base width of 
$2 \mathrm{~m}$ (rather than a point, as previously) increases the calculated gravity over Fishhawk Falls by up to $.03 \mathrm{mgal}$. A dike of this $2 \mathrm{~m}$ width extending to sea level increases the originally calculated gravity by $.04 \mathrm{mgal}$. A $12 \mathrm{~m}$ wide feeder dike increases the calculated values by up to $.13 \mathrm{mgal}$; a $22 \mathrm{~m}$ wide dike adds up to $.21 \mathrm{mgal}$ to the calculated values. Thus the gravitational effect of feeder dikes up to about $10 \mathrm{~m}$ width and extending to sea level (and presumably to the Tillamook volcanics) would be masked by that of the overlying mass of basalt; feeder dikes wider than approximately $10 \mathrm{~m}$ would have a definite effect on the observed gravity and thus can be ruled out. A smaller mass of surficial basalt underlain by a more substantial feeder dike would change the width of the anomaly.

The two positive residual anomalies on the $\mathrm{J} 1$ ine are produced by two shallow basalt dikes 55 and $52 \mathrm{~m}$ wide and extending 45 and $107 \mathrm{~m}$ below the surface, respectively. Other lateral basalt masses along the 1 ine of section are ruled out by the CBA. The effect of feeder dikes less than $10 \mathrm{~m}$ wide extending vertically beneath the basalt is masked by the overlying mass of basalt.

\section{Youngs River Fal1s}

Three kilometers south of the junction of the Klaskanine and Youngs Rivers, the Youngs River tumbles over a Cape Foulweather intrusion which has an arcuate shape and has been called both a ring dike and a cutoff oxbow meander (Figure 22). Perhaps because of this intriguing outcrop plan, plus the excellent access via a network of Crown Zellerbach logging spurs and a "host rock" of geophysically contrasting 01 igocene-Miocene 


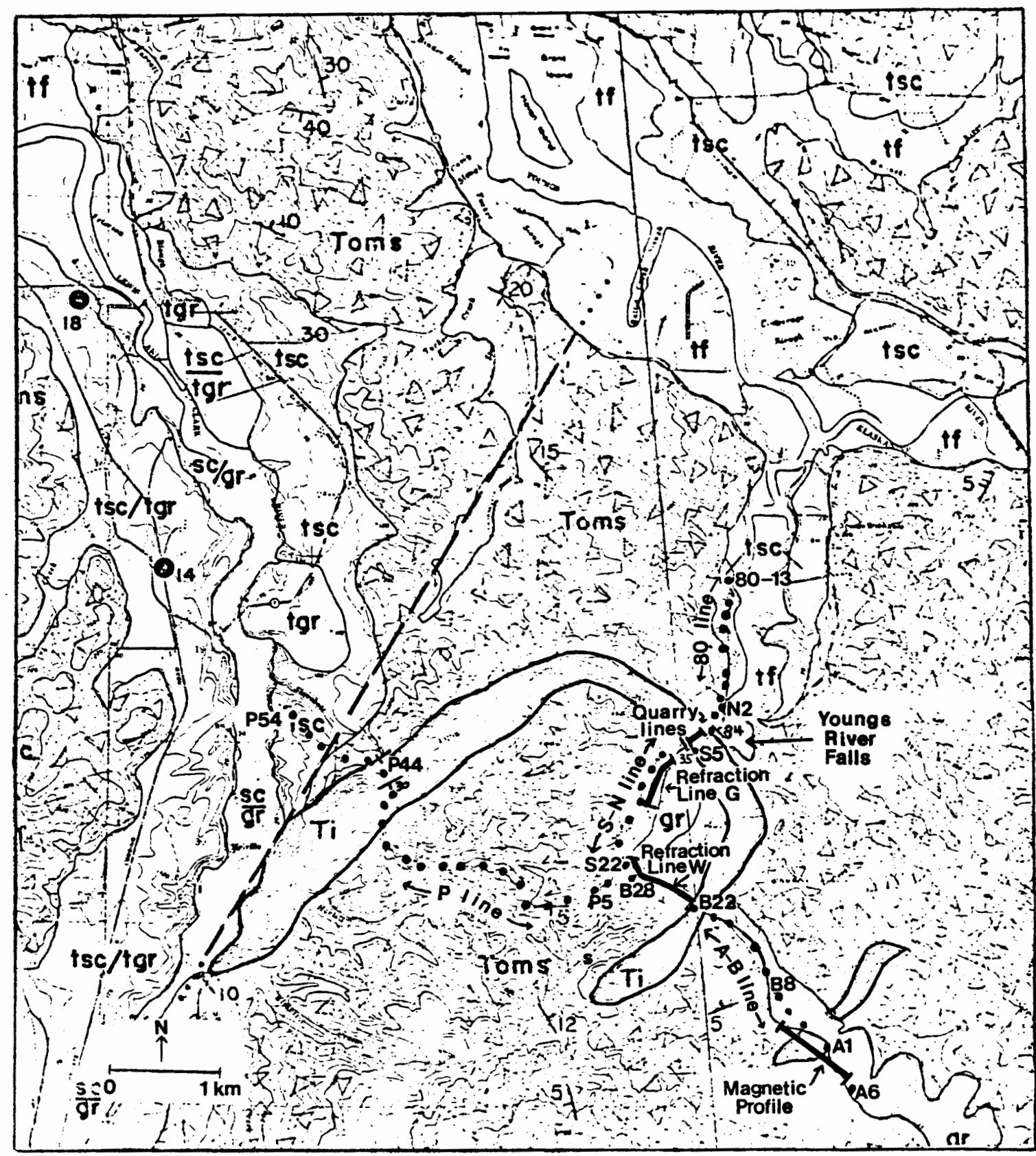

Figure 22. Youngs River Falls gravity traverses ( 1 ines $P$, $\overline{A-B}, S-N, 80$ ), refraction surveys ( 1 ines $Q, W, G$ ), and magnetic profile. (Geologic base map from Schlicker and others, 1972). 
sediment, the Youngs River Falls intrusion has been geophysically investigated more extensively than the other coastal basalt features in this study.

An entire (closed) "ring" has been mapped by Tolson (1976), although Schlicker and others (1972) show but a three-sided figure. The limbs of this $U$ extend NE-SW while the middle section is NW-SE. Youngs River crosses both the SE 1 imb and the middle section, as does the Crown Zellerbach Youngs River Mainline road. The Mainline road plus a series of logging spurs within the $U$ interior provide access across both limbs perpendicular to the axis; the Mainline road itself crosses the basalt parallel to the $U$ axis. Gravity surveys were conducted along these two perpendicular lines.

Along the Mainline road from the 400 line intersection southeast for $2.72 \mathrm{~km}$, A.G. Johnson, M.H. Beeson, M. Moran, and R. Perttu measured the 34 stations of line A-B. Stations A1-B3 $(176 \mathrm{~m})$ cross a smaller feature of abundantly phyric (Ginkgo) Cape Foulweather basalt (VP-10); B19-B22 (236 m) cross the SE $1 \mathrm{imb}$ (VP-7) of the U, a rarely phyric (Sand Hollow) Cape Foulweather sill. Continuing the line across the $U$ interior and NW 1 imb, the $P$ line (55 stations) runs for $3.21 \mathrm{~km}$ along spurs 400 , 490-A, and Stavebolt Road. The basalt of the NW Timb (VP-29) crops out for $20 \mathrm{~m}$ from $\mathrm{P} 42-1 / 2$ to $\mathrm{P} 43$. A11 reduced stations were projected onto a straight line (N5TW) normal to the 1 imbs. This total $5.9 \mathrm{~km}$ of gravity line was computer modelled.

For two years, the Portland State University Field Geophysics classes have run gravity 1 ines over the Youngs River Falls basalt. The 1979 class constructed the S-N traverse along the Mainline road from the 
400 line intersection northeast for $2.57 \mathrm{~km}$; stations $\mathrm{S} 2-\mathrm{S} 5-1 / 2(26.2 \mathrm{~m})$ cross the basalt middle section at the quarry (VP-6). The 1980 class extended the line one kilometer further with the "80" stations, making the total traverse parallel to the $U$ axis $3.57 \mathrm{~km}$ long. Each of the "80" stations was read twice on successive days by various class members, and the two sets of data were here reconciled and averaged. The best fit line to the data points and normal to the basalt is N59E.

The elevation is highest within the $U$ interior, which is roughly $100 \mathrm{~m}$ above the river valley. Relief along Youngs River is nearly $50 \mathrm{~m}$, decreasing steadily to the north. The terrain correction ranged from 1.41 to $3.8 \mathrm{mga} 7 \mathrm{~s}$ on the A-B 1 ine, .71 to $1.98 \mathrm{mgals}$ on the $P 1$ ine, and .94 to $2.08 \mathrm{mgals}$ on the combined $\mathrm{S}-\mathrm{N}-801$ ine; the magnitude of the correction for rock type varied from 0.0 to $.34 \mathrm{mgal}$ on the A-B line to 0.0 to $.20 \mathrm{mgal}$ on the $\mathrm{P} 1$ ine to 0.0 to $.03 \mathrm{mgal}$ on the $\mathrm{S}-\mathrm{N}-80 \mathrm{l}$ ine.

A1 1 lines were tied to a common local gravity base station, and previously established stations were reread in later surveys to establish internal consistency. Data reduction was carried out independently by each group of workers.

No control points were available on the published state maps to guide the CBA and FAA contouring in the Youngs River Falls area. The +10 mgals contour on the state CBA map was made to reflect rather closely the toe of the Tillamook Highlands, as the +20 mgals 1 ine does (Figure 15). However, both the P line data and S-N line data, which match the state map absolutely, now provide control for this area. The +10 mgals line more nearly parallels the 0 mgal contour, and accordingly should be swung into a northwest arc (Figure 15). This configuration 
enhances the gravity saddle evident for northwestern Oregon in the Nehalem basin.

The combined A-B-P line and $J$ line lie along the same northwest trend, and the regional upper crust used for the $J$ line was devised for the A-B-P line also; the geologic controls for this upper crustal model were described in the previous section. Because the $\mathrm{J}$ line and the $A-B-P$ line are underlain by the same model, the model-generated anomalies must be related to each other directly. The east end of the A-B-P line (A6) (13.71 mgals) nearly matches the west end of the J line (J21) (14.22 mgals) and its nearby control point (13.21 mgals); the models generating each line had to agree absolutely at this "common" flat bench of average $13.45 \mathrm{mgals}$.

The regional model required a fault to produce the steep dropoff in gravity at the coast; a fault at $\mathrm{km} 97.5$ (P49-1/2) as mapped by Schlicker and others (1972) approximated the regional pattern adequately for use on the $\mathrm{J}$ line. However, the additional detail provided by the $P$ line requires the fault to be relocated, as the fault at $\mathrm{km} 97.5$ is not supported by geologic or topographic evidence, or by the observed $P$ 1 ine CBA curvature. Creating a steep slope at the west end (P27-P46) and meeting the observed values to the east (across the $U$ interior and SE limb to A6) was best accomplished by a fault near $\mathrm{km} \mathrm{97.15.} \mathrm{Tolson}$ (1976) mapped a fault at $\mathrm{km} 97.154$ (P45), a topographic break with in the sedimentary rocks but underlain by Eocene volcanics, so the regional fault was place there. The fault is assumed vertical.

The CBA calculated from the revised regional upper crustal model is compared to the observed data in Figure 23. From the east (A6), the 
岕

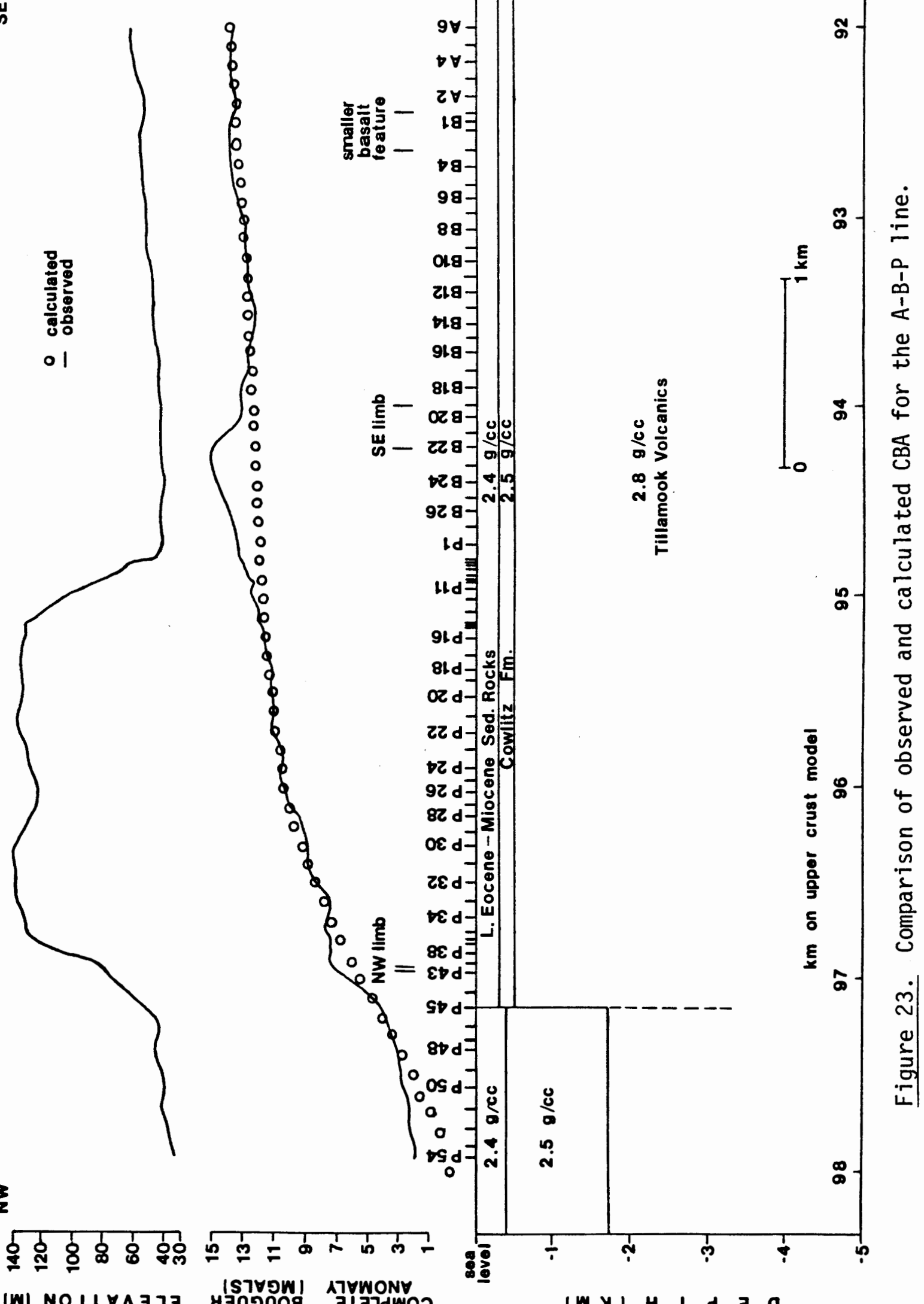

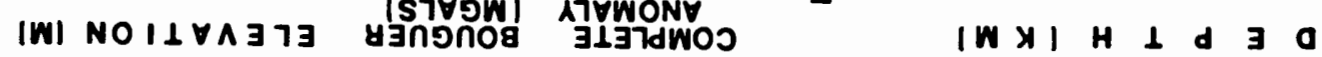


values decrease steadily, roughly $3 \mathrm{mgals}$ over the first $4 \mathrm{~km}$; over the final $2 \mathrm{~km}$, the values decrease steeply, dropping nearly 9 mgals but seeming to begin levelling off by P54. A residual anomaly over the smaller basalt feature to the southeast measures $600 \mathrm{~m}$ by $.5 \mathrm{miga} 1$. A substantial anomaly over the SE 1 imb of the $U$ is roughly $1 \mathrm{~km}$ by $2 \mathrm{mgals}$. The anomaly over the NW $1 \mathrm{imb}$ is superimposed on the sharp western drop, but would appear to be $500 \mathrm{~m}$ by $1 \mathrm{mgal}$ (?).

Deviations of the trend of the calculated values from the trend of the observed values were assumed to result from small defects in the model and were corrected with gradients rather than with juggling of subsurface blocks. The eastern $1.22 \mathrm{~km}$ was raised a total of $.88 \mathrm{mgal}$, increasing to the east; the western $1.83 \mathrm{~km}$ was lowered a total of 2.79 mgals, decreasing to the west. The final calculated $400 \mathrm{~m}$ falls away from the observed, but this was ignored as it is a function of the gradient and does not affect the basalt. This solution for the fit of the model to the observed data creates a maximum basalt anomaly.

Figure 24 illustrates the effect of infinite, vertical dikes on the CBA. The smaller, southeast basalt feature is seen to be neither infinite nor vertical. Over the SE limb, the vertical dike produces the acceptable amplitude, but the calculated peak is offset from the observed peak, indicating that the feature is not vertical. Over the NW 1 imb, the $20 \mathrm{~m}$ outcrop of basalt extended vertically does not produce a significant anomaly; more subsurface basalt is needed to produce the apparent CBA residual anomaly, or the residual anomaly will have to be reconsidered.

Figure 25 illustrates the observed FAA. Over the eastern $2.7 \mathrm{~km}$, it resembles the CBA: generally decreasing, with a $400 \mathrm{~m}$ by $.5 \mathrm{mgal}$ 
w

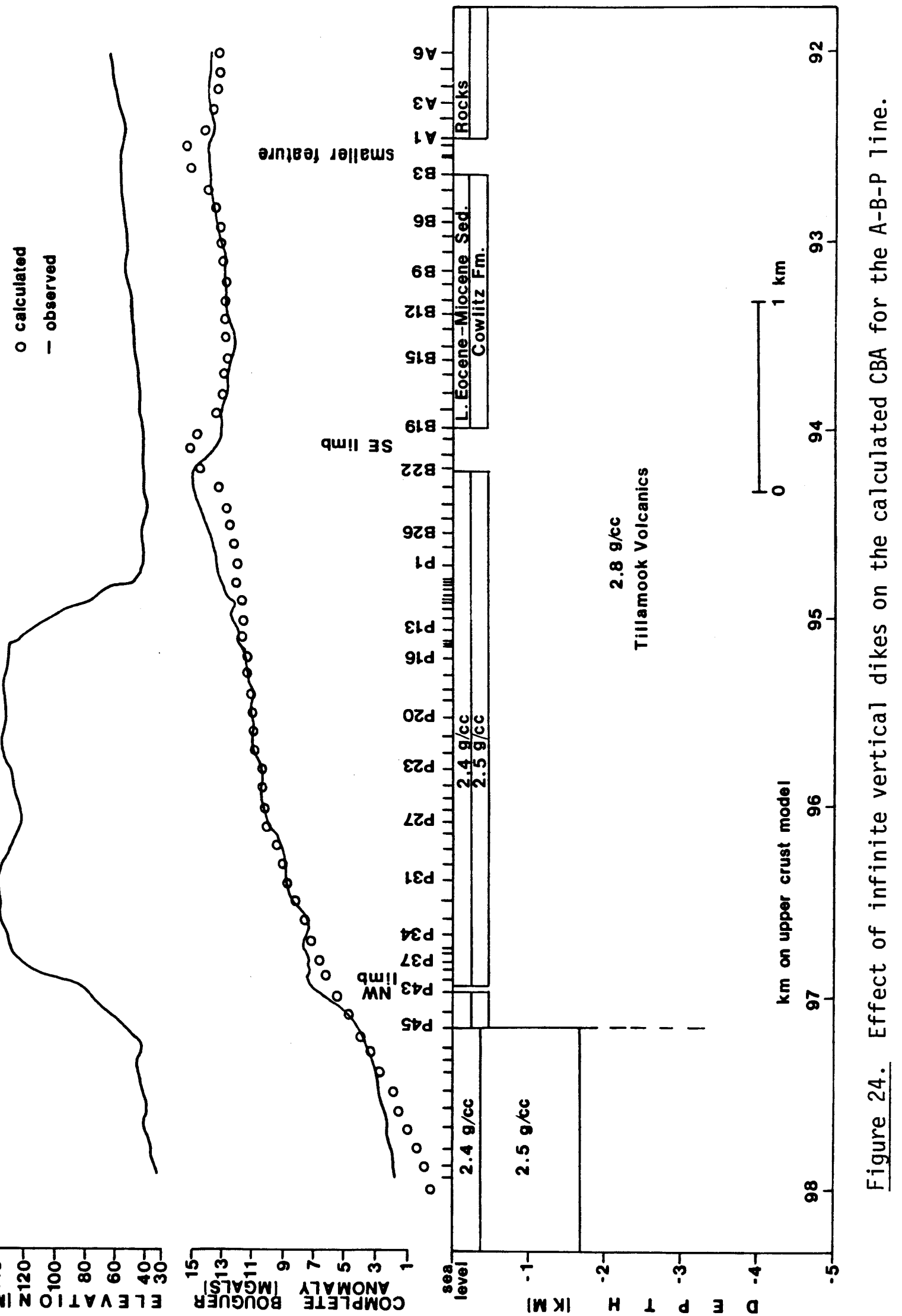




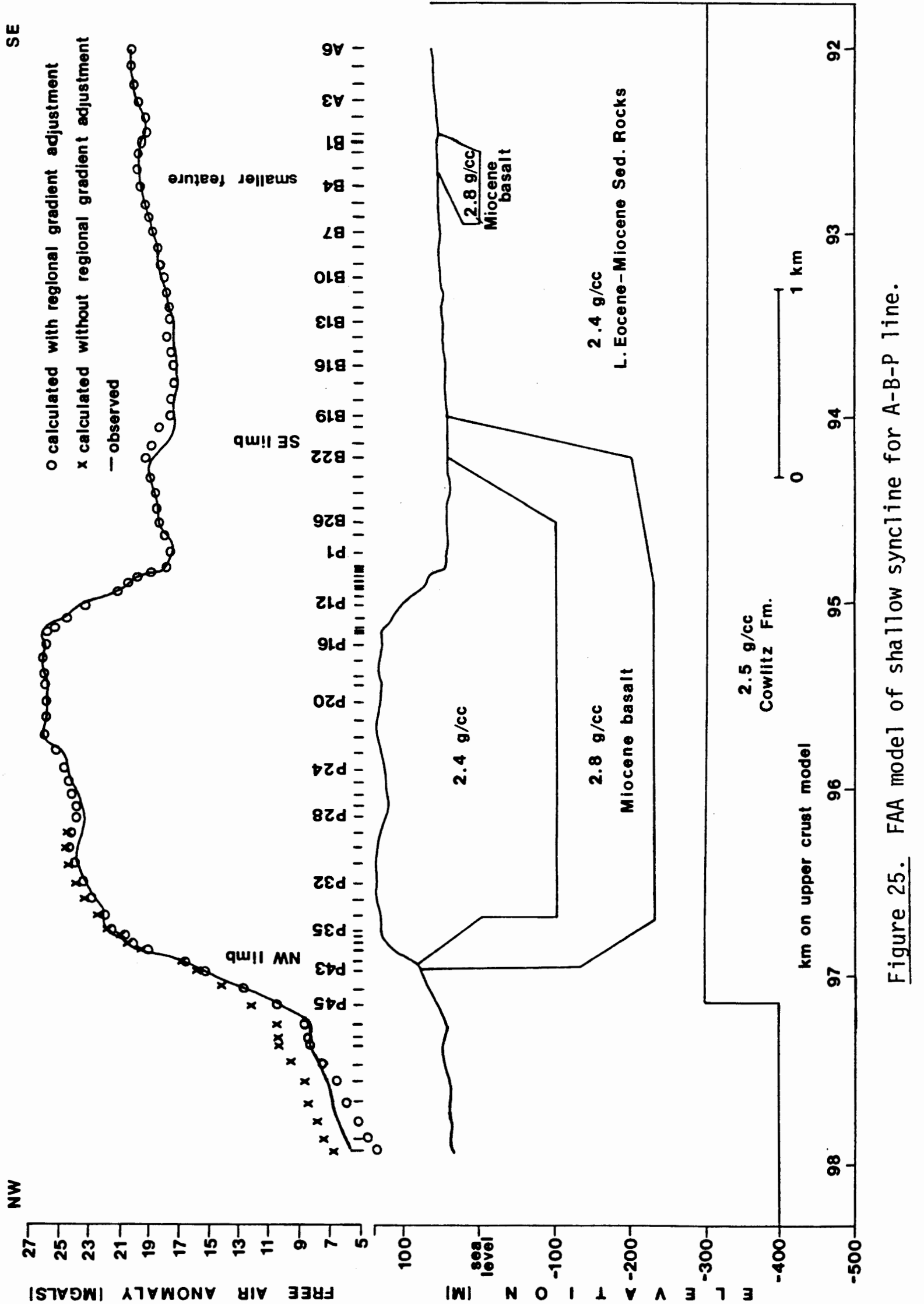


anomaly over the little feature and a $650 \mathrm{~m}$ by $1.8 \mathrm{mgals}$ anomaly over the SE Timb. Then, however, the values climb steeply (8.7 mgals) from the west side of the SE limb for nearly a kilometer; the topography rises steeply there also. Approximately $1.5 \mathrm{~km}$ further west, both FAA and topography begin to drop off sharply. (13.6 mgals and $90 \mathrm{~m}$ over $500 \mathrm{~m}$ horizontally), levelling out somewhat over the final $700 \mathrm{~m}$. Effects, if any, of the NW limb superimposed on this slope are not apparent.

In comparing the observed $C B A$ and observed $F A A$ : The little feature to the southeast has the same shape on both curves but has a larger amplitude on the FAA; it is not evident on the topography. The SE $1 \mathrm{imb}$ has the same shape on both and approximately the same amplitude on both; it is not evident on the topography. The NW $1 \mathrm{imb}$ appears more pronounced on the CBA while being elongated on the FAA to the point of seeming not to be there. As on the FAA, the NW Timb is not evident on the topographic profile.

The lack of correspondence between either the CBA or the residual FAA and the topography suggests that the reduction density of $2.67 \mathrm{~g} / \mathrm{cc}$ was not a bad overall estimate. Positive residual anomalies that show up on both the FAA and the CBA were not, however, sufficientiy corrected for by the Bouguer correction at $2.67 \mathrm{~g} / \mathrm{cc}$. These outcropping basalt features were modelled for the FAA initially; the CBA upper crustal model was then modified as the FAA modelling dictated. The FAA regional model was constructed as described in the previous section for the $\mathrm{J}$ line; one regional model fit both traverses. The regional model produces the trend of the observed FAA using the same gradients and reasoning as used for the CBA. 
As before, the observed values were adjusted for terrain effects not along the line of survey and therefore not included in the model. The amount of terrain correction along the traverse ranged from .09 to $.47 \mathrm{mgal}$ for the $P$ line, .11 to $.37 \mathrm{mgal}$ for the $A-B$ 1 ine, and .08 to $.60 \mathrm{mgal}$ on the $\mathrm{S}-\mathrm{N}-80 \mathrm{line}$; the FAA was corrected by 1.2 to $3.0 \mathrm{mgals}$ on the $A-B$ line, .70 to $1.38 \mathrm{mgals}$ on the $\mathrm{S}-\mathrm{N}-80 \mathrm{line}$, and .48 to 1.46 mgals on the $P$ line.

The observed FAA data indicate, as did the CBA data, that adjustments of the state gravity contours are necessary (Figure 16). The +10 mgals contour should be swung further west to reflect the 0 mgal contour; the high FAA values between P8 to P45 are probably a local high over the $U$ interior.

Since the elevation of the Youngs River Falls area is near sea level, the added effect of vertical dikes above sea level to the previously discussed effect of infinite vertical dikes below sea level is not significant. Thus the local residual FAA which can be isolated and modelled suggest: 1) the smaller feature is relatively shallow and limited in lateral extent; 2) the SE $1 \mathrm{imb}$ is dipping west and is underlain by a considerable mass of basalt; 3 ) the NW 1 imb is inherently difficult to see because of the regional changes.

The basalt at Youngs River Falls is intriguing in the variety of subsurface configurations its map pattern suggests. One distinct possibility is the underground connection of the two limbs, for example, as part of a ring dike or as a plunging syncline. One such FAA model is shown in Figure 25.

The SE limb dips west, thickening with depth as the inner, north- 
west contact dips more shallowly $\left(22^{\circ}\right)$ than the outer, southeast contact $\left(37^{\circ}\right)$ to sea level, below which the outer contact steepens to a $50^{\circ}$ dip. The NW 1 imb dips asymmetrically to the east; the inner, southeast contact dips $17^{\circ}$ while the outer, northwest contact is somewhat arbitrarily made vertical to a depth below sea level of $130 \mathrm{~m}$, below which it dips $68^{\circ} \mathrm{E}$. The connecting basalt slab is $130 \mathrm{~m}$ thick between $100 \mathrm{~m}$ to $230 \mathrm{~m}$ below sea level.

The westward dip on the SE limb is required to shift the calculated anomaly peak west of the outcrop as observed. If the whole mass dips $45^{\circ}$ west and is $90 \mathrm{~m}$ thick, not enough mass will be west of B22, so the anomaly peak will not be shifted far enough and the western side of the anomaly will drop off two times too fast. Similarly, if the southeastern contact is made vertical, as it may be in the field, the anomaly is not shifted far enough west. If the basalt all dips $22^{\circ} \mathrm{W}$, not enough mass underlies the anomaly and no significant anomaly is generated. The residual anomaly is asymmetrical, rising more steeply on the east and gently on the west. This, too, is reflected in the correspondingly steeper eastern dip and shallower western dip. Thus asymmetrical dips satisfies both retaining the mass of basalt under the anomaly area while shifting the peak west.

If the connecting slab is to be shallow, it must not mask the observed separation (low) between the SE limb residual anomaly and the steep gradient rising from PI with the topography. At the same time, slab thickness must be maintained to produce the observed high across the $U$ interior where the model otherwise falls 1.8 mgals short of the observed values. The model presented is a minimum depth and minimum 
thickness estimate. Shallow slabs (50 m thick between $.20-.25 \mathrm{~km}$ below sea level or .25-.30 km below sea level) fall at least $1.5 \mathrm{mgals}$ short of the observed anomaly over the $U$ interior. A $100 \mathrm{~m}$ thick slab between .2-.3 km below sea level falls only .4 mgal short, but has added too much basalt under the $1 \mathrm{imb} ; 200 \mathrm{~m}$ of basalt between $.1-.3 \mathrm{~km}$ below sea level produces too much anomaly at the $U$ interior (.8 mgal high) and at the SE limb (.35 mgal too high) while also eliminating the separation between them. A $100 \mathrm{~m}$ thick slab between .1-.2 km below sea level retains the limb anomaly but is not massive enough (.4 mgal low) across the $U$ interior. Thus to achieve the observed anomaly across the $U$ interior, keep the slab shallow, and produce the distinctly separate residual anomaly across the SE $1 \mathrm{imb}$, the connecting slab had to be $130 \mathrm{~m}$ thick between $.1-.23 \mathrm{~km}$ below sea level. In addition, the basalt underlying the SE limb had to be undercut, i.e., the lower east corner had to be rounded to produce the observed anomaly. The calculated fit to the observed was also improved by "rounding" the upper and lower corners under the NW $1 \mathrm{imb}$.

Locating the anomaly produced by the NW 1 imb was a problem, as the gradient on the west slope of the $U$ interior is very steep. Although the selected model reproduces this gradient, not as much confidence can be attached to it. Figure 25 illustrates the effect of removing the regional gradient originaliy added to compensate for defects in the model. This model without a gradient is also a possible solution, as it matches the observed at some points and further adjustments might be expected to produce an even better fit. Either with or without the western regional gradient, the model essentially depicts a fault on the western 
margin of the NW $1 \mathrm{imb}$.

The small feature to the southeast can be modelled entirely above sea level. It, too, dips asymmetrically to the west, as does the residual FAA. The southeast contact dips $30^{\circ}$ down to sea leve1; the northwest contact dips very gently $\left(5^{\circ}\right)$ for $325 \mathrm{~m}$ and then drops vertically to sea level. This rather thin $(25-50 \mathrm{~m})$ and wide $(175-450 \mathrm{~m})$ general shape was not adjusted further. Initial modelling attempts had determined that a $25 \mathrm{~m}$ thickness fell .1 mgal short of matching the observed anomaly and that the mass of basalt west of B3 is necessary to allow the anomaly to fall off gently. Eliminating the "tongue" of basalt west of B3 so that the western margin parallels the eastern from B3 to sea level means that the calculated values will be up to .2 mgal below the observed between B4 to B7.

The Youngs River Falls basalt was also modelled with the connecting slab at its maximum depth, limited by the Eocene volcanics at $500 \mathrm{~m}$ below sea leve1. A deeper slab of basalt will have to be thicker $(200 \mathrm{~m})$ to produce the same effect at the surface. Figure 26 illustrates the FAA produced by a preliminary model. The calculated curve matches the observed curve fairly well except over the SE limb; this excess mass could no doubt be eliminated by further manipulation of the subsurface block.

The fault originally placed at $\mathrm{km} 97.154$ (P45) does not juxtapose geophysically contrasting units on the surface as originally modelled and is therefore of no local gravitational significance. Figure 27, however, shows the effect of a $.1 \mathrm{~g} / \mathrm{cc}$ density contrast across this fault, $2.4 \mathrm{~g} / \mathrm{cc}$ on the east side as consistent with the rest of the surficial sediments and $2.3 \mathrm{~g} / \mathrm{cc}$ on the west near the river alluvium. The 
岁

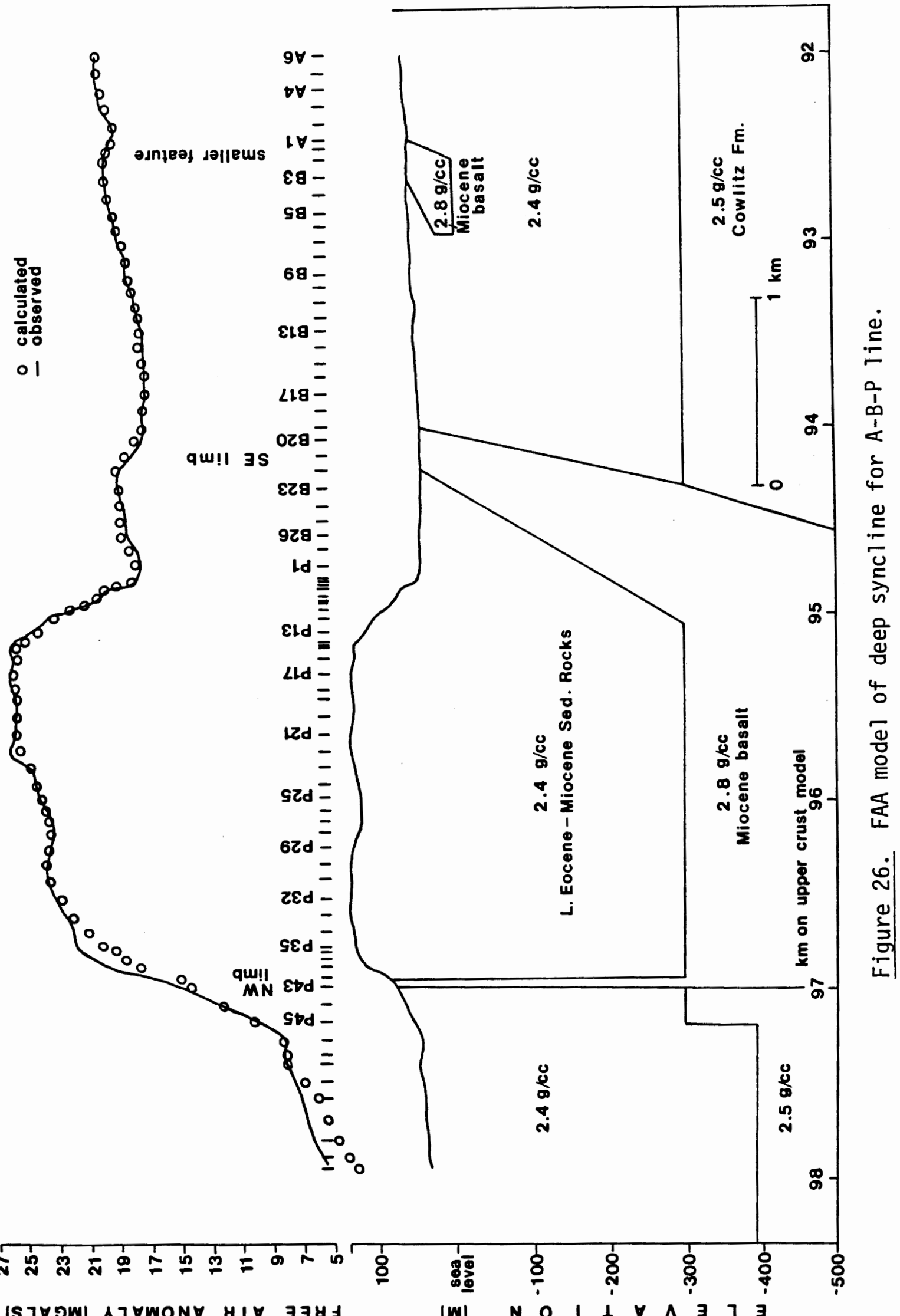




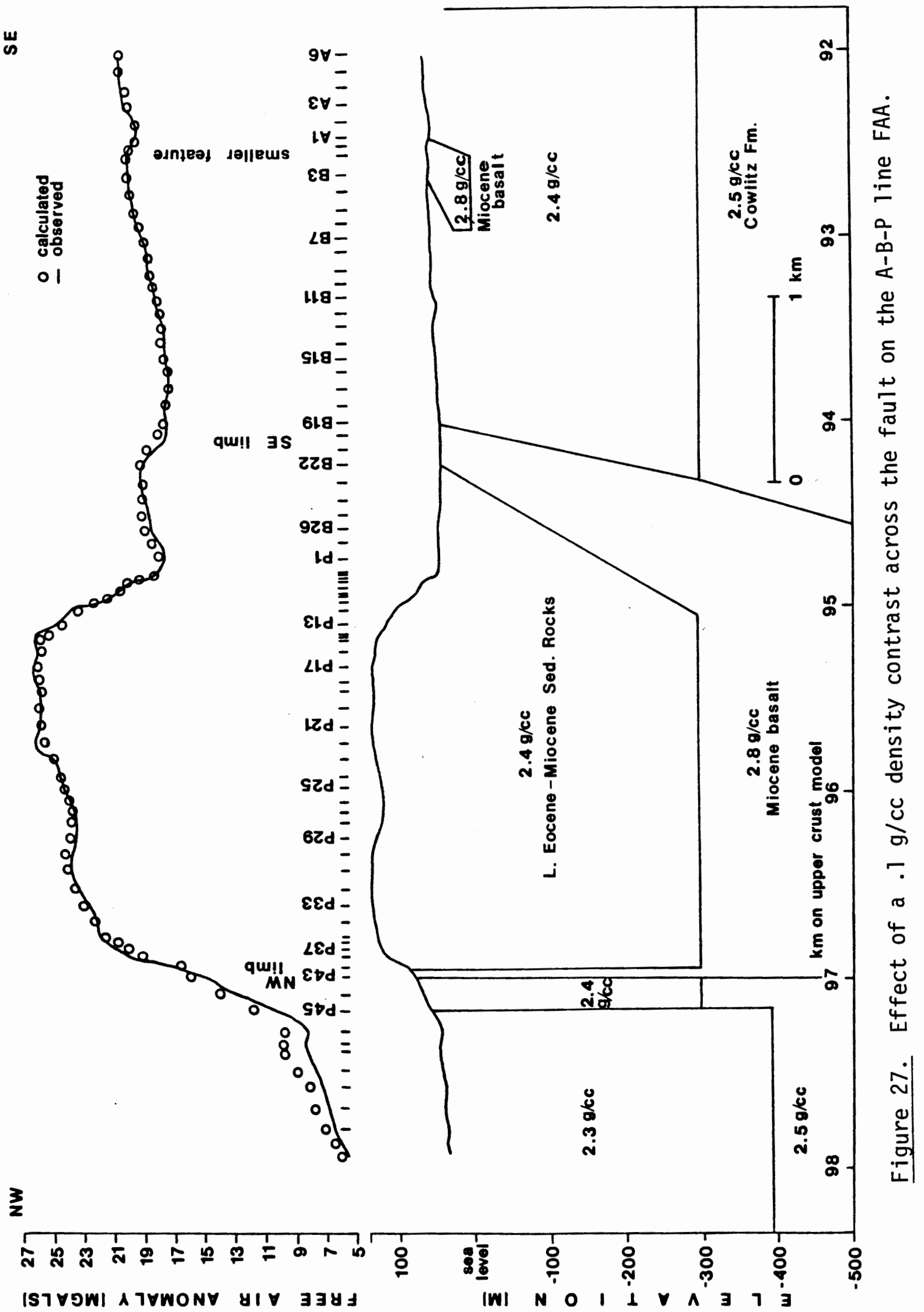


regional gradient was eliminated for this and other surficially faulted models. The values west of the fault as calculated by this arrangement are up to .2 mgal lower than values calculated from simply having the original deep syncline without a gradient (Figure 26). No evidence is available to give preference to either model.

The anomaly calculated from the elevation data over a uniformly dense sedimentary terrain (assuming a linear regional gradient) does not produce a high enough anomaly over the sedimentary rocks within the $U$ to match the observed (1.8 mgals higher), and a denser mass must be included under this area. The foregoing models of basalt slabs under the $U$ (Figures 25 and 26) serve not onty to model synclines but also to provide the extra gravitational attraction. However, one alternative for producing the gravitational high over the $U$ interior without adding extra basalt would be to argue that the basalt-encircled hill of sediments itself is denser than the surrounding sediments. Tolson (1976) remarked that the sediments are locally well-indurated near the basalt intrusion, implying that the bulk of the sedimentary rocks within the $U$ are not we1l-indurated. The fact that there is a hill of sedimentary rocks at all might argue that they must be more resistant to erosion and therefore perhaps denser, probably stewed by the surrounding basalt lava. The 01 igocene to Miocene sedimentary unit of Schlicker and others (1972) is one of the least resistant to erosion and usually has subdued topographic expression unless held up by an igneous center (Schlicker and others, 1972).

A model of such a dense hill is shown in Figure 28 . Each basalt limb extends $200 \mathrm{~m}$ below sea level, and all the sedimentary rock between 
$\underset{\infty}{\omega}$

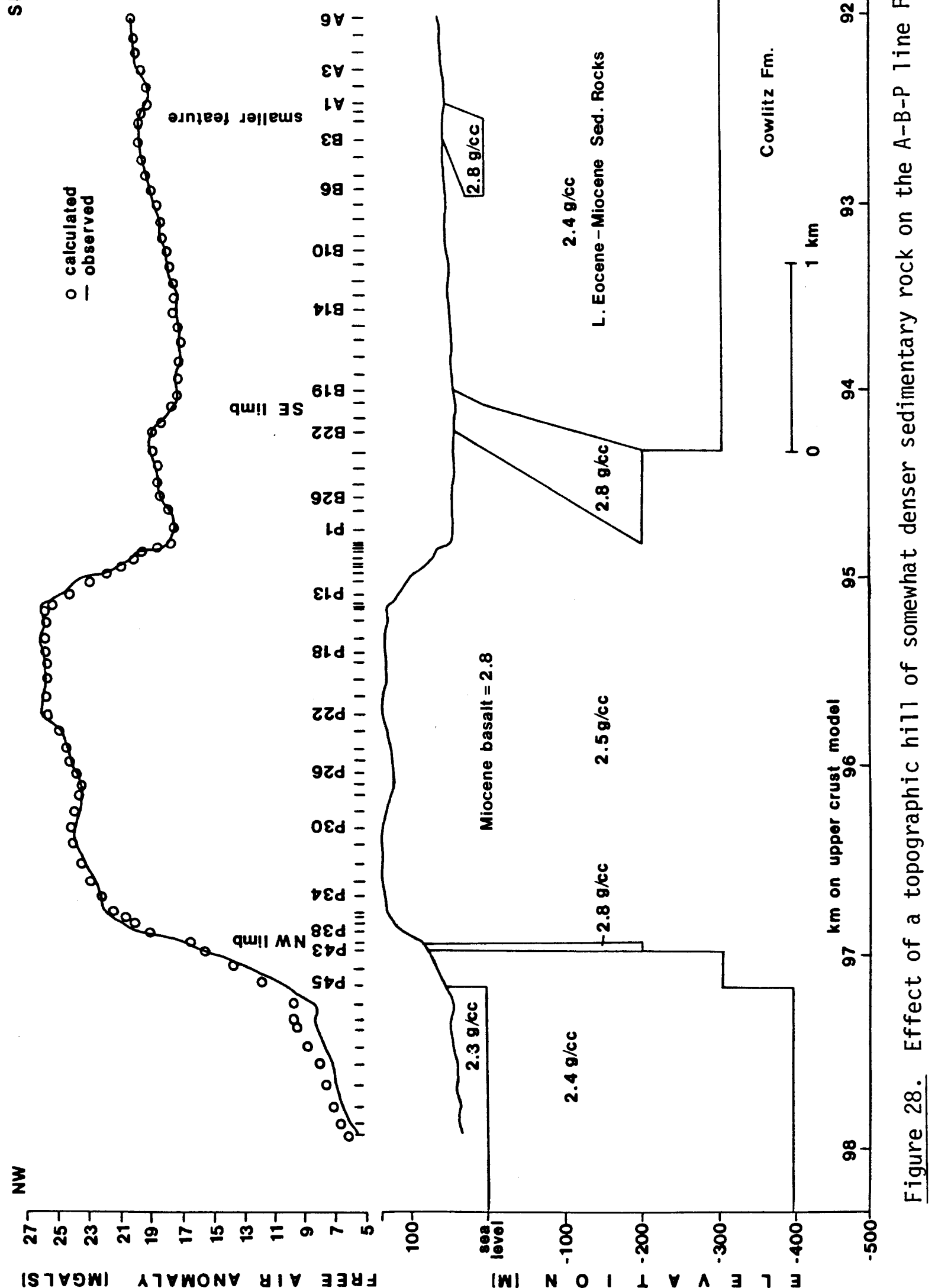


is of $2.5 \mathrm{~g} / \mathrm{cc}$ density $(.1 \mathrm{~g} / \mathrm{cc}$ higher than usual). Denser sediments were necessary to $300 \mathrm{~m}$ below sea level to produce the residual FAA high, as denser sediments only to sea level fell 1 mgal short of the observed anomaly. These models assume that the fault at $\mathrm{km} 97.154$ juxtaposes $2.5 \mathrm{~g} / \mathrm{cc}$ on the east with $2.4 \mathrm{~g} / \mathrm{cc}$ on the west.

A density of $2.8 \mathrm{~g} / \mathrm{cc}$ was assumed for the basalt throughout the coastal area. However, density measurements made on surface samples of the Youngs River Falls quarry basalt were $2.96-2.97 \mathrm{~g} / \mathrm{cc}$ (this study) and $2.95 \mathrm{~g} / \mathrm{cc}$ (Schlicker and others, 1972). If this basalt is indeed significantly denser, it would require less mass to produce the same anomaly. The residual anomaly over the SE $1 \mathrm{imb}$ is roughty $2 \mathrm{mgals}$, and at a density contrast of $.4 \mathrm{~g} / \mathrm{cc}$, the basalt mass should be approximately $300 \mathrm{~m}$ thick when the $1 \mathrm{imb}$ alone is considered. If the contrast then were $.55 \mathrm{~g} / \mathrm{cc}$, only $215 \mathrm{~m}$ of basalt would be needed to produce a $2 \mathrm{mgal}$ anomaly, which would lead to a slightly different subsurface and a lesser volume of basalt.

The Field Geophysics classes' S-N-80 Tine crosses the $U$ at the quarry. Since the southwestern continuation of this N59E trend intersects the N51W 1 ine at station P16, stations PI to P16 were projected onto the N59E line to extend it as far southwest as possible. Figure 29 illustrates the CBA and FAA observed along this traverse.

Hand calculations indicate that a semi-infinite slab approximates the CBA over the quarry. The estimated average residual $C B A$ of 4.85 mgals requires a $365 \mathrm{~m}$ thick basalt slab at a $.4 \mathrm{~g} / \mathrm{cc}$ density difference; the slab terminates abruptly at its northeast contact (S2) (J. Oggerino and R. Rudnick, pers. comm., 1980). 

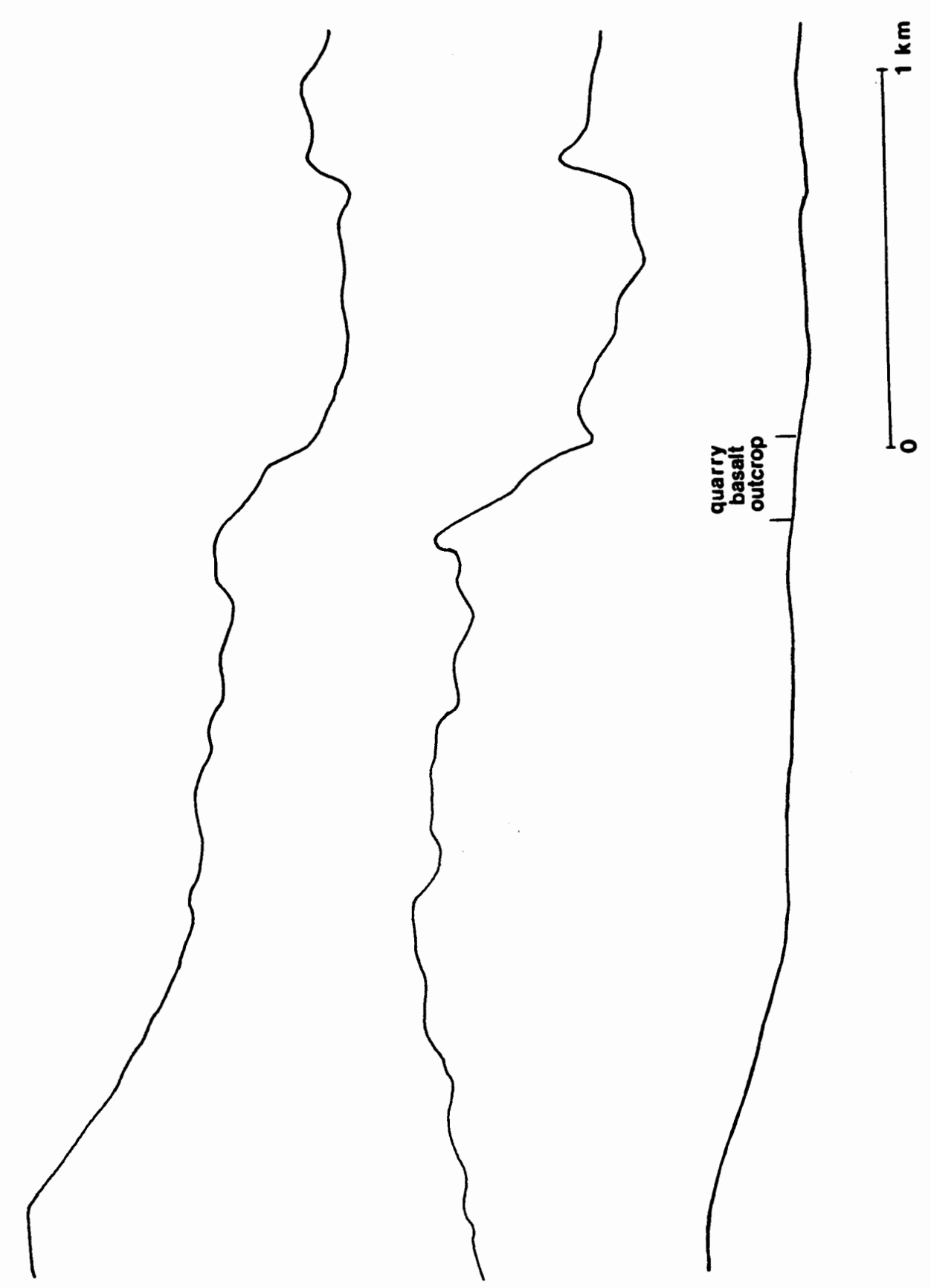

E1-08$4.08=$ 6-08-

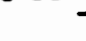
L-OB 9-08S-08 $\boldsymbol{t N}=$ IN ZN= $\ln =$

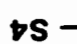

95

$95=$

85 -

-

OLs -

2tS -

HS -

or -

9LS -

8LS -

025 =

225 -

$2 d-$

$\checkmark d=$

$9 d=$

$8 d=$

Old $=$

$\rightarrow$

ud-

Eld-

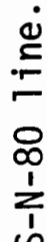

똔

5

4

近

므

宓

20

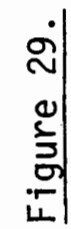

3

ง

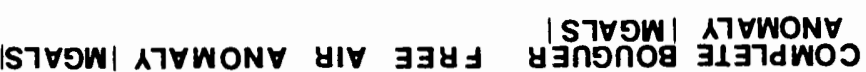

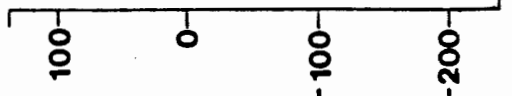

|Sษ 
Both the residual CBA and FAA over the SE 1 imb were of the same width and magnitude over a topographicaliy level area. The residual FAA over the quarry is considerably greater (by $2.15 \mathrm{mgals}$ ) than the residua1 CBA. However, the increasing gravity values from west to east across the quarry are accompanied by a $20 \mathrm{~m}$ increase in elevation, which probably accounts for the greater magnitude of the FAA. As the elevation over the quarry is so close to sea level $(10-30 \mathrm{~m})$, the residual FAA should be approximately equal to the residual CBA, and the $365 \mathrm{~m}$ thick basalt slab should be applicable to a FAA model as well. This estimate agrees with the $340 \mathrm{~m}$ thickness calculated for the SE 1 imb alone.

The CBA and FAA values southwest of the quarry (S6 to P16) remain high rather than dropping back to the local base level observed on the northeast side of the quarry. The consistently lower values northeast of the quarry suggest that the basalt does not continue northeast of the $U$. The northwest end of the $P$ line and the northeast end of the $S-N-80$ line are underlain by the same structure: both are superimposed on a rising regional gradient as they approach the $U$ interior. This is reflected in the steep increases of the CBA and FAA of both lines. The arguments made for the A-B-P line are applicable to the $\mathrm{S}-\mathrm{N}-80$ line also: either a denser mass (basalt or sediments) or a regional gradient must be model led to keep the gravity values elevated when in the $U$ interior, away from the known outcrop of basalt.

A magnetic survey with a proton precession magnetometer was made across the smaller feature by the 1979 Field Geophysics class. The smoothed data (Figure 30), corrected for drift but not elevation, indicate a 350 gamma by 300 foot anomaly. Preliminary estimation of the 


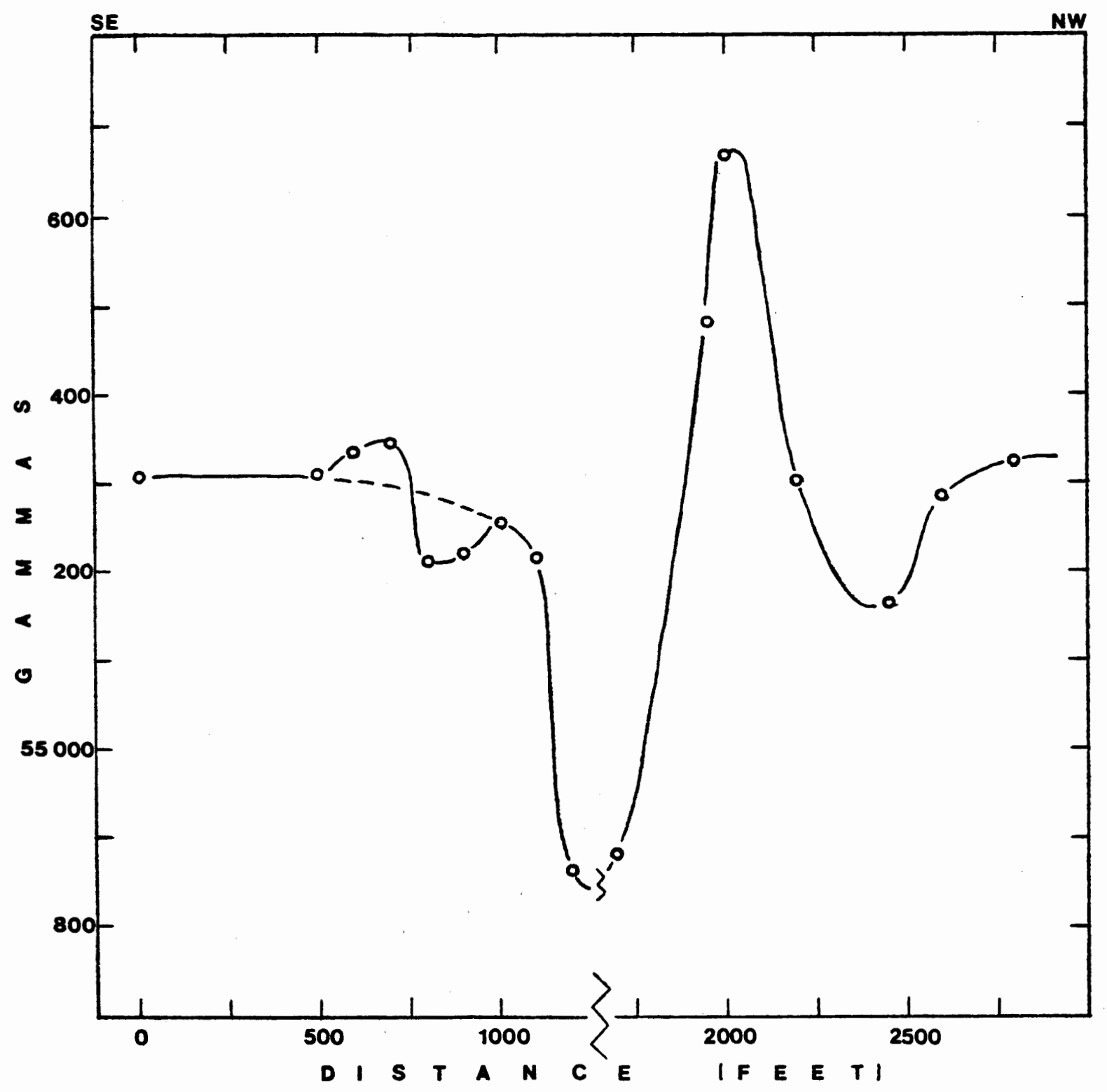

Figure 30. Magnetic profile over small basalt feature southeast of Youngs River Falls.

depth to the center of the magnetic source based on half-width considerations is $30-38 \mathrm{~m}$, which is in general agreement with the gravity thickness of $54 \mathrm{~m}$ with a center $27 \mathrm{~m}$ deep.

Refraction lines were run by the 1979 Field Geophysics class on the $U$ interior and the SE 1 imb (Figure 22). The velocity of the basalt 
was measured as 15-16,000 feet per second ( $f p s$ ) using short reversed hammer shots on the quarry bench (this study) (Figure 31). An 1850 foot long line with 50 foot spacing entirely within the $U$ (S8-S16) revealed an 11,700 fps layer at a 300 foot average depth dipping very gently $\left(2^{\circ}-3^{\circ}\right)$ southwest (Figure 32$)$. This velocity is considerably less than that of the basalt and is here interpreted as a denser interbed within the Astoria Formation or perhaps the underlying mudstones. In the gravity models for the $U$ interior, basalt did not extend above $100 \mathrm{~m}$ below sea level, which is below this 300 foot interface with the high speed sedimentary rock. The southeast end of a second line, 2200 feet long, was anchored on the northwest edge of the SE 1imb, i.e., just inside the $U$. On short (10 foot) geophone spacings adjacent to the basalt outcrop, a high speed (14,200 fps) layer was encountered at a 16 foot depth on the southeast end, dipping $6^{\circ} \mathrm{NW}$ (Figure 33 ). This high speed layer could be the basalt (slightly weathered or fractured) or a wellindurated sedimentary layer adjacent to the basalt. Its northwest dip agrees with the dip direction for the basalt based on gravity data. The 50 foot spacing on this line did not encounter such a high speed layer but again found an 11,800 fps layer dipping $3^{\circ} \mathrm{SE}$ at an interface depth of roughly 300 feet (Figure 34 ). The residual FAA overlaps this refraction line, and a basalt dike dipping shallowly $\left(22^{\circ}\right)$ northwest should be encountered by a 50 foot-spaced refraction line adjacent to the outcrop. Models for the Youngs River Falls A-B-P line were limited by the necessity of elevating the calculated values across the $U$ interior. One underlying assumption was that the positive residual anomaly over the interior is superimposed on a linear gradient. An aeromagnetic survey 


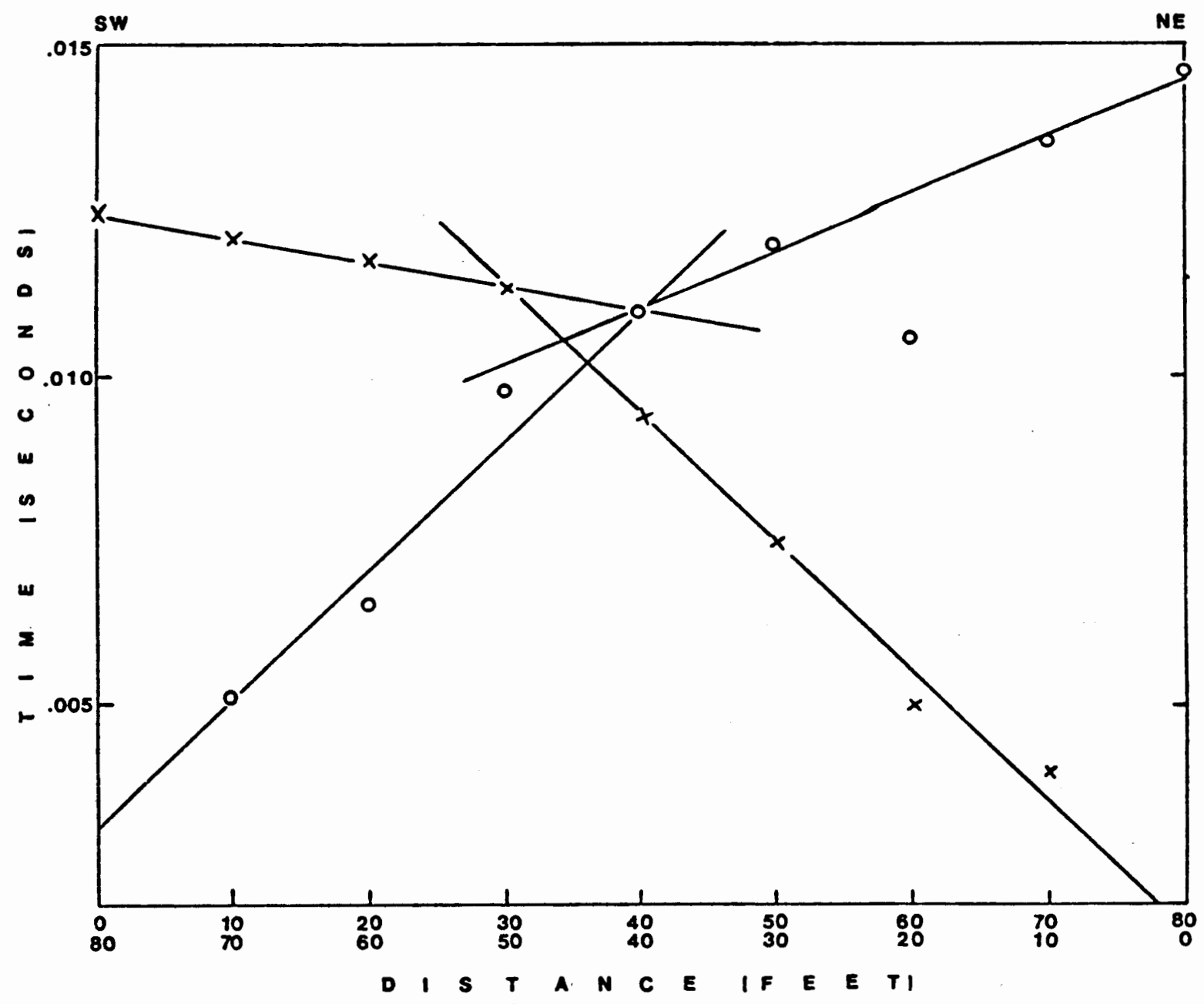

Figure 31. Refraction line measuring velocity of the basalt at Youngs River Fal ls quarry.

conducted by Snavely (unpublished, reproduced in Tolson, 1976) shows a local magnetic high roughly over the $U$ along the line of the gravity survey (Figure 35); in profile, the data reveal a nearly symmetrical feature of approximately 215 gammas by $4.2 \mathrm{~km}$ (Figure 36 ). The halfwidth indicates a depth to the magnetic source approximately $1.5 \mathrm{~km}$ below the survey altitude of $.61 \mathrm{~km}$, or $.89 \mathrm{~km}$ below sea level, which corresponds to Eocene basalt. Such data suggest a structural local high in the Eocene basalt, which could result in a structurally-controlled 


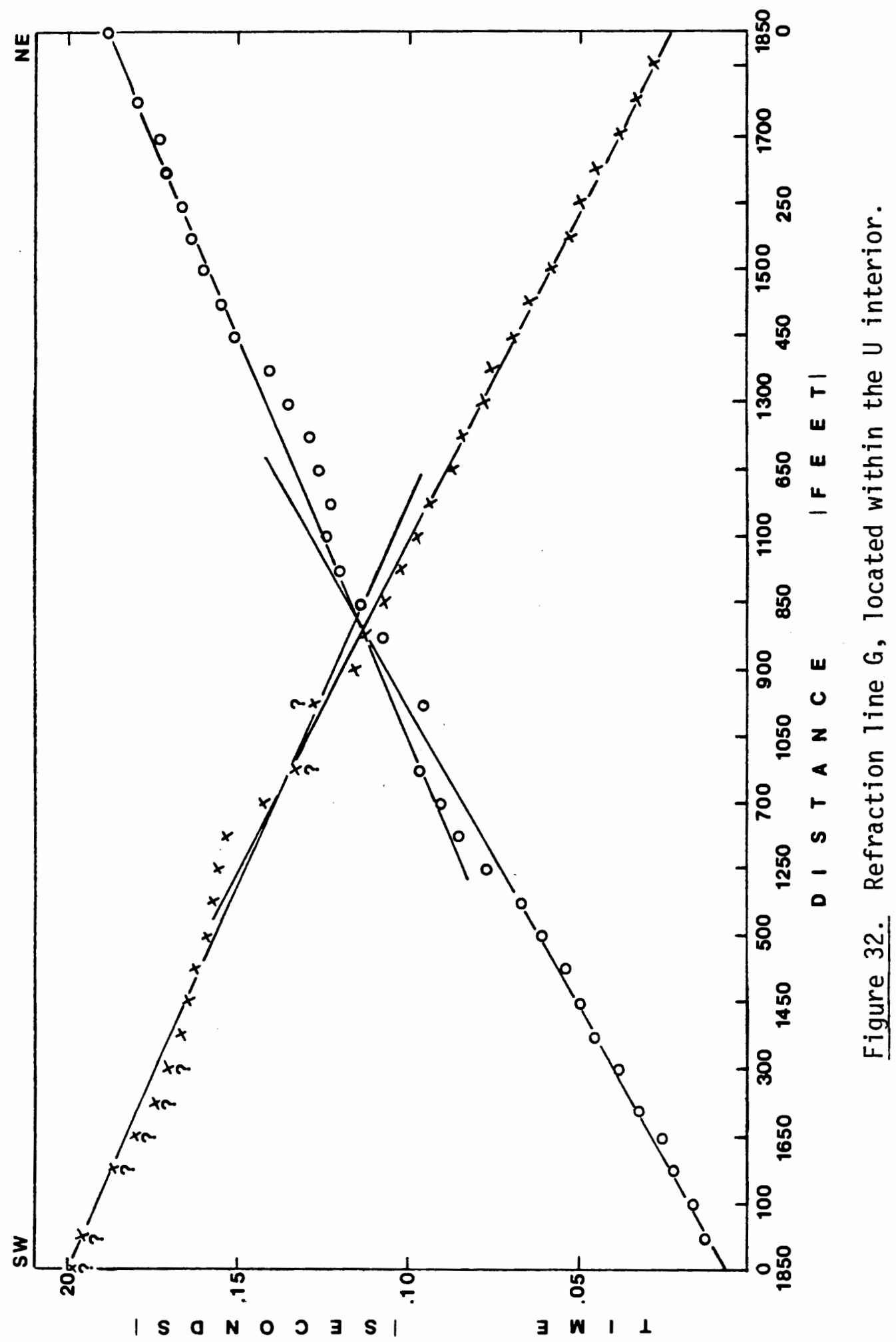




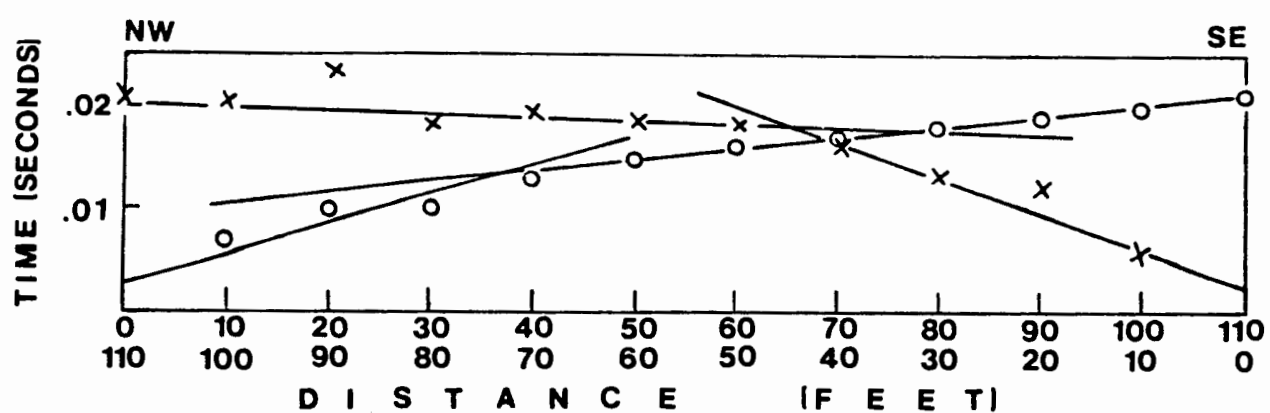

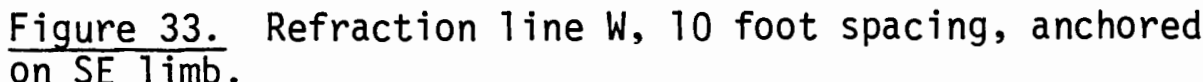
gravity high over the $U$ interior. If this is the case, neither denser sedimentary rocks nor a subsurface basalt layer would be necessary to model the residual anomaly over the $U$. One might then speculate that the Eocene structural high controlled the course of the lava flow around to the north, and thus, too, the gravity contours. The decreasing gradient on the northwest side of this magnetic anomaly steepens after a break in slope about $275 \mathrm{~m}$ northwest of the $\mathrm{NW} 1 \mathrm{imb}$; the steep gradient suggests the previously mapped and modelled fault.

Ring structures observed on the Columbia Plateau have been interpreted as sag flow out structures (McKee and Stradling, 1970) and as the result of interaction of lava with water (Hodges, 1978). These ring dikes are of small scale (50-500 $\mathrm{m}$ diameter, 1-3 $\mathrm{m}$ thick); they dip outward7y $\left(35^{\circ}-75^{\circ}\right)$ and may form topographic highs up to $15 \mathrm{~m}$ above the surroundings. Gravity surveys over three ring dikes (Parks and Banami, 1971) reveal the rings to be associated with negative anomalies of -1 mgal and half-widths of $120 \mathrm{~m}$. Although all the scales are smaller for these plateau ring dikes, and the plateau rings occur in basalt whereas the Youngs River Falls ring occurs in sedimentary rock, perhaps the most significant difference between Youngs River Falls and plateau (or any 


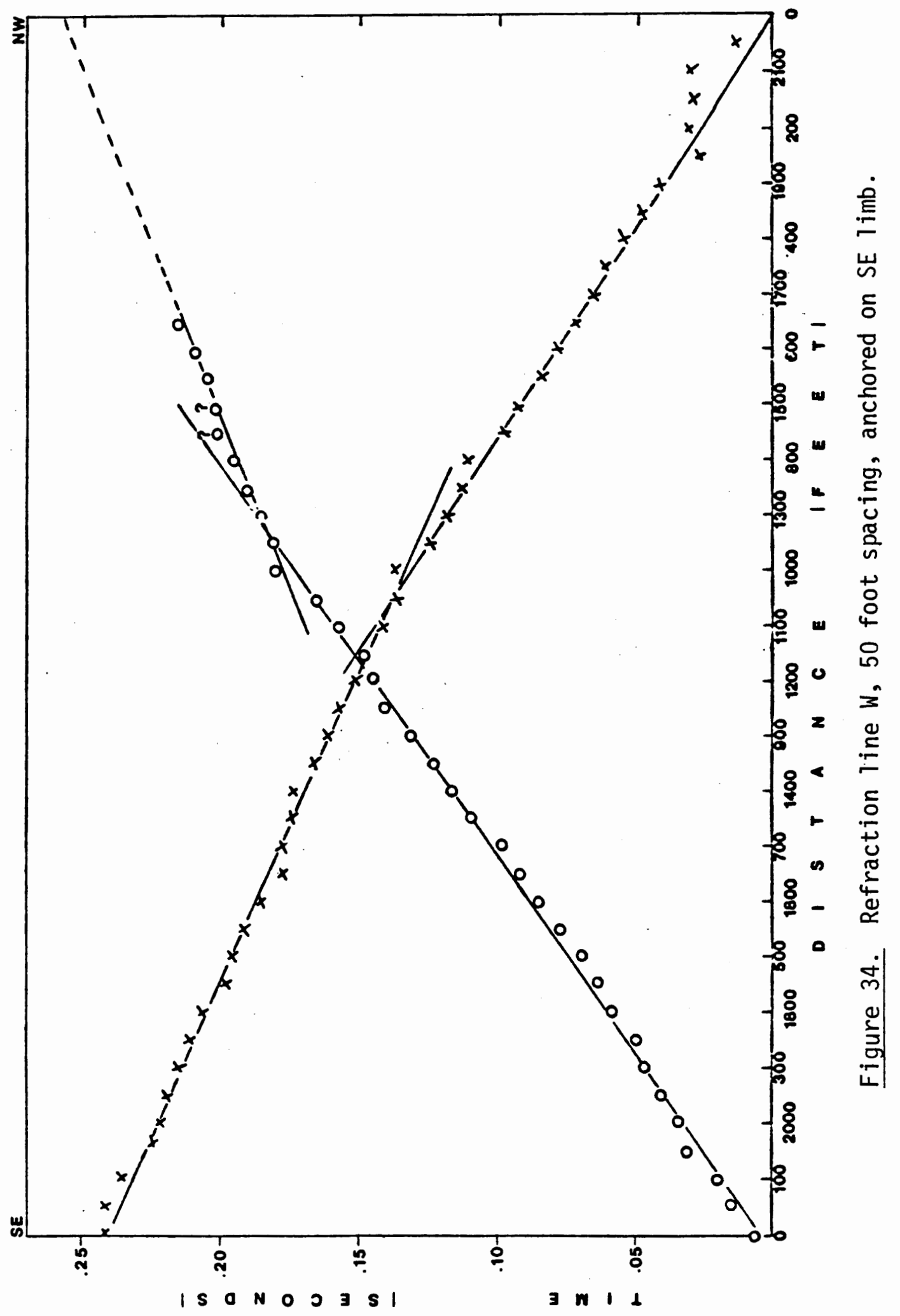




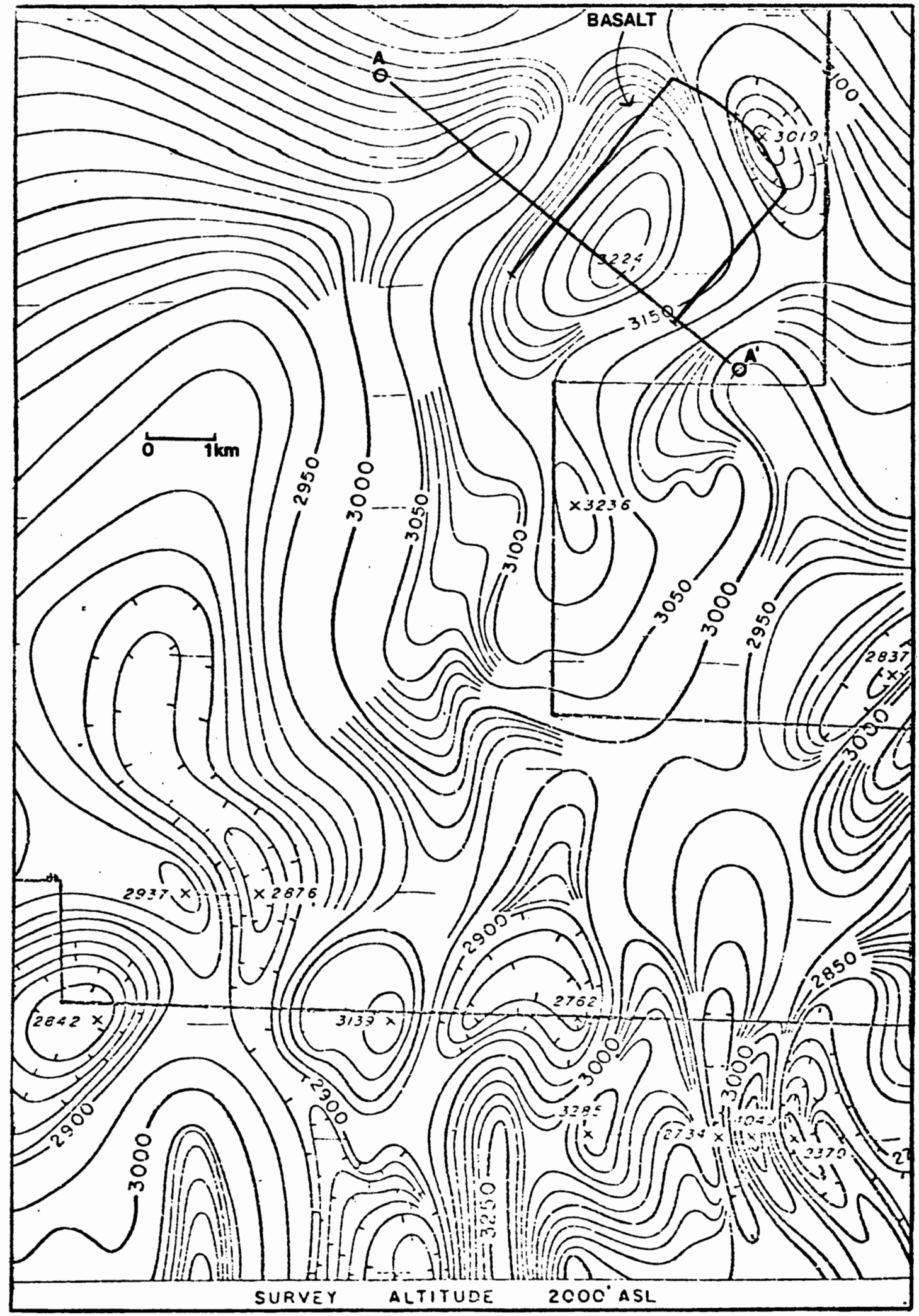

Figure 35. Aeromagnetic anomaly map. (From Tolson, 1976). 


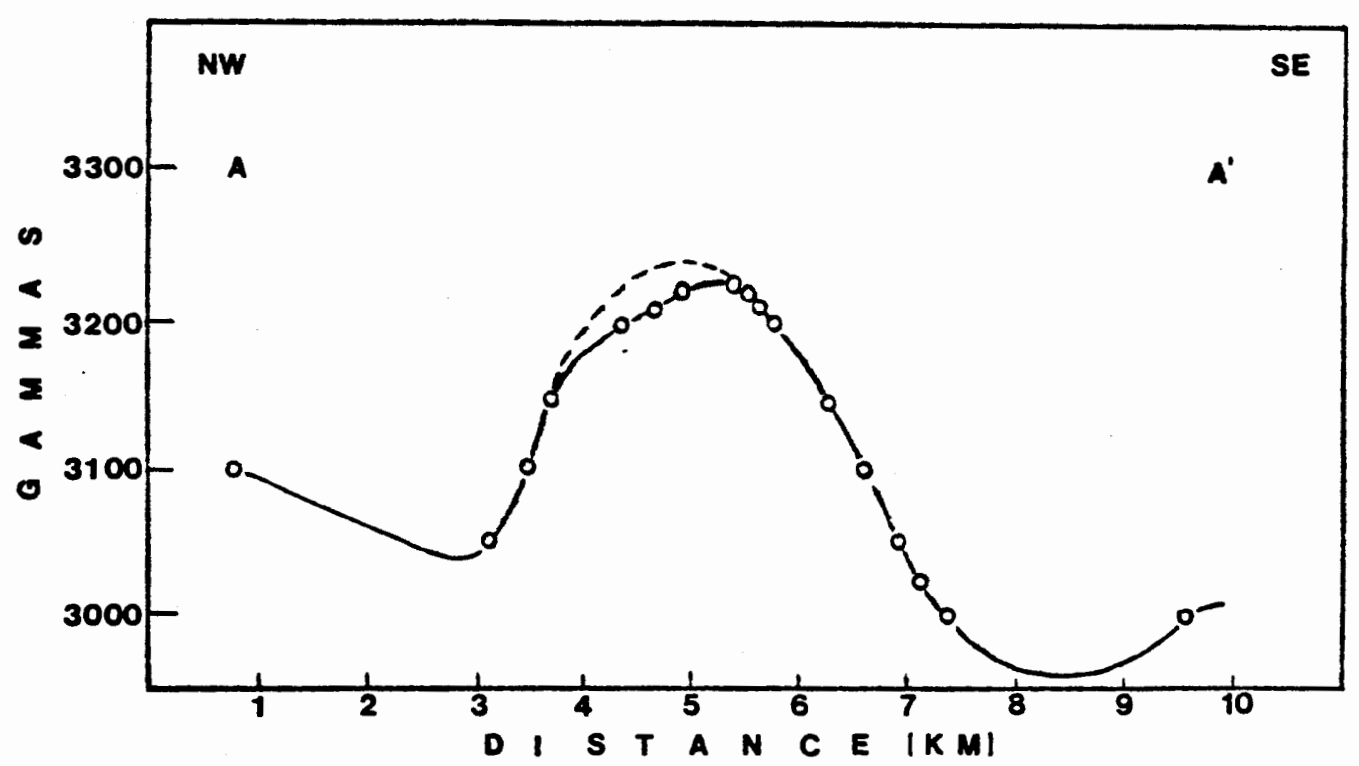

Figure 36. Magnetic profile A-A' from aeromagnetic anomaly map (Figure 35).

ring dikes) is that the plateau ring dikes dip outwardly whereas the Youngs River Falis dikes dip inwardly.

Geophysical surveys thus far have not resolved the Youngs River Falls basalt configuration. Assuming a linear regional gradient, the positive residual anomaly over the $U$ interior must be accounted for by a local model. A slab of basalt underlying the area between the outcropping limbs is one solution, representing a plunging syncline or a ring dike (cone sheet) with a central magma body. The inward dip of all the outcropping dikes supports either hypothesis. The gravity allows either a shallow basalt feature separate from the underlying Tillamook volcanics or a deeper basalt feature adjacent to (and indistinguishable from) the Eocene volcanics. The concept of the central underlying magma body supports a local origin for the basalt whereas a synclinal sheet can be explained either by local origin or by invasion of a lava flow. A hill of denser sedimentary rock encircled by basalt is another solu- 
tion. Such sediments could have been stewed by the hot lava until they became indurated, resistant to erosion and essentially denser. The assumption of a linear gradient may be challenged with aeromagnetic data, in which case the residual anomaly can be attributed to a high on the Eocene volcanics and need not be modelled at all, being no longer residual. The Eocene structural high could have deflected a lava flow around to the northwest along its perimeter. Either of these latter two solutions allows the basalt to be part of an intracanyon flow, possibly the case of an old oxbow and cutoff. Refraction lines anchored on the SE limb curiousiy did not encounter a high speed basalt layer at depth. A major fault mapped on the northwest side of the NW limb is confirmed by regional and local gravity considerations and by the aeromagnetic survey.

Klaskanine River

The northeast-southwest stretch of Highway 202 between Fishhawk Falls and Youngs River Falls crosses an "unnamed ring dike" (Schlicker and others, 1972) (Figure 37). The northeast portion of this ring (stations T26-T33) is cut perpendicularly by the California Barrel Road, along which the $T$ line was conducted. An old railroad grade runs along the same trend as the California Barrel Road and approximately normal to the southwest part of the ring; the M line lies along this grade. Together, these two lines constitute a $4.74 \mathrm{~km}$ traverse across the ring dike feature. The basalt of both ring segments is low Mg (normal) Depoe Bay, and the two crescents appear to have the same lithology. About $.5 \mathrm{~km}$ southwest of the southwest ring segment are two small outcrops of abundantly phyric (normal) Cape Foulweather Basalt (M25-M32). 


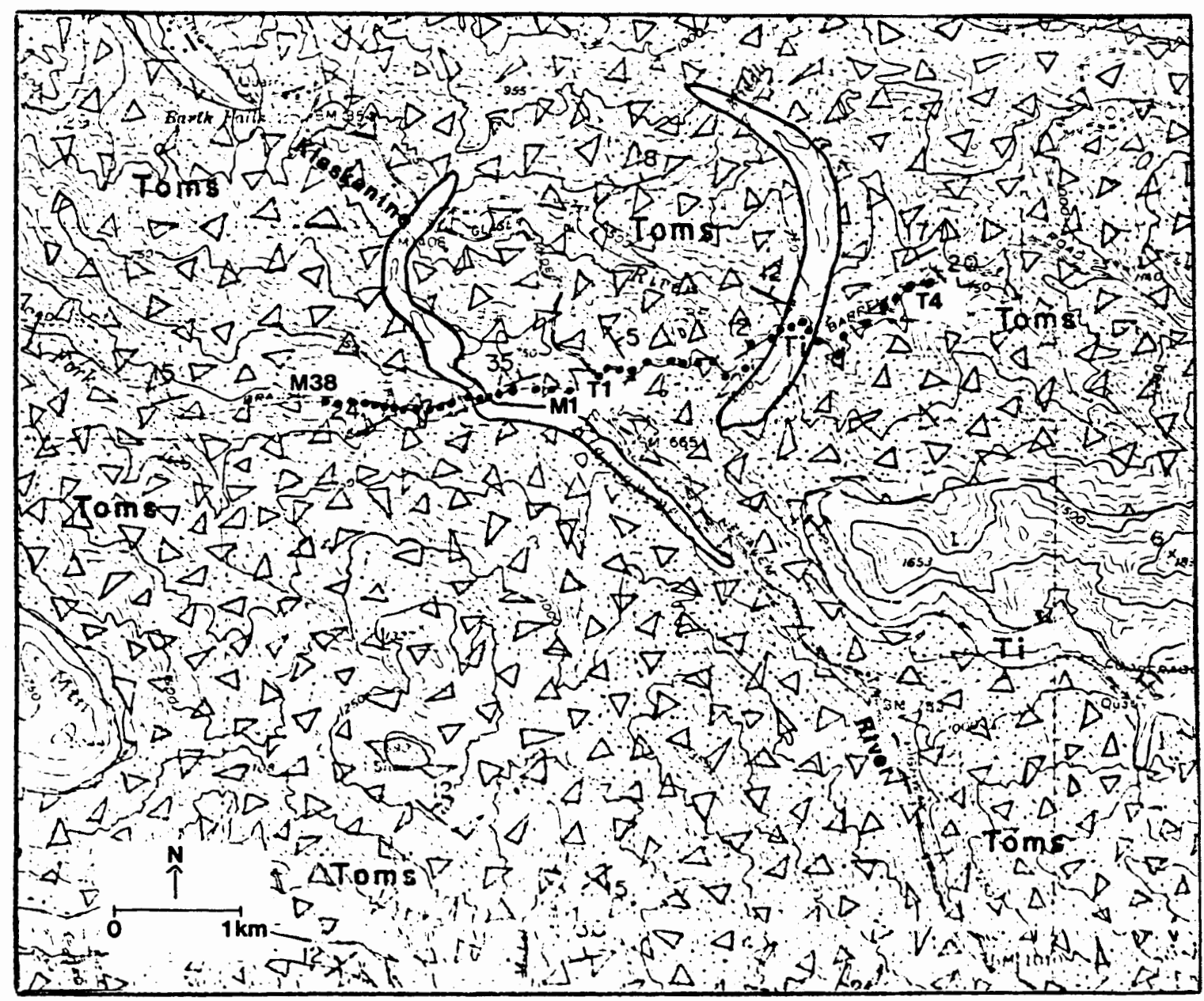

Figure 37. Gravity traverses across dike on the South Fork of the KTaskanine River, T-M line. (Geologic base map from Schlicker and others, 1972).

The best fit projected straight line through the stations and perpendicular to the basalt outcrops is N80E. Although the M line follows the South Fork of the Klaskanine River, the T line does not intersect the River until its easternmost station, T4. Elevation generally decreases from northeast to southwest, and relief is usually greater in directions perpendicular to the traverse. The terrain correction varied on the M line from 1.16 to $1.76 \mathrm{mgals}$; the $T$ line range was 1 arger, .80 to $2.04 \mathrm{mga} / \mathrm{s}$. Adjustments for rock type were no greater than .03 mgal on any station. These terrain correction adjustments were estimated 
from those made for the $J$ line as the basalt dikes are near each other and somewhat similar in extent and shape. Dodds (1963) mapped the basalts wholly within the Astoria Formation, shown as 01igocene-Miocene marine sedimentary rock on Schlicker and others' 1972 map.

Gravity measurements along the $T$ section of the line were made independently of those at the M stations. The $T$ line was surveyed with a transit, but the $M$ line station intervals were reconstructed from previously recorded pacing and station elevations were interpolated from a 20 foot contour interval map. The error associated with the M line will then be slightly greater than that for the $T$ line.

The regional upper crustal model for the T-M line runs N80E for $200 \mathrm{~km}$ with the coast at the midpoint; $\mathrm{km} 0$ is to the northeast in Washington and km 200 is offshore. Geologic controls offshore are provided by two exploratory wells (Snavely and others, 1977) on the continental shelf, wells P-075 and P-072 (Figure 18). Onshore control is provided by the previously designed N51W upper crustal section, which intersects the N80E line on the P 1 ine at Youngs River Falls. In the Nehalem basin, the Clark and Wilson No. 1 and Clatskanie No. 1 (Newton and Van Atta, 1976) delineate the units used in the model. Bathymetry is approximated from the Juan de Fuca Relief map (Price, 1977).

The subsurface between control points was adjusted as for the $J$ line. Again, the underlying Eocene basalt (Tillamook volcanics) had the most influence on the calculated model. The small saddle in CBA gradients immediately northeast of the $T$ line on the state map (Figure 15) is attributed to an irregularity in the Eocene basalts which is sliced by the line of section, or perhaps to a gap at the Tillamook volcanics/ 
Goble volcanics contact (?).

The T-M line lies on the slope of a 13 mgals by $24 \mathrm{~km} \mathrm{Tillamook}$ High extension; this published regional increase from T4 to M38 (northeast to southwest) is reflected in the observed CBA, which increases from T4 to M38 over the length of the line. The upper crustal model generates CBA values that match the observed CBA trend very closely except at the east end, where the calculated values decrease and the observed level off. As there are no control points available for this area, a gradient $(3.09565 \mathrm{mgals} / \mathrm{km})$ was chosen to level the calculated values on this easternmost $.5 \mathrm{~km}$ of the gravity line.

Figure 38 presents the calculated vs. observed CBA gravity. The easternmost kilometer is level, but the gravity values increase steadily by a total of $3 \mathrm{mgals}$ over the remaining $3.5 \mathrm{~km}$. Notable are an $875 \mathrm{~m}$ by $.8 \mathrm{mgal}$ high from T21 to T48, a $350 \mathrm{~m}$ by $-.8 \mathrm{mgal}$ low centered on M16-M17, and a smal1 .4 mgal by $100 \mathrm{~m}$ high at M28.

Despite the different methods of locating the $M$ and $T$ stations, and the lack of cross-checked readings between them, Figure 38 shows that the southwest end of the $T$ line differs from the northeast end of the $M$ line by only $.1 \mathrm{mgal}$, indicating that estimations made for locating the $M$ stations were good and that absolute gravity between lines was maintained. No regional relationship between CBA and topography is apparent.

The residual anomalies on the observed CBA also occur on the observed FAA, although the dimensions have changed (Figure 39). The FAA corresponds more closely with the topography, as both increase from southwest to T42 and then decline to T4 on the northeast end. The broad eastern gravity high on the CBA retains that $850 \mathrm{~m}$ width on the FAA, but 
uI

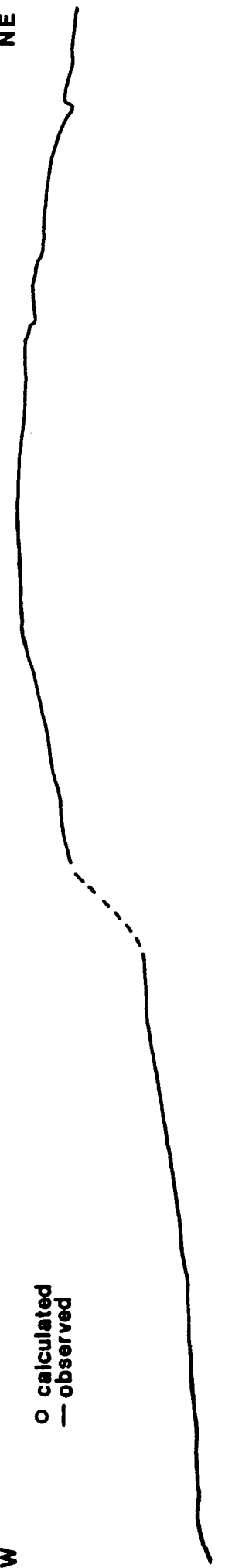

$\infty$

ภำ

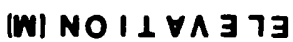

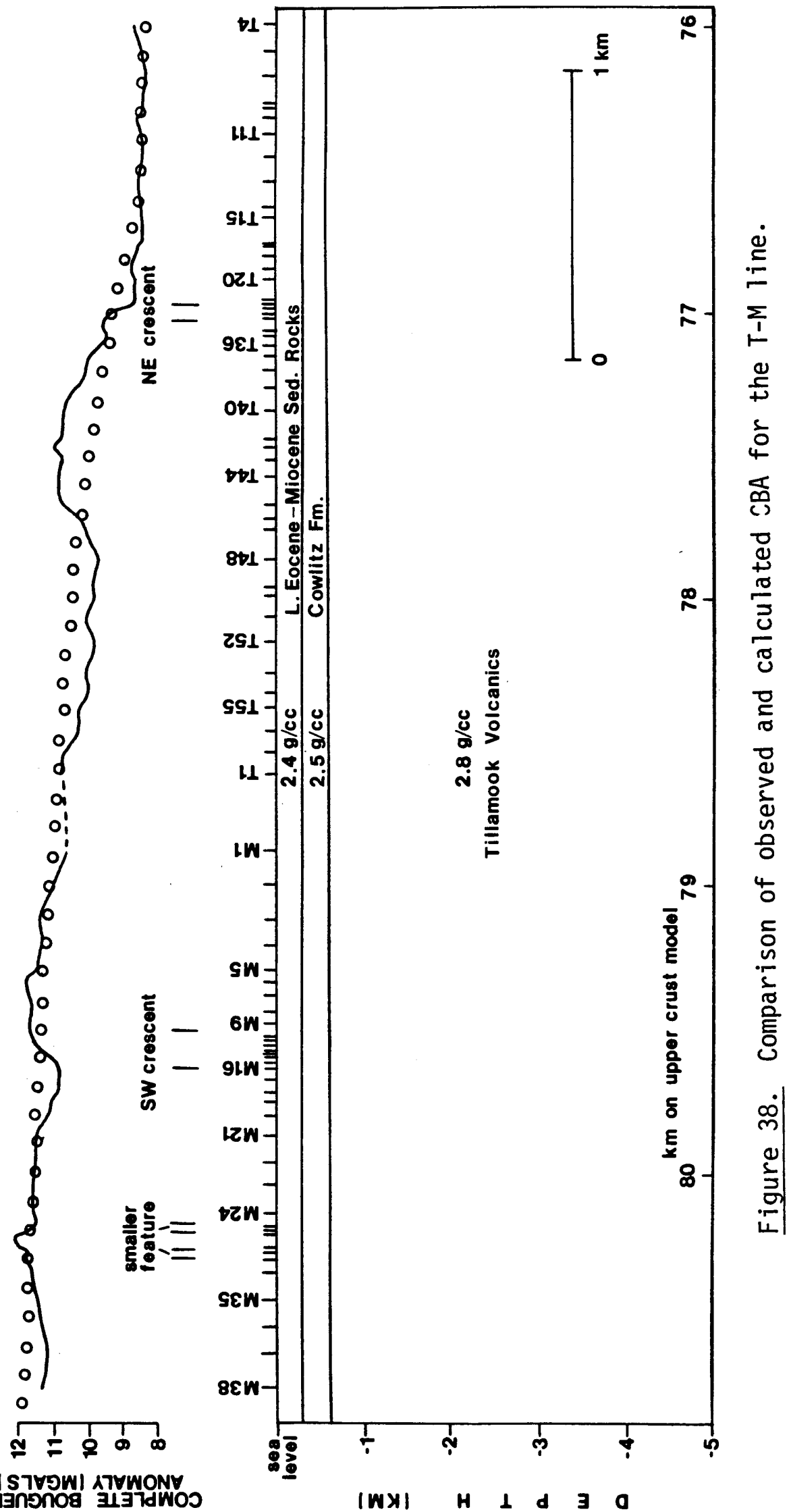


픈

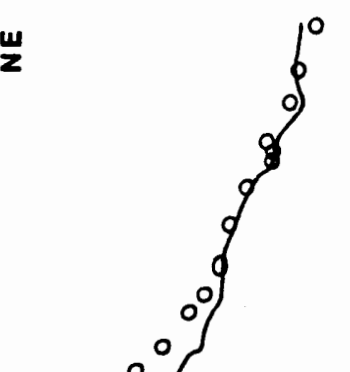

t1-
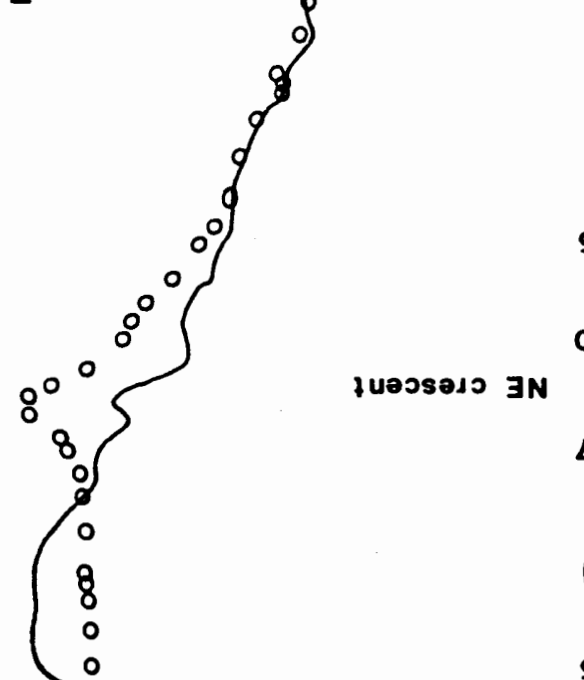

홍

01

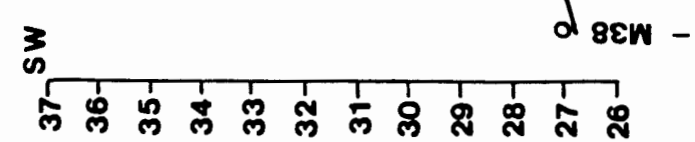

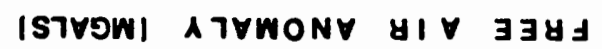

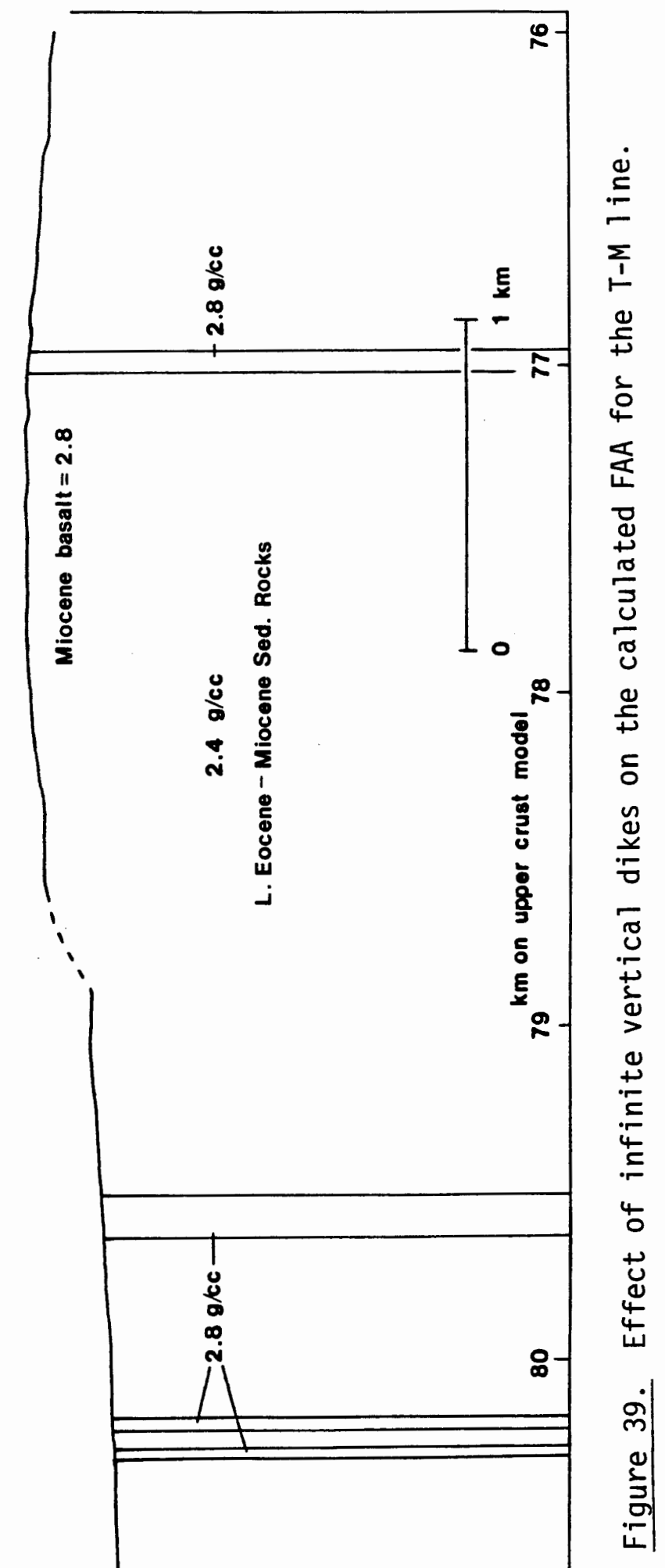


the magnitude of the anomaly has doubled to 1.6 mgals. The gravity low maintains approximately the same magnitude but is superimposed on a sloping gradient so it appears asymmetrical. Only the small western anomaly is reproduced from the CBA identically on the FAA. Its wavelength, magnitude, and correspondence with known outcrop of Cape Foulweather Basalt indicate that the source for this anomaly is above sea level and was not sufficiently corrected for by the Bouguer correction. The gravity low has no corresponding anomalous rock outcrop or lack of material at the surface, but the consistency of its magnitude and relatively short wavelength suggest a near surface source. The occurrence of the broad high on the CBA but halved from its magnitude on the FAA indicates that the Bouguer correction at $2.67 \mathrm{~g} / \mathrm{cc}$ has only partially compensated for it. The sharp increase in both CBA and FAA values from T26 to T33 at the known outcrop of basalt suggest a surficial feature there; the wavelength and magnitude of the broad residual anomaly suggest a source on the order of $250 \mathrm{~m}$ below the surface. Accordingly, focus was switched to the FAA: The regional FAA model was constructed upon the regional upper crustal model in the manner described for the N5IW regional model. The range of adjustment for offline terrain was .88 to 1.46 mgals on the M line and .60 to 1.65 mgals on the $T$ line. The absolute observed FAA matches the published state map values closely except at $\mathrm{T} 4$, where no state control points are available. The $T$ line data suggest that the published +40 and +50 mgals contours should be slightly east of their present locations (Figure 16). Over the length of the gravity line, the FAA regional model, with the CBA gradient at the far east end adjusted for a $2.4 \mathrm{~g} / \mathrm{cc}$ density, nearly produces the 
observed FAA. A gradient of $.33 \mathrm{mgal} / \mathrm{km}$ is needed over the whole length of the modelled line to swing it into agreement with the observed; the westernmost $750 \mathrm{~m}$ of line required a slightly steeper gradient of .8123 $\mathrm{mgal} / \mathrm{km}$. These trends, which may be considered regional with respect to the gravity line, are attributed to the Eocene volcanic irregularity.

Figure 39 illustrates the effect of vertical dikes extending to infinity, here to the Eocene volcanic basement; this model does not fit the observed data.

The smal1 positive residual anomaly on the far southwest, a minor interruption on the steady regional gradient, is an isolated feature associated with the Cape Foulweather basalt. It is most simply modelled as a thick-stemmed funnel (Figure 40). Only $36.77 \mathrm{~m}$ apart, the two 1ithologically and chemically identical outcrops produce one anomaly and are modelled as the same feature. From the $116 \mathrm{~m}$ outcrop width, the basalt narrows symmetrically to $30 \mathrm{~m}$ wide approximately $30 \mathrm{~m}$ below the surface; this width is maintained for an additional $70 \mathrm{~m}$ until the basalt terminates $50 \mathrm{~m}$ above sea level. The triangular near-surface configuration provides the basic shape of the anomaly while the extra depth provides necessary amplitude without expanding the anomaly width.

Both segments of the ring dike are associated on the FAA with steep gravity gradients. Stations T26-T33 are on the east edge of the broad gravity high rising to the west; M9-1/2-M16 are on the west side of a gravity high increasing to the east (or the east edge of the sharper gravity low decreasing to the west). These two gravity highs appear to be separate features as there is no residual anomaly between them from $\mathrm{km} 78$ to $\mathrm{km} 79$. 

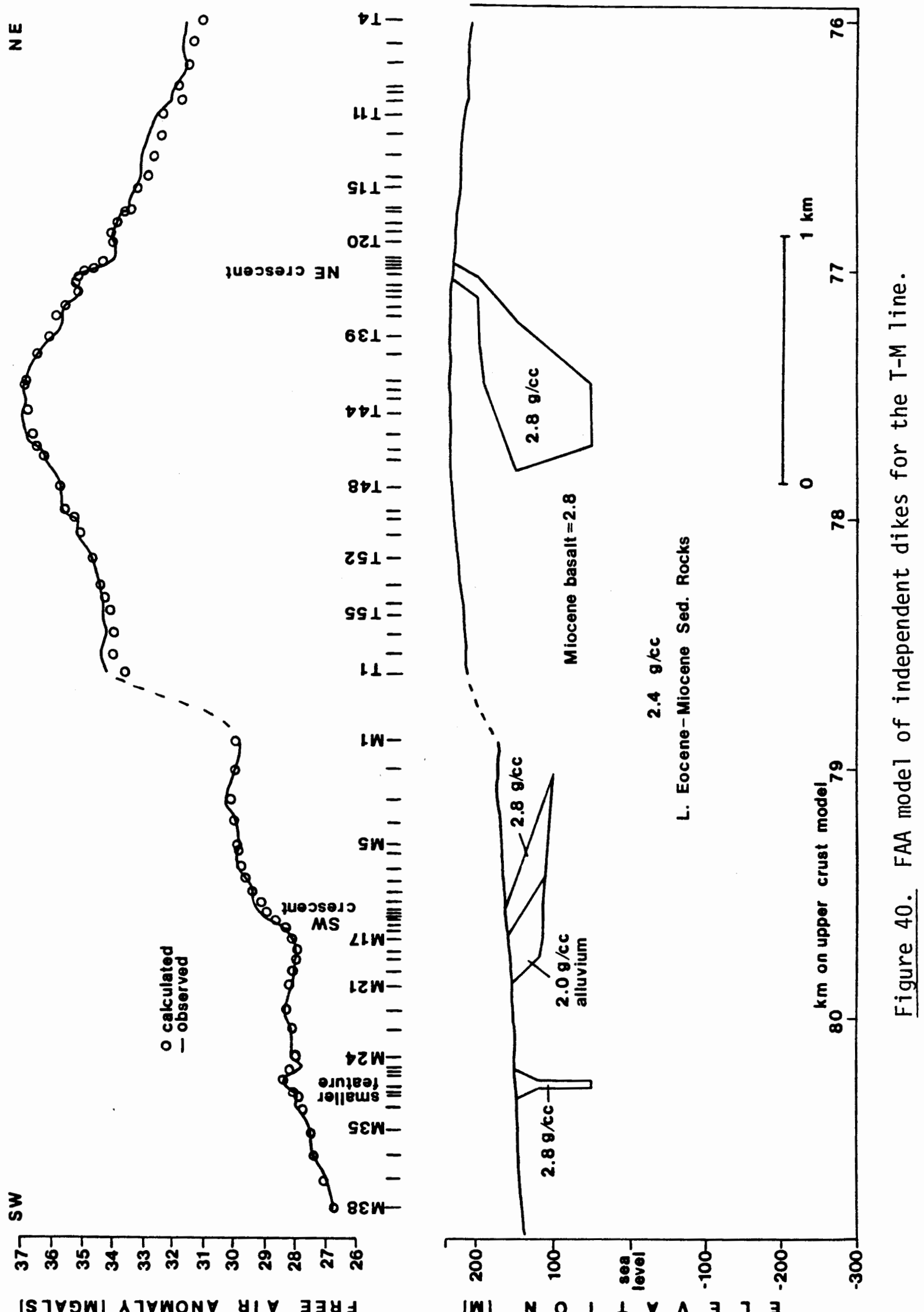

IS TVOWI ATYWON

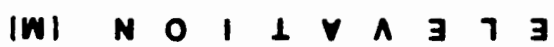


The residual low on the immediate west side of the southwest basalt outcrop has no obvious field manifestations. Its narrow width of roughly $207 \mathrm{~m}$ indicates a local source; an old stream valley filled with alluvium is a possibility. Since the positive basalt anomaly is actually superimposed on the east side of the low, modelling of either feature must take both into account. One solution is illustrated in Figure 40 . The low, modelled as a $207 \mathrm{~m}$ wide block dipping $19^{\circ} \mathrm{E}$ on the west side and $10^{\circ} \mathrm{E}$ on the east side, widening to about $275 \mathrm{~m}$ along an irregular base roughiy $40 \mathrm{~m}$ below the surface, is assigned a density of $2.0 \mathrm{~g} / \mathrm{cc}$ typical for alluvium (Telford and others, 1976). Paralleling this low density block is a similar one of $2.8 \mathrm{~g} / \mathrm{cc}$ density to simulate the basalt. This block crops out for $138.3 \mathrm{~m}$ and dips $10^{\circ} \mathrm{E}$ on the west side to $7^{\circ} \mathrm{E}$ on the east side, widening to approximately $300 \mathrm{~m}$; the lower contact dips $1.5^{\circ} \mathrm{E}$, reaching $100 \mathrm{~m}$ above sea level at its lowest point, $100 \mathrm{~m}$ below the surface. Producing the residual positive anomaly between $\mathrm{km}$ 79.0-79.4 from a basalt outcrop occurring between $\mathrm{km} 79.5-79.6$ on a steep slope that decreases from $\mathrm{km}$ 79.4-79.75 seemed impossible without adjoining the two anomalous blocks. This allowed the effect of the low density alluvium to overcome that of the high density basalt to produce a sharp drop in values under the outcrop and to the west. The parallel arrangement of basalt and alluvium suggests an association of basalt and stream valleys or unconsolidated material.

The broad gravity high on the east end of the line corresponds in extent with a topographic high. The basalt outcrop occurs on the east slope of the high and appears to form a smal1 .4-.6 mgal by $125 \mathrm{~m}$ anomaly upon the larger $1.6 \mathrm{mgals}$ by $850 \mathrm{~m}$ high (Figure 40 ). The model reflects 
this: The main basalt mass underlying the hill ranges from $250 \mathrm{~m}$ wide at $50 \mathrm{~m}$ above sea level to $250 \mathrm{~m}$ wide at $200 \mathrm{~m}$ above sea level; its widest point is $600 \mathrm{~m}$ wide at an elevation of $150 \mathrm{~m}$. The basalt outcrop is a dike dipping $20^{\circ}-23^{\circ} \mathrm{W}$ to approximately $75 \mathrm{~m}$ below the surface at a constant width of $56 \mathrm{~m}$. Its relation to the large basalt body, which must be assumed to be the same rock mass, thus would seem to be as an apophysis.

The two independent dikes model for the ring dike outcrops seems to best fit the FAA because no residual anomaly is observed between the two outcrops from $\mathrm{km} \mathrm{78-79.} \mathrm{However,} 400 \mathrm{~m}(\mathrm{~km} \mathrm{78.6-79.0)}$ of this one kilometer is the gap between the lines where no readings were taken. Consequentiy, the FAA was also modelled for two basalt masses connected at depth. Such a connecting mass as shown in Figure 41 generaliy lessens in thickness from the $T$ mass to the $M$ mass, and is deepest near the middle (under the region of no residual anomaly). A connecting mass wholly above sea level nearly fits the observed data; a deeper and/or thinner slab would improve the match. A 30 m thick slab directly connecting the lower limits of the two previously (Figure 40) modelled dikes (rising from 50-80 m above sea level on the east to 100-130 m above sea level on the west) runs $.5 \mathrm{mgal}$ higher than the observed gravity in the $\mathrm{km} 77.7-79.1$ region; a similar $20 \mathrm{~m}$ thick slab runs $.2-.3$ mgal high. Placing the connecting basalt mass at some depth helps mask its observable gravity effects.

The argument for a hill of denser, possible baked or stewed, sediments creating the broad gravity high that corresponds with the topographic hill is not as strong for this line as it was for the Youngs 
$\mathbf{z}$
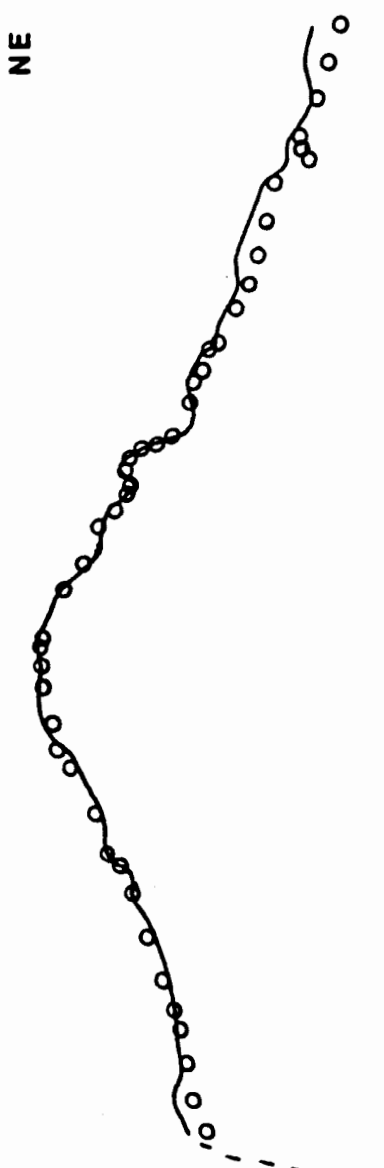

3

๙

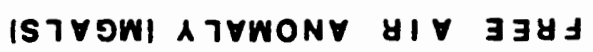
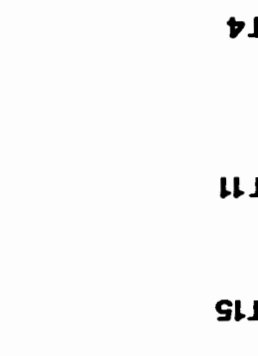

juesseso $\exists \mathrm{N}$ \&E1

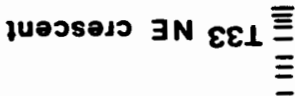

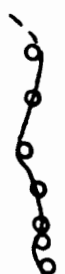

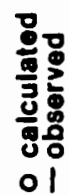
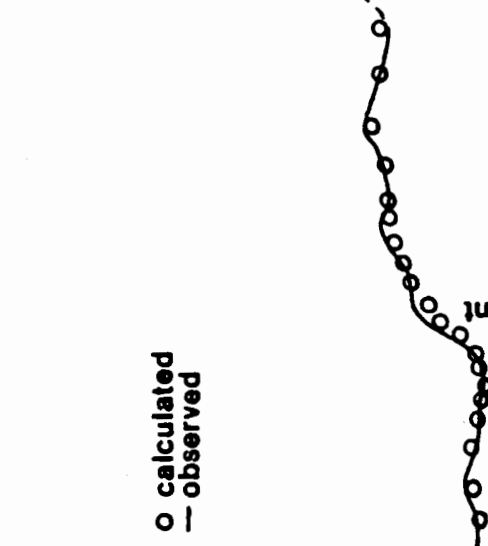

$\oint_{8 \varepsilon w-}$

$\$ 1-$

$6 \varepsilon 1-$

$\equiv$

$\overline{=}$

8b1 -

$=$

S1 -

sst $=$

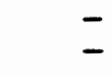

In Bus solpus $\equiv$

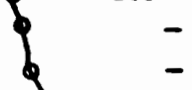


River Falls line. The calculated FAA with uniformly dense $2.4 \mathrm{~g} / \mathrm{cc}$ sediments fits the observed FAA across the hill (including the kilometer between residual anomalies) except between $\mathrm{km} \mathrm{77-78}$ where there is only $6.5 \mathrm{~km}$ of relief, i.e., it is not as dramatic a hill as the one at Youngs River Falls (over $100 \mathrm{~m}$ of relief), where the topography encourages some argument to be made for the resistance of the sediments. Residual positive anomalies and relief are found at the inner contact of both Klaskanine basalt crescents, and it is conceivable that the dikes baked the adjacent sediments to create gravity highs and minor hills. However, this possibility was not modelled or investigated further.

Magnetic data for the Youngs River Falls area suggests that the basalt there encircles a structural high on the underlying Eocene basalt and that this could account for the residual gravity high over the hill. On the basis of the information available for the Klaskanine ring dike, however, the necessity for a subsurface basalt mass such as the one modelled under the hill is difficult to dismiss and, in the absence of evidence to the contrary, a linear gradient must be assumed. The best fit to the observed data is independent dikes, although dikes connected at depth is possible if the added basalt layer is relatively thin and deep. 
Hypotheses advocating local eruptive centers for the Miocene coastal basalts of Oregon and Washington differ fundamentally from those proposing that the basalts are the distal ends of Columbia River basalt plateau flows entering the coastal environment from vents $500 \mathrm{~km}$ to the east. In this study, these alternatives were examined using geochemical and geophysical techniques to investigate the lateral and vertical extents of selected coastal basalts in Clatsop County, Oregon.

Instrumental Neutron Activation Analys is and paleomagnetic measurements of 38 coastal basalt samples allowed their classification into three chemical types that correlate with Columbia River basalt plateau flows mapped in western Oregon: reversed $\left(R_{2}\right)$ and normal $\left(\mathrm{N}_{2}\right)$ low Mg Depoe Bay, high Mg Depoe Bay, and Cape Foulweather coastal basalts correlate respectively with reversed $\left(R_{2}\right)$ and normal $\left(\mathrm{N}_{2}\right)$ low Mg Grande Ronde, high Mg Grande Ronde, and Frenchman Springs plateau basalts. The oldest basalts, reversed and normal low Mg Depoe Bay, occurring from the Wickiup Ridge area northwest to Astoria and from Nicolai Mountain southwest to Elsie and Neahkahnie Mountain, separate the Eocene and plateau basalts to their east from the younger Miocene coastal basalts to their west. Low Mg normal Depoe Bay basalts are found additionally throughout the study area. Known and presumed high Mg Depoe Bay basalts form a broad northeast-southwest band of brecciated peaks extending from the Wickiup Mountain area through Saddle and Humbug Mountains and southwest beyond the study area to peaks such as Onion, 
Sugarloaf, and Angora. They are flanked predominantly by low Mg Depoe Bay flows. Cape Foulweather Basalt is the youngest chemical type found in the study area and perhaps the most varied. At Seal Rocks, to the south of the area, abundantly porphyritic and distinctively reversed flows seem to correlate with the lowermost reversed (excursional) Ginkgo flow of the Frenchman Springs Member. Intrusions forming bands along the South Fork of the Klaskanine River and along Highway 202 are abundantly porphyritic, occasionaliy glomeroporphyritic, and normally polarized, probably equivalent to a younger Ginkgo flow. Normally polarized, sparsely porphyritic intrusions at Youngs River Falls and west of the Lewis and Clark River have high $\mathrm{Cr}$ content and suggest equivalency with the Sand Hollow flow unit of the Frenchman Springs Member.

The basalt units form an areal pattern that lands itself to varied interpretations. The basalt intrusions themselves tend to be irregular in shape, although dikes further inland are commonly more linear while those seaward are more globular. Intrusions are more common inland, joined by extrusive rocks to the west. Sinuous outcrop patterns suggest topographic control, but at one extreme can resemble either ring dikes or cutoff oxbow meanders. Concentrations of flow types in bands, such as brecciated high Mg basalt peaks or abundantly phyric Cape Foulweather Basalt, suggest either a vent system or a stream valley route in a downwarped area. Although patterns based on isolated outcrops offer inconclusive interpretations, they provide clues and inspirations for continuing work in the area; the identification of flows is a fundamental basis for any additional work and adds significantly to the existing 
basalt catalogue.

Gravity lines conducted over coastal basalt features allow tentative subsurface models to be formulated. Linear dikes of Depoe Bay Basalt at Fishhawk Falls (normally polarized) and Denver Point (reversed) are shallow (107 and $45 \mathrm{~m}$ deep, respectively). However, the existence of thin ( $\leq 10 \mathrm{~m}$ wide) feeder dikes underlying the near surface basalt masses cannot be disproved. Two normally polarized Depoe Bay Basalt crescentshaped dikes crop out along the South Fork of the Klaskanine River. Despite plan view resemblance to a ring dike, the two arcuate segments do not appear to be connected at depth. The southwest crescent dips gently $\left(7^{\circ}-10^{\circ}\right)$ northeast and is $100 \mathrm{~m}$ deep. The northeast crescent appears to be an apophysis dipping $20^{\circ}-23^{\circ}$ west to approximately $75 \mathrm{~m}$ below the surface, where a $150 \mathrm{~m}$ thick basalt mass extends as deep as $50 \mathrm{~m}$ above sea level and as wide as $600 \mathrm{~m}$. The U-shaped Sand Hollow Cape Foulweather Basalt dike at Youngs River Falls may be satisfactorily modelled as a shallow (maximum depth $.23 \mathrm{~km}$ below sea level) or deep (minimum depth $.3 \mathrm{~km}$ below sea level) syncline or ring dike. The basalt limbs dip toward each other. Alternatively, the basalt might encircle either a hill of somewhat denser sedimentary rock or a buried Tillamook volcanic high, in which cases the gravity data do not require the limbs of the $U$ to be connected at depth by a basalt slab. Abundantly phyric Cape Foulweather Basalt outcrops encountered along two different qravity traverses are consistently shallow (100 $\mathrm{m}$ or less below the surface).

Although unique and incontrovertible solutions to aravity profiles do not exist, and various models are presented for each coastal basalt feature, some subsurface configurations can be eliminated. In regard 
to coastal basalt origin, perhaps the significance of the gravity data is that they do not eliminate the possibility of a plateau origin for the dikes. The near surface ( $500 \mathrm{~m}$ below sea level) Eocene volcanic basement partially limited the resolution expected for dense basaltic dikes within marine sedimentary rocks, and yet all the dikes can be modelled as shallow. Some, in fact, demand it.

In the mid-Miocene, the study area was a deltaic and estuarine environment of water-saturated sediments, Eocene volcanic topographic highs, and an ocean-continent boundary. Such incompetent host material and an active tectonic setting are well suited to hypotheses either for invasion by Columbia River basalt flows or for local eruption of lavas that result in brecciated, peperitic, and irregular intrusions. A1though the accumulated evidence regarding the coastal basalts is available for either hypothesis, the results of this study would seem to lend credence to the plateau origin for the coastal basalts. All the basalt outcrops are correlative solely with established western Oregon plateau flows. Distribution patterns suggest topographic control by the Eocene highlands and stream valleys. The high Mg basalt breccia at Saddle Mountain overlies the older $10 \mathrm{w}$ Mg Depoe Bay Basalt. Seemingly regional and straight bands of 1 ow Mg Depoe Bay Basalt are found to be composed of both normal and reversed flows. Vertical dikes extending to the gravity basement are not suitable models for any of the features investigated, while shallow near surface basalt masses are either preferred or distinctly possible in all cases.

Future studies might do well to examine closely the basalt-sedimentary rock contacts and to look for (and map) possible basalt routes 
through the Coast Range. If the plateau basalts did invade the coastal area, discovery of their passageways could explain the westernmost basalt occurrences and help synthesize the patterns and accumulated data. It seems likely that a dynamic contact between physically dissimilar units could record directions of movement and indications of the circumstances of intrusion. 


\section{REFERENCES}

Additon, M.K., and Seil, R.0., 1979, Columbia River Basalt reference sample: Richland, Wash., Rockwell International, 25 p.

Anderson, J.L., 1978, The stratigraphy and structure of the Columbia River Basalt in the Clackamas River drainage: Portland, Oreg., Portland State University master's thesis, $136 \mathrm{p}$.

Atlantic Richfield Hanford Co., 1976, Preliminary feasibility study on storage of radioactive wastes in Columbia River Basalts: ERDA Rept. ARH-ST-137, v. 1, 168 p.; v. 2, 264 p.

Baldwin, E.M., 1952, The geology of Saddle Mountain, Clatsop County, Oregon: Geological Society of the Oregon Country Geological News Letter, v. 18, no. 4, p. 29-30.

Beaulieu, J.D., 1973, Environmental geology of inland Tillamook and Clatsop Counties, Oregon: Oregon Department of Geology and Mineral Industries Bulletin 79, $65 \mathrm{p}$.

Beeson, M.H., Bentley, R.D., and Moran, M.R., 1976a, Prel iminary correlation of Lower Yakima basalt flows in western Oregon with the type area in central Washington [abs.]: Geological Society of America Abstracts with Programs, v. 8, no. 3, p. 353-4.

Beeson, M.H., Johnson, A.G., and Moran, M.R., 1976b, Portland environmental geology - fault identification: Menlo Park, Calif., Final technical report (Sept. 1, 1974 to Dec. 31, 1975) to the U.S. Geological Survey, $107 \mathrm{p}$.

Beeson, M.H., and Moran, M.R., 1979, Columbia River Basalt Group stratigraphy in western Oregon: Oregon Geology, v. 41, no. 1, p. 11-14.

Beeson, M.H., Moran, M.R., Anderson, J.L., Timm, Susan, and Vogt, B.F., 1979, Stratigraphy and structure of the Columbia River Basalt Group in the Cascade Range, Oregon in Geothermal resource assessment of Mount Hood: Oregon Department of Geology and Mineral Industries Open-File Report 0-79-8, p. 5-77.

Beeson, M.H., Moran, M.R., and 01son, F.L., 1976, Geochemical data on Columbia River Basalt stratigraphy in western Oregon [abs.]: Geological Society of America Abstracts with Programs, v. 8, no. 3, p. 354 . 
Beeson, M.H., Perttu, Rauno, and Perttu, Janice, 1979b, The origin of the Miocene basalts of coastal Oregon and Washington: an alternative hypothesis: Oregon Geology, v. 41, no. 10, p. 159-166.

Berg, J.W., Jr., and Thiruvathuka 1, J.V., 1967, Free-air gravity anomaly map of Oregon: Oregon Department of Geology and Mineral Industries GMS $4 a$.

--- 1967, Complete Bouguer gravity anomaly map of Oregon: Oregon Department of Geology and Mineral Industries GMS $4 \mathrm{~b}$.

Bonini, W.E., Hughes, D.W., and Danes, Z.F., 1974, Complete Bouguer gravity anomaly map of Washington: State of Washington Department of Natural Resources, Division of Geol. and Earth Resources GM-11.

Bromery, R.W., and Snave1y, P.D., Jr., 1964, Geologic interpretation of reconnaissance gravity and aeromagnetic surveys in northwestern Oregon: U.S. Geological Survey Bulletin 1181-N, 13 p.

Byerly, Gary, and Swanson, Don, 1978, Invasive Columbia River basalt flows along the northwestern margin of the Columbia Plateau, northcentral Washington [abs.]: Geological Society of America Abstracts with Programs, v. 10, no. 3, p. 98.

Choiniere, S.R., and Swanson, D.A., 1979, Magnetostratigraphy and correlation of Miocene basalts of the northern Oregon coast and Columbia Plateau, southeast Washington: American Journal of Science, v. 279 , p. $755-777$.

Choiniere, S.R., Swanson, D.A., Simpson, Robert, and Watkins, N.D., 1976, Stratigraphic resolution of ambiguities in the interpretation of unusual paleomagnetic directions in Miocene basalts of the Oregon coast: EOS, Transactions of the American Geophysical Union, v. 57, no. 4 , p. 237.

Couch, Richard, and Braman, David, 1979, Geology of the continental margin near Florence, Oregon: Oregon Geology, v. 41, no. 11, p. $171-179$.

Dehl inger, Peter, Couch, R.W., McManus, D.A., and Gemperle, Michael, 1970, Northeast Pacific structure in Maxwe11, A.E., ed., The sea: New York, Wiley-Interscience, vol. 4 , part II, p. 133-189.

Dehlinger, Peter, Rinehart, R.W., Couch, R.W., and Gemperle, Michael, 1967, Free-air gravity anomaly map west of Oregon: Oregon Department of Geology and Mineral Industries GMS $4 \mathrm{c}$.

Dobrin, M.B., 1976, Introduction to geophysical prospecting, 3rd ed.: New York, McGraw-Hill, Inc., 630 p. 
Dodds, R.K., 1963, Geology of the western half of the Svensen quadrangle, Oregon: Eugene, Oreg., University of Oregon master's thesis, $110 \mathrm{p}$.

--- 1970, The age of the "Columbia River Basalts" near Astoria, Oregon, in Gilmour, E.H., and Stradling, D., eds., Proceedings of the Second Columbia River Basalt Symposium: Cheney, Wash., Eastern Washington State College Press, p. 239-69.

Flanagan, F.J., 1973, 1972 values for international geochemical reference samples: Geochimica et Cosmochimica Acta, v. 37, p. 1189-1200.

Hi11, D.W., 1975, Chemical composition of Oregon and Washington coastal basalts: Corvallis, Oreg., Oregon State University master's thesis, $99 \mathrm{p}$.

Hodges, C.A., 1978, Basaltic ring structures of the Columbia Plateau: Geological Society of America Bulletin, v. 89, no. 9, p. 1281-1289.

Holmgren, D.A., 1970, K/Ar dates and paleomagnetics of the type Yakima Basalt, central Washington, in Gilmour, E.H., and Stradling, D., eds., Proceedings of the Second Columbia River Basalt Symposium: Cheney, Wash., Eastern Washington State College Press, p. 189-199.

Hooper, P.R., Knowles, C.R., and Watkins, N.D., 1979, Magnetostratigraphy of the Imnaha and Grande Ronde basalts in the southeast part of the Columbia Plateau: American Journal of Science, v. 279, p. 737-754.

Jones, T.D., 1977, Analys is of a gravity traverse south of Portland, Oregon: Portland, Oreg., Portland State Iniversity bachelor's thesis, $54 \mathrm{p}$.

Kienle, C.F., Jr., 1971, The Yakima Basalt in western Oregon and Washington: Santa Barbara, Calif., University of California at Santa Barbara doctoral dissertation, $171 \mathrm{p}$.

Kulm, L.D., and Fowler, G.A., 1974, Oregon continental margin structure and stratigraphy: a test of the imbricate thrust model, in Burk, C.A., and Drake, C.L., eds., The geology of continental margins: New York, Springer-Verlag, p. 261-283.

Layfield, R.A., 1936, Geology of Saddle Mountain State Park and vicinity: Geological Society of the Oregon Country Geological News Letter, v. 2 , no. 24, p. 4-12.

Lefebvre, R.H., 1970, Columbia River Basalts of the Grand Coulee Area, in Gilmour, E.H., and Stradling, D., eds., Proceedings of the Second Columbia River Basalt Symposium: Cheney, Wash., Eastern Washington State Collede Press, p. 1-38. 
Lowry, W.D., and Baldwin, E.M., 1952, Late Cenozoic geology of the lower Columbia River valley, Oregon and Washington: Geological Society of America Bulletin, v. 63, p. 1-24.

MacLeod, N.S., and Snavely, P.D., Jr., 1973, Volcanics and intrusive rocks of the central part of the Oregon Coast Range, in aeologic field trips in northern Oregon and southern Washington: Oregon Department of Geology and Mineral Industries Bulletin 77, p. 47-74.

McDougal 1, Ian, 1976, Geochemistry and origin of basalt of the Columbia River Group, Oregon and Washington: Geological Society of America Bulletin, v. 87, no. 5, p. 777-792.

McKee, Bates, and Stradling, Dale, 1970, The sag flowout: a newly described volcanic structure: Geological Society of America Bulletin, v. 81, p. 2035-2044.

McKee, E.H., Swanson, D.A., and Wright, T.L., 1977, Duration and volume of Columbia River Basalt volcanism, Washington, Oregon, and Idaho [abs.]: Geological Society of America Abstracts with Programs, v. 9 , no. 4 , p. $463-4$.

Murphy, Thomas, and Niem, A.R., 1980, Age, facies relations, and a river mouth/shelf/submarine channel depositional model for the Clifton Formation, northwestern Oregon [abs.]: Geological Society of America Cordilleran Section Abstracts with Programs, v. 12, no. 3, p. 144 .

Nathan, Simon, and Fruchter, J.S., 1974, Geochemical and paleomagnetic stratigraphy of the Picture Gorge and Yakima Basalts (Columbia River Group) in central Oregon: Geological Society of America Bulletin, v. 85, no. 1, p. 63-76.

Nelson, M.P., 1977, Tertiary stratigraphy and sedimentation in the Lewis and Clark River - Youngs River Area, Clatsop County, northwestern Oregon: Corvallis, Oreg., Oregon State University master's thesis, 242 p.

Newton, V.C., 1969, Subsurface geology of the lower Columbia and Willamette basins, Oregon: Oregon Department of Geology and Mineral Industries $0 i 1$ and Gas Investigations No. 2, $121 \mathrm{p}$.

Newton, V.C., and Van Atta, R.0., 1976, Prospects for natural gas production and underground storage of pipe-line gas in the Upper Nehalem River basin, Columbia-Clatsop Counties, Oregon: Oregon Department of Geology and Mineral Industries $0 i 1$ and Gas Investigations No. $5,56 \mathrm{p}$

Niem, A.R., 1974, Formation of large-scale penecontemporaneous folds and intraformational breccias in the Astoria Formation, northwestern Oregon [abs.]: Geological Society of America Abstracts with Programs, v. 6 , no. 3, p. 229. 
Niem, A.R., and Cressy, F.B., Jr., 1973, K-Ar dates for sills from the Neahkahnie Mountain and Tillamook Head areas of the northwestern Oregon coast: Isochron/West, no. 7, p. 13-15.

Niem, A.R., and Van Atta, R.0., 1973, Cenozoic stratigraphy of northwestern Oregon and adjacent southwestern Washington, in jeologic field trips in northern Oregon and southern Washington: Oregon Department of Geology and Mineral Industries Bulletin 77, p. $75-132$.

Norman, E.S., 1980, Geology of the Columbia River Basalt in Silver Falls State Park, Oregon: Portland, Oreg., Portland State University bachelor's thesis, $31 \mathrm{p}$.

Osawa, Masumi, and Goles, G.G., 1970, Trace element abundances in Columbia River Basalts, in Gilmour, E.H., and Stradling, D., eds., Proceedings of the Second Columbia River Basalt Symposium: Cheney, Wash., Eastern Washington State College Press, p. 55-71.

Parks, Harold, and Banami, A.M., 1971, Gravity survey of Columbia Plateau ring dikes [abs.]: EOS, Transactions of the American Geophysical Union, v. 52, no. 5, p. 433.

Penoyer, P.E., 1977, Geology of the Saddle and Humbug Mountains area, Clatsop County, northwestern Oregon: Corvallis, Oreg., Oregon State University master's thesis, $249 \mathrm{p}$.

Price, W.R., 1977, Juan de Fuca plate study map: relief: Pacific Geoscience Centre, Earth Physics Branch, Sidney, B.C., Canada.

Schlicker, H.G., Deacon, R.T., Beaulieu, J.D., and 01cott, G.W., 1972, Environmental geology of the coastal region of Tillamook and Clatsop Counties, Oregon: Oregon Department of Geology and Mineral Industries Bulletin 74, $138 \mathrm{p}$.

Schlicker, H.G., Deacon, R.J., 01cott, G.W., and Beaulieu, J.D., 1973, Environmental geology of Lincoln County, Oregon: Oregon Department of Geology and Mineral Industries Bulletin 81, $171 \mathrm{p}$.

Schmincke, Hans-U1rich, 1964, Petrology, paleocurrents, and stratigraphy of the Ellensburg Formation and interbedded Yakima basalt flows, south-central Washington: Baltimore, Md., Johns Hopkins University doctoral dissertation.

--- 1967, Fused tuff and peperites in south-central Washington: Geological Society of America Bulletin, v. 78, no. 3, p. 319-330.

Seely, D.R., Vail, P.R., and Walton, G.G., 1974, Trench slope model, in Burk, C.A., and Drake, C.L., eds., The geology of continental margins: New York, Springer-Verlag, p. 249-260. 
Shaw, H.R., and Swanson, D.A., 1970, Eruption and flow rates of flood basalts, in Gilmour, E.H., and Stradling, D., eds., Proceedings of the Second Columbia River Basalt Symposium: Cheney, Wash., Eastern Washington State College Press, p. 271-299.

--- 1970, Speculations on the fluid mechanical history of Yakima basalt flows [abs.], in Gilmour, E.H., and Stradling, D., eds., Proceedings of the Second Columbia River Basalt Symposium: Cheney, Wash., Eastern Washington State College Press, p. 330.

Silver, E.A., 1972, Pleistocene tectonic accretion of the continental slope off Washington: Marine Geology, v. 13, p. 239-249.

Simpson, R.W., and Cox, Allan, 1977, Paleomagnetic evidence for tectonic rotation of the Oregon Coast Range: Geology, v. 5, no. 10, p. 585-589.

Snavely, P.D., Jr., MacLeod, N.S., and Wagner, H.C., 1973, Miocene tholeiitic basalts of coastal Oregon and Washington and their relations to coeval basalts of the Columbia Plateau: Geological Society of America Bulletin, v. 84, no. 2, p. 387-424.

Snavely, P.D., Jr., MacLeod, N.S., Wagner, H.C., and Lander, D.L., 1980a, Geology of the west-central part of the Oregon Coast Range, in Geological field trips in western Oregon and southwestern Washington: Oregon Department of Geology and Mineral Industries Bulletin 101, p. 39-76.

Snavely, P.D., Jr., Pearl, J.E., and Lander, D.L., 1977, Interim report on petroleum resources potential and geologic hazards in the outer continental shelf-Oregon and Washington Tertiary province: U.S. Geological Survey Open-File Report 77-282, 64 p.

Snavely, P.D., Jr., and Wagner, H.C., 1963, Tertiary geologic history of western Oregon and Washington: Washington Division of Mines and Geology Report of Investigations 22, $25 \mathrm{p}$.

--- 1964, Geologic sketch of northwestern Oregon: U.S. Geological Survey Bul1etin 1181-M, $17 \mathrm{p}$.

Snavely, P.D., Jr., Wagner, H.C., and Lander, D.L., 1980b, Interpretation of the Cenozoic geologic history, central Oregon continental margin: cross-section summary: Geological Society of America Bulletin Part I, v. 91, p. 143-6.

Swanson, D.A., 1967, Yakima Basalt of the Tieton River area, southcentral Washington: Geological Society of America Bulletin, v. 78, p. 1077-1110. 
Swanson, D.A., and Wright, T.L., 1976, Guide to field trip between Lewiston, Idaho and Picture Gorge, Oreqon, emphasizing the Columbia River Basalt Group, 56 p., draft for Geological Society of America Cordilleran Section Field Guide No. 1.

--- 1978, Some important facts and inferences concerning the Columbia River Basalt Group, in Tectonics and Seismicity of the Columbia Plateau Workshop, Battelle Waste Isolation Program: Richland, Wash., Rockwell Hanford Operations, $10 \mathrm{p}$.

Swanson, D.A., Wright, T.L., and Helz, R.T., 1975, Linear vent systems and estimated rates of magma production and eruption for the Yakima Basalt on the Columbia Plateau: American Journal of Science, v. 275, p. 877-905.

Swanson, D.A., Wright, T.L., Hooper, P.R., and Bentley, R.D., 1979, Revisions in stratigraphic nomenclature of the Columbia River Basalt Group: U.S. Geological Survey Bulletin 1457-G, 59 p.

Tatsumoto, M., and Snavely, P.D., Jr., 1969, Isotopic composition of lead in rocks of the Coast Range, Oregon and Washington: Journal of Geophysical Research, v. 74, p. 1087-1100.

Taubeneck, W.H., 1970, Dikes of Columbia River Basalt in northeastern Oregon, western Idaho, and southeastern Washington, in Gilmour, E.H., and Stradling, D., eds., Proceedings of the Second Columbia River Basalt Symposium: Cheney, Wash., Eastern Washington State College Press, p. 73-96.

Telford, W.M., Geldart, L.P., Sheriff, R.E., and Keys, D.A., 1976, Applied geophysics: New York, Cambridge University Press, 860 p.

Texas Instruments, Inc., 1963, Worden gravity meter operating manual n. 81537-5: Houston, Texas, Texas Instruments, Inc., 89 p.

Thiruvathukal, J.V., Berg, J.W., Jr., and Heinrichs, D.F., 1970, Regional gravity of Oregon: Geological Society of America Bulletin, v. 81, p. 725-738.

Tolson, P.M., 1976, Geology of the Seaside-Youngs River Fal is area, Clatsop County, Oregon: Corvallis, Oreg., Oregon State University master's thesis, $191 \mathrm{p}$.

Warren, W.C., Norbisrath, Hans, and Grivetti, R.M., 1945, Geology of northwest Oreqon west of the Willamette River and north of latitude $45^{\circ} 15^{\prime}$ : U.S. Geological Survey $0 i 1$ and Gas Investigations Preliminary Map 42.

Waters, A.C., 1961, Stratigraphic and lithologic variations in the Columbia River Basalt: American Journal of Science, v. 259, no. 8, p. 583-611. 
Watkins, N.D., and Baksi, A.K., 1971, Magnetostratigraphy and oroclinal folding of the Columbia River, Steens, and Owyhee basalts in Oregon, Washington, and Idaho: American Journal of Science, v. 274 , p. $148-189$.

Wel1s, F.G., and Peck, D.L., 1961, Oregon west of the 121st meridian: U.S. Geological Survey Miscellaneous Geologic Investigations Map I -325 .

Wright, T.L., Grolier, M.J., and Swanson, D.A., 1973, Chemical variation related to the stratigraphy of the Columbia River Basalt: Geological Society of America Bulletin, v. 84, no. 2, p. 371-386.

Zietz, I., Hearn, B.C., Jr., Higgins, M.W., Robinson, G.D., and Swanson, D.A., 1971, Interpretation of an aeromagnetic strip across the northwestern United States: Geological Society of America Bulletin, v. 82, p. 3347-3372. 


\section{APPENDIX A}

\section{INSTRUMENTAL NEUTRON ACTIVATION ANALYSIS PROCEDURES}

Instrumental Neutron Activation Analysis (INAA) is a quantitative technique for measuring the concentrations of elements in a sample by determining the frequency with which gamma rays are emitted from radioactive nuclides. The gamma ray energy plus the nuclide half life distinguish the nuclide in question; the frequency is related to the activity of the element and thus to the concentration.

Each representative rock sample was crushed, and $16 \mathrm{~g}$ of fresh, uncontaminated fragments were ground by hand into a coarse powder passing an 80 mesh sieve. From the $16 \mathrm{~g}$, approximately one gram of sample was split out randomly and stored in a clean one dram plastic vial for irradiation in a thermal neutron reactor (Reed College TRIGA reactor). By absorption of a thermal neutron, the product nuclide becomes an isotope of the target element. This product nuclide is in an excited state and deexcites by emission of a gamma ray of a discrete energy level characteristic of the nuclide at a rate governed by the nuclide's particular half life. Because different nuclides have peaks of decay activity at different times, the activity of the samples was measured twice to account for both the long-lived (half lives of weeks to years) and short-lived (half lives of minutes to days) isotopes at time intervals appropriate to the half lives of the nuclides being studied. 
The activity, or number of disintegrations per second as indicated by the rate of emission of gamma rays, was measured with a Lithiumdrifted Germanium crystal [Ge(Li)] detector and a Tracor Northern 1808 multichannel analyzer. This system is designed to determine concentrations based on an absolute counting method using the flux data for calibration rather than rock standards for comparison. A mixture of Iron-58, Iron-59, and Ruthenium was irradiated as a flux monitor. However, this technique requires that the detector efficiency be well known. As a check, standards were irradiated under the same conditions as the samples to provide very accurately known concentrations of elements for calibration and comparison. This experiment used both the U.S. Geological Survey-determined BCR-1, using elemental concentrations as listed in Flanagan (1973), and the Atlantic Richfield Archo-1, using concentrations listed in Additon and Seil (1979). Values measured for the standards in the experiment were approximately 1.5 times greater than the published values, and individual element correction factors were applied to all results. Most of the errors associated with INAA are statistical counting errors, and such errors were calculated for each element in each sample.

A total of 38 rock samples were analyzed by this method in a single experiment $7-B$ in June, 1980. Irradiation lasted one hour, starting at 10:00 am on June 20, 1980. Samples were counted first between June 25-27 and later between July 19-23, 1980, for 1000 and 2500 seconds, respectively. 
APPENDIX 3

SAMPLE LOCATIONS

Sample Location

$V P-1$

$V P-2$

$V P-3$

$V P-4$

VP-5

$V P-6$

VP-7

$V P-8$

VP-10

VP-11

VP-12

VP-13

VP-14

VP-15

VP-16

VP-17

VP-18

$V P-19$

$V P-20$

$V P-21$

VP-22

$V P-23$

$V P-24$

$V P-25$

VP-26

VP-27

$V P-28$

VP-29

VP-30

VP-31

$V P-32$

$V P-33$

VP-34

VP-35

$V P-36$

VP-37

VP-38
$\mathrm{SEl} / 4 \mathrm{NWT} / 4 \mathrm{sec} .28$, T. $7 \mathrm{~N} .$, R. $8 \mathrm{~W}$. $\mathrm{SEl} / 4 \mathrm{NW} / 4 \mathrm{sec}, 2, \mathrm{~T}, 6 \mathrm{~N}, \mathrm{R}, 8 \mathrm{~W}$. NWT/4 NWT/4 SE 1/4 sec. 11, T. 4 N, , R. $7 \mathrm{~W}$, SW1/4 NW1/4 sec. 32, T. 6 N., R. $7 \mathrm{~W}$. NW1/4 SW1/4 sec. 32, T. 6 N., R. $7 \mathrm{~W}$. $\mathrm{SW} 1 / 4 \mathrm{SW} / 14 \mathrm{sec}, 22, \mathrm{~T} .7 \mathrm{~N}$, , R. $9 \mathrm{~W}$. SEl/4 SWT/4 sec. $27, T .7$ N., R, 9 W. SW1/4 sec, 29, T. $9 \mathrm{~S}$, , R, $11 \mathrm{~W}$. $\mathrm{SEl} / 4 \mathrm{SEl} / 4 \mathrm{sec}, 34, \mathrm{~T}, 7 \mathrm{~N}, \mathrm{R}, 9 \mathrm{~W}$. $\mathrm{SEl} / 4 \mathrm{sec} .25, \mathrm{~T} .12 \mathrm{~S} ., \mathrm{R} .12 \mathrm{~W}$.

$\mathrm{NEl} / 4 \mathrm{NEl} / 4 \mathrm{sec}, 13, \mathrm{~T}, 7 \mathrm{~N} ., \mathrm{R} .9 \mathrm{~W}$. $\mathrm{NEl} / 4 \mathrm{NEl} / 4 \mathrm{sec} .13, \mathrm{~T}, 7 \mathrm{~N} ., \mathrm{R}, 9 \mathrm{~W}$, $\mathrm{NEl} / 4 \mathrm{NW} / 4 \mathrm{sec} .7, \mathrm{~T}, 6 \mathrm{~N} ., \mathrm{R} .7 \mathrm{~W}$, SWI/4 SWI/4 sec, 7; T. $5 \mathrm{~N}, ., \mathrm{R}, 10 \mathrm{~W}$. SEl/4 NWl/4 sec, $25, T, 5 \mathrm{~N},, \mathrm{R}, 8 \mathrm{~W}$. NW1/4 SE1/4 sec, 17, T. 5 N., R. 8 W. SWT/4 SEl/4 sec, 33, T. $6 \mathrm{~N}$, , R. $10 \mathrm{~W}$. $\mathrm{NE}$ / 4 NWT/4 sec. 4, T. $5 \mathrm{~N} ., \mathrm{R} .10 \mathrm{~W}$. NWT $/ 4 \mathrm{NET} / 4 \mathrm{sec}, 17, \mathrm{~T}, 8 \mathrm{~N} ., \mathrm{R}, 9 \mathrm{~W}$. SW1/4 SWl/4 sec. $34, T, 7$ N., R. 8 W. SEl $/ 4$ SW $1 / 4$ sec. $34, T, 7$ N., R. 8 W. $\mathrm{NE} 1 / 4 \mathrm{NW} / \mathrm{4} \mathrm{sec} .33, \mathrm{~T}, 6 \mathrm{~N}, \mathrm{R}, 8 \mathrm{~W}$. SWl $/ 4$ SWl $/ 4$ sec. $34, T, 7$ N., R, 8 W. $\mathrm{NEl} / 4 \mathrm{SW} / 4 \mathrm{sec}, 18, \mathrm{~T}, 5 \mathrm{~N}, \mathrm{R}, 8 \mathrm{~W}$. SW1 $/ 4 \mathrm{NW} 1 / 4 \mathrm{sec} .4, T .5 \mathrm{~N} ., \mathrm{R} .7 \mathrm{~W}$. NW1/4 NW1/4 sec, 4, T. 5 N., R. 7 W. C W1/2 sec, 20, T. 6 N., R, 6 W. $\mathrm{NE} 1 / 4 \mathrm{NW} 1 / 4 \mathrm{sec} .29, \mathrm{~T}, 7 \mathrm{~N}, \mathrm{R}, 9 \mathrm{~W}$. $\mathrm{NEl} / 4 \mathrm{SEl} / 4 \mathrm{sec} .35, \mathrm{~T}, 7 \mathrm{~N}$, , R. $8 \mathrm{~W}$, SW1/4 SWl 4 sec. $27, T, 7$ N., R. 8 W. NW1/4 SWl/4 sec. $25, T, 5 \mathrm{~N},, \mathrm{R}, 8 \mathrm{~W}$, SW1/4 SW1/4 sec. $35, T, 7$ N., R, 8 W, $\mathrm{SEl} / 4 \mathrm{NEl} / 4 \mathrm{sec}, 22, \mathrm{~T}, 5 \mathrm{~N}, \mathrm{R}, 8 \mathrm{~W}$, $\mathrm{SEl} / 4 \mathrm{SEl} / 4 \mathrm{sec}$ 2, T. $6 \mathrm{~N} ., \mathrm{R} .8 \mathrm{~W}$, $\mathrm{NW} 1 / 4 \mathrm{SEl} / 4 \mathrm{sec} .28, \mathrm{~T} .7 \mathrm{~N}, \mathrm{R}, 8 \mathrm{~W}$. C N1/2 sec. $33, T, 6 \mathrm{~N}$, , R, $8 \mathrm{~W}$, SW1/4 SW1/4 sec, $22, T, 7$ N., R, 9 W. 


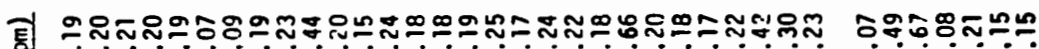

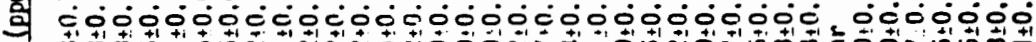
J

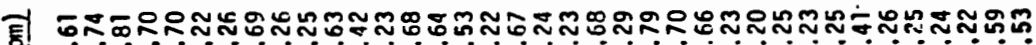

g

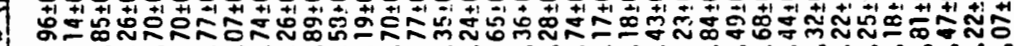

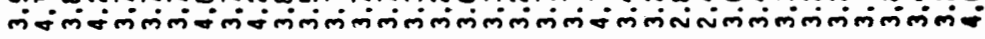

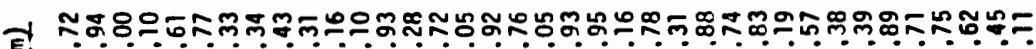

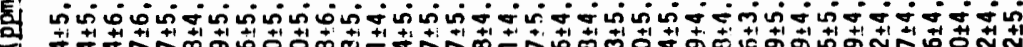

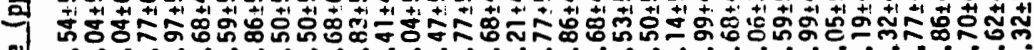

ㄴ

死

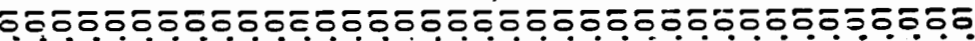

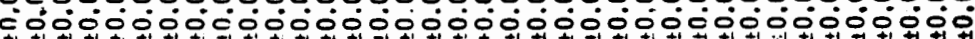

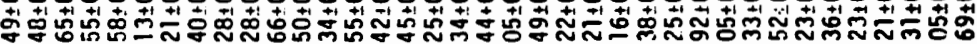

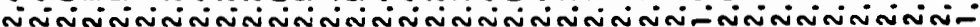

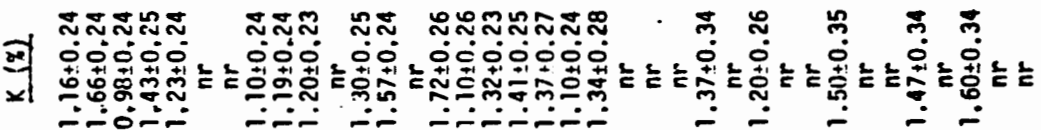

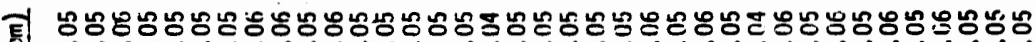

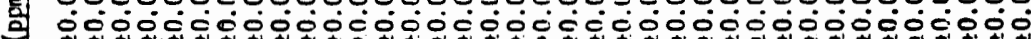

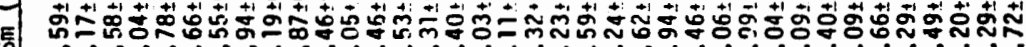

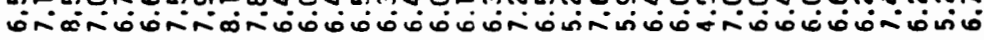

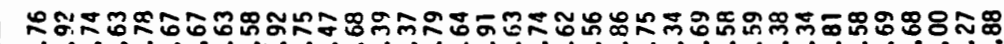

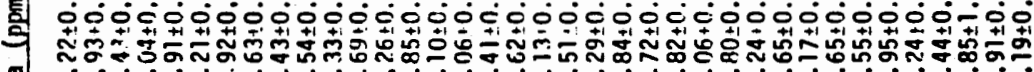

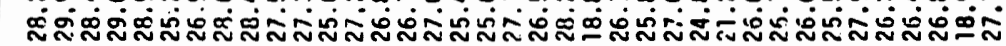

힘

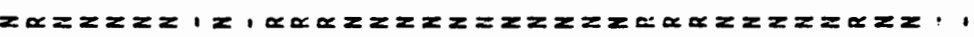

홍

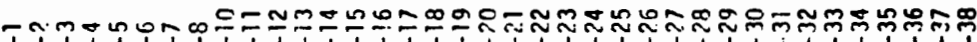

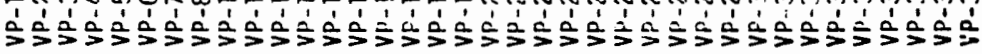




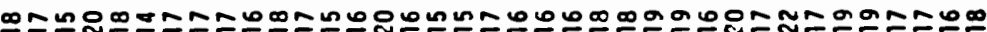

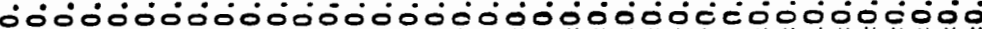

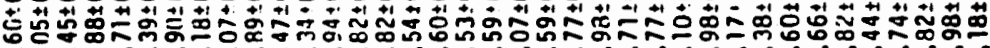

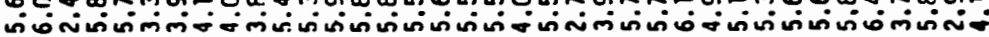

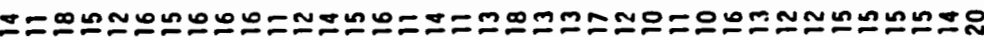
iojiojo

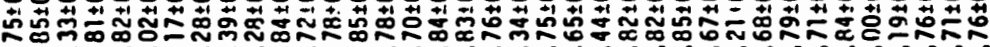
-

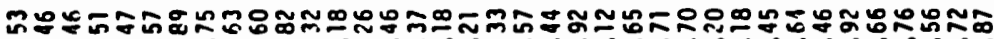

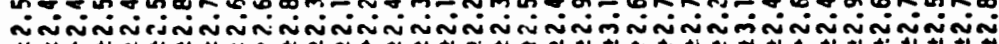

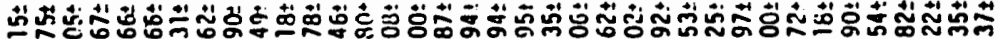

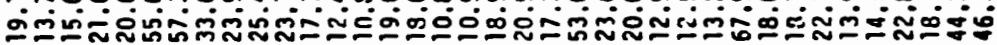

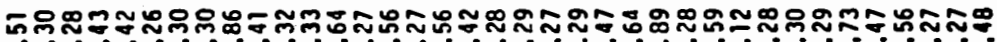
00000000000000000000000-0000000

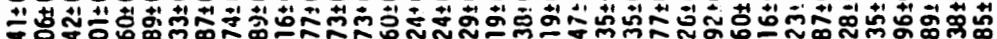

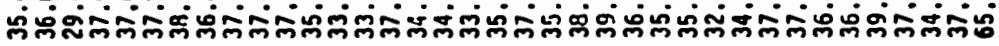

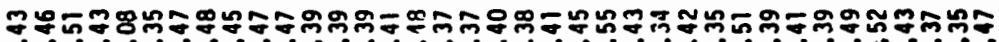

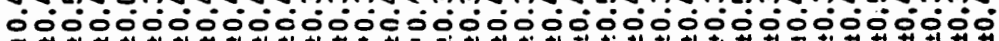

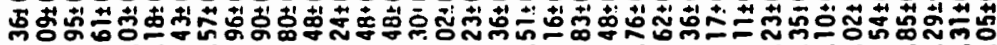

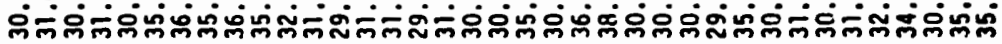

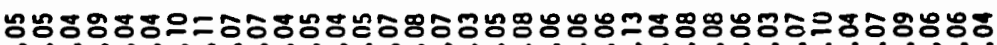

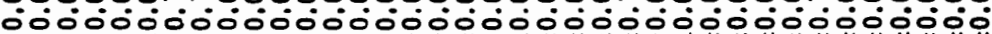

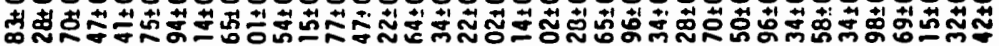

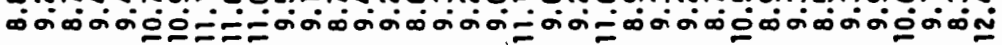

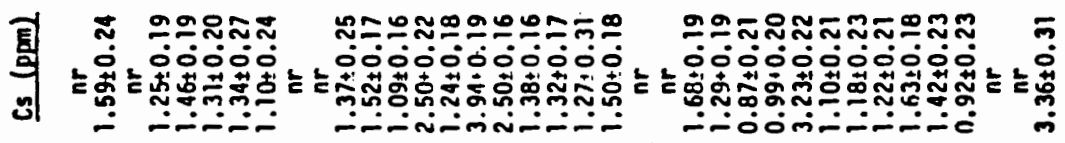

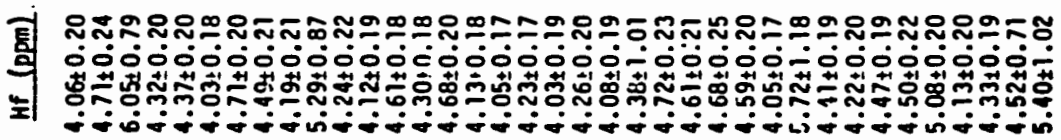

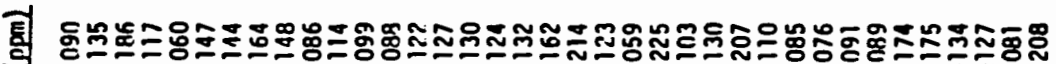

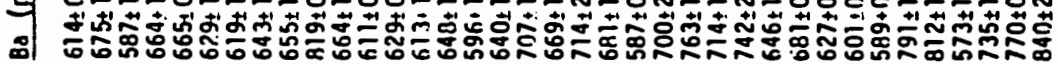

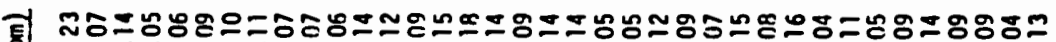

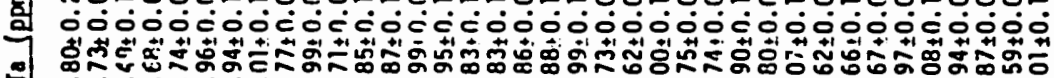

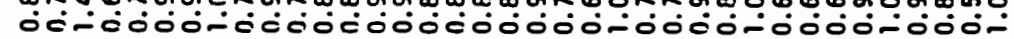

웋

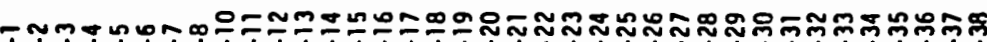

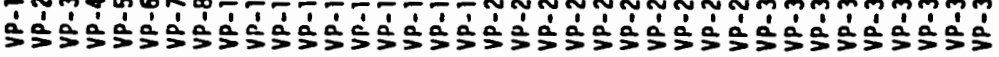


స్ర్య =

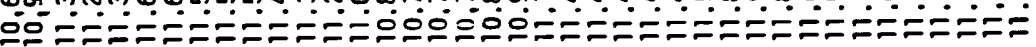

틀홍

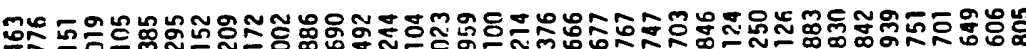
rió

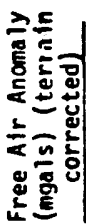

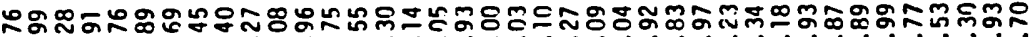

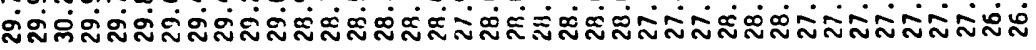

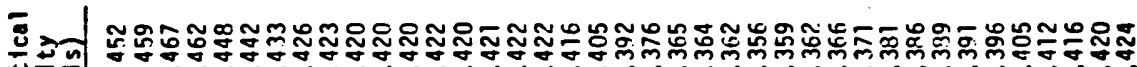
b

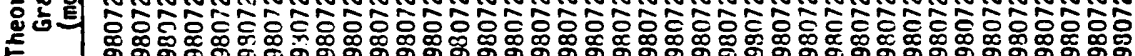

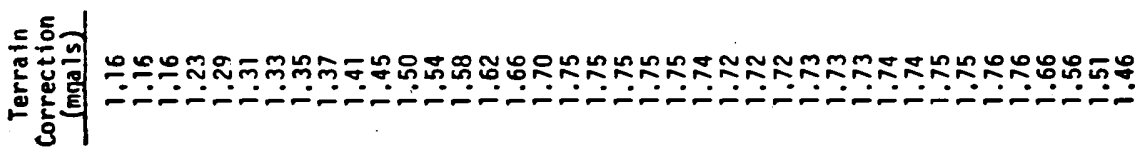

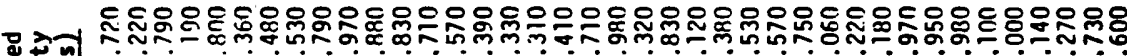

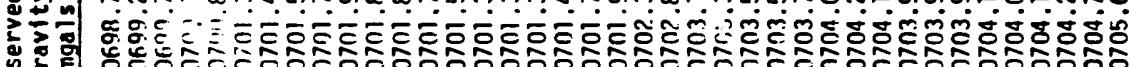

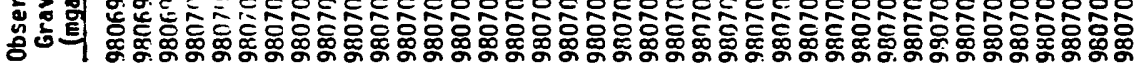

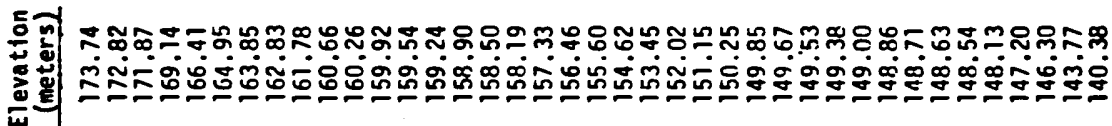

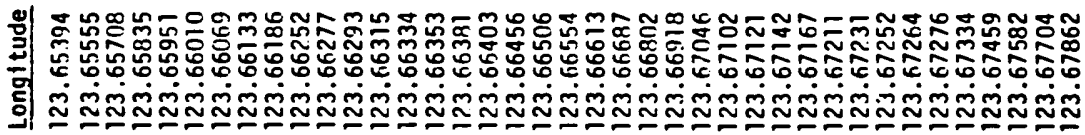

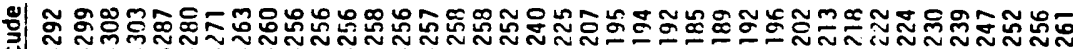

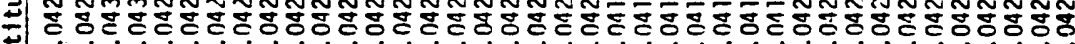

年

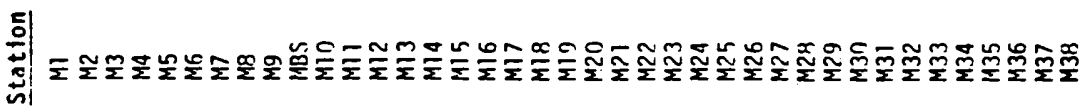




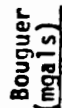

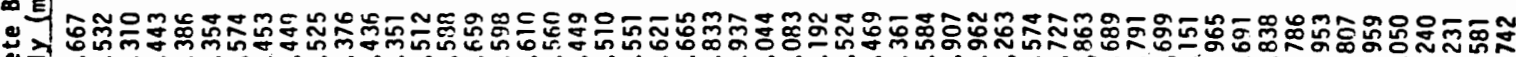
है용

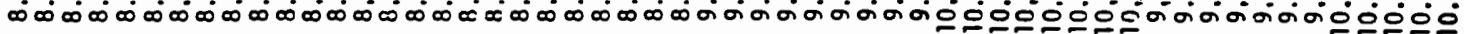

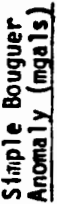

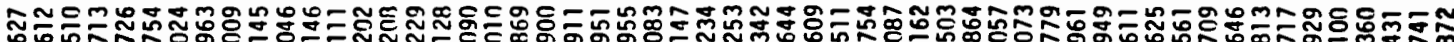

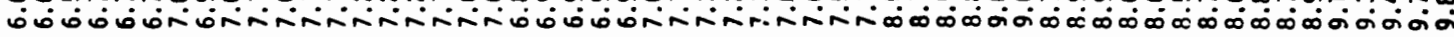
量言

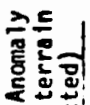

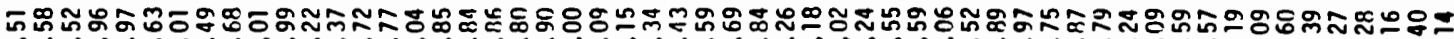
运贾

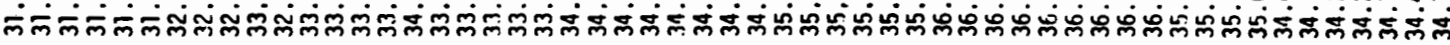

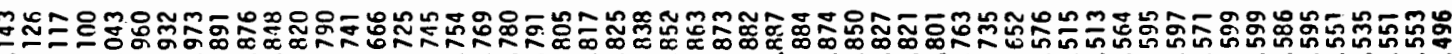

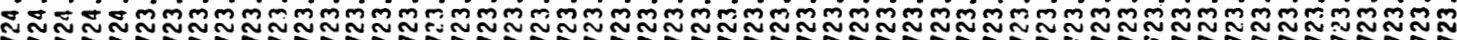

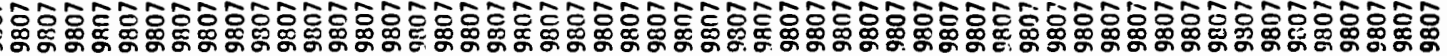

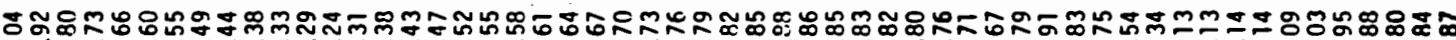

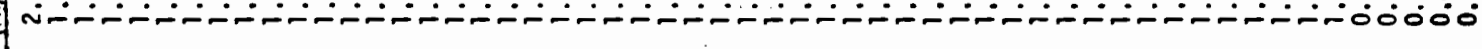

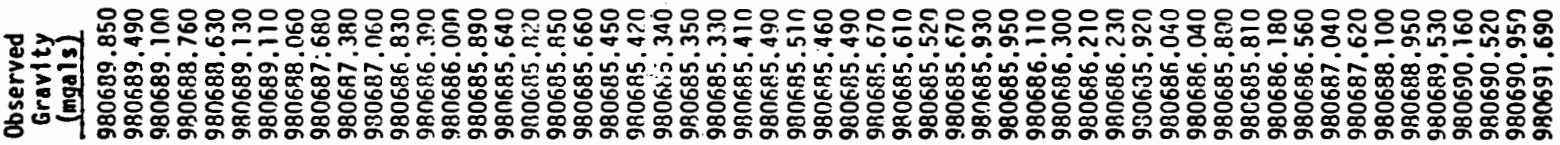

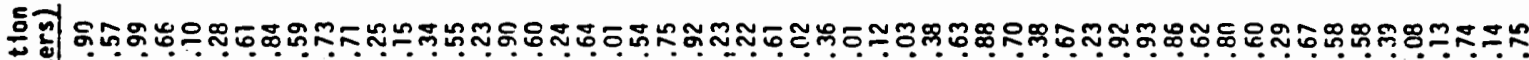

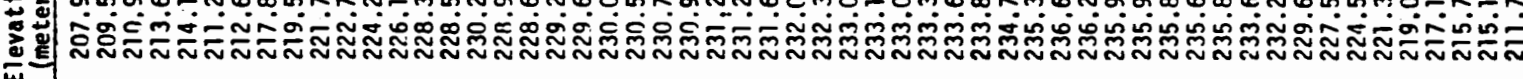

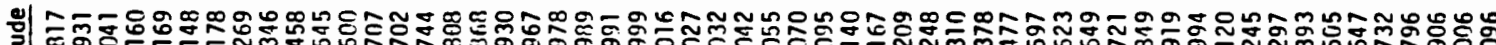

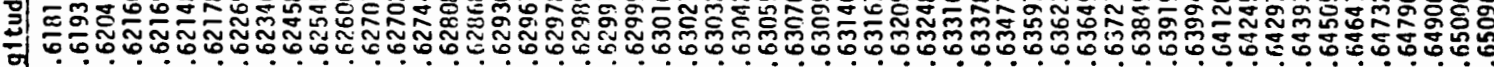
:

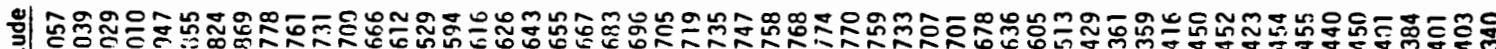

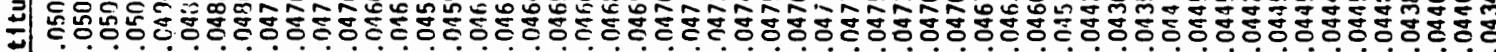
|

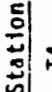

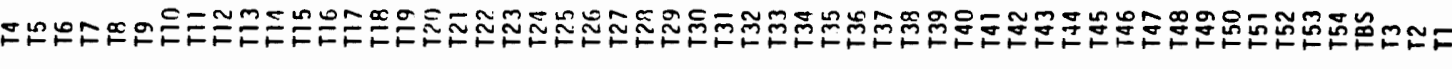




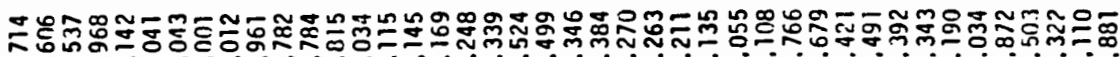

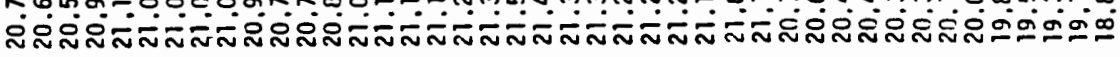

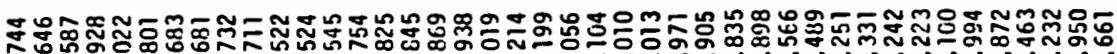

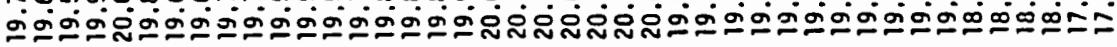

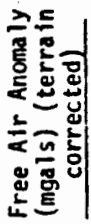

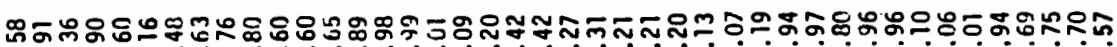

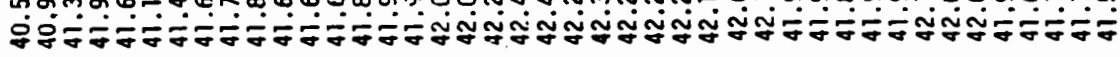

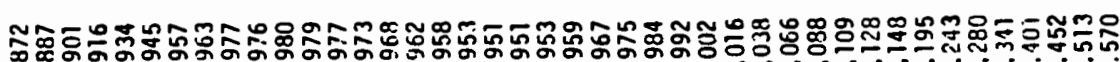

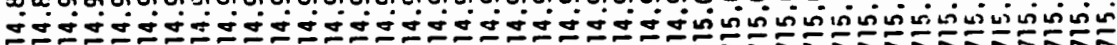

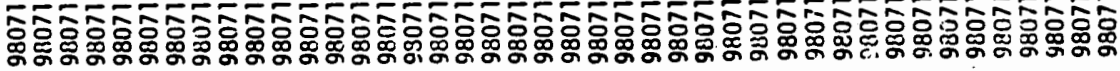

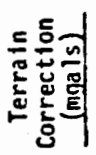

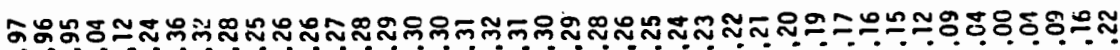

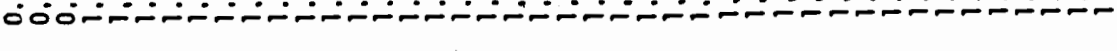

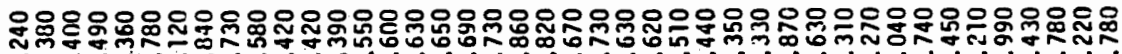

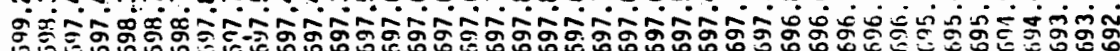

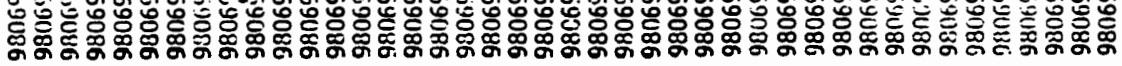

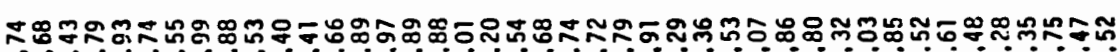

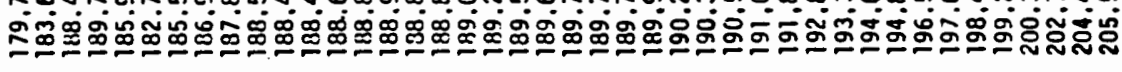

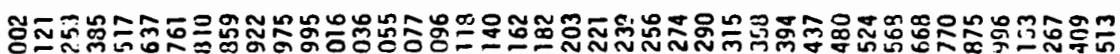

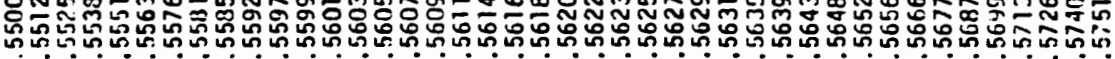

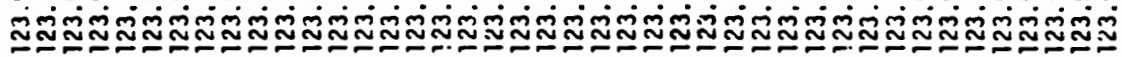

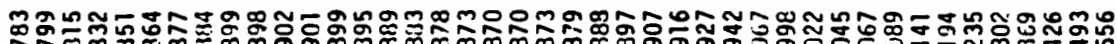
今̄

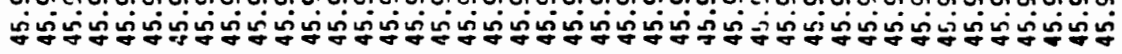




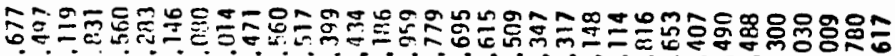
言产

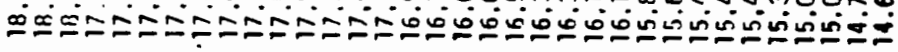

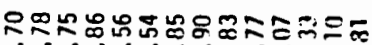

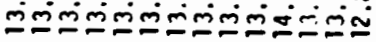

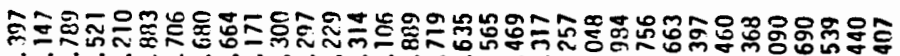

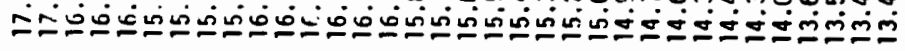

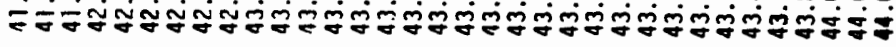

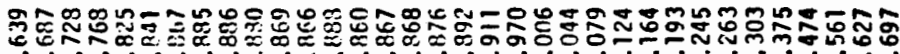
ن

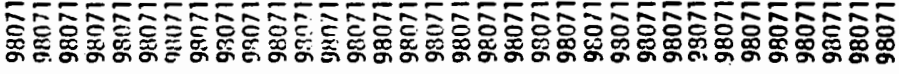

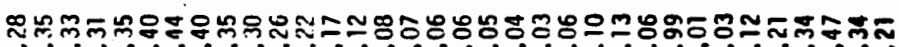

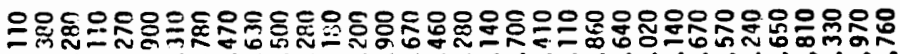

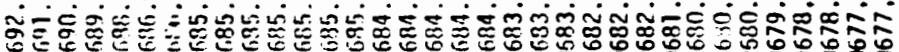

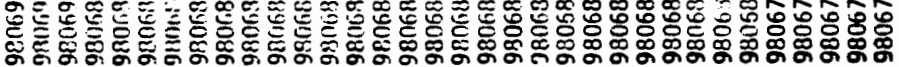

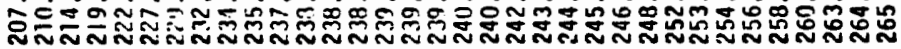

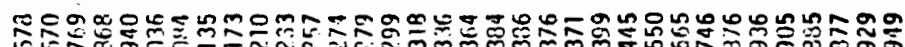

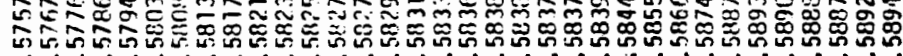

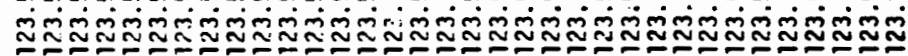

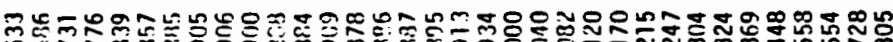
ڤ̆

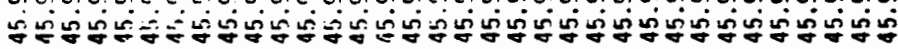

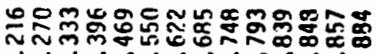

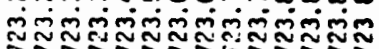

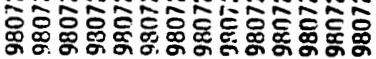

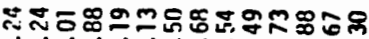

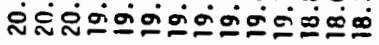

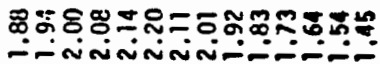

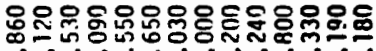

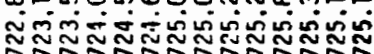

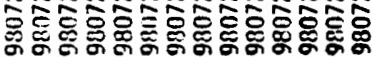

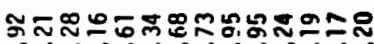

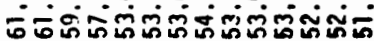

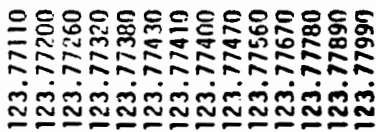

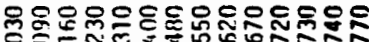

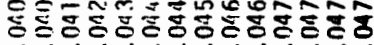

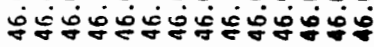

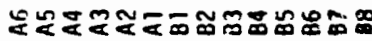


ํํㄹำ

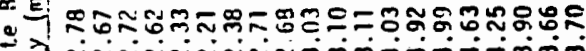

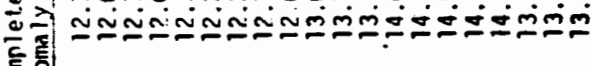

望

홀ํำ

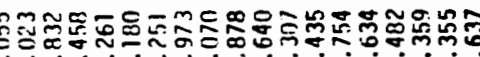

है

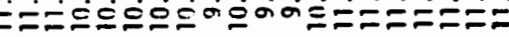

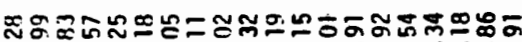

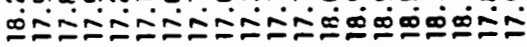

웅

置

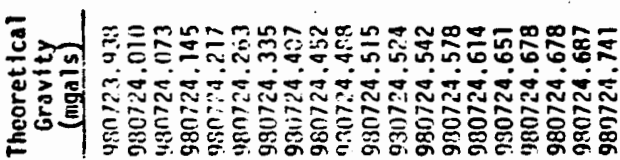

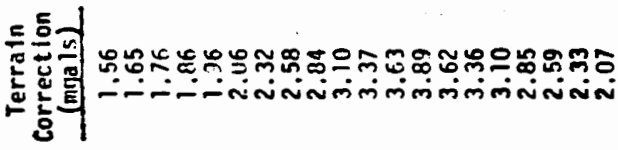

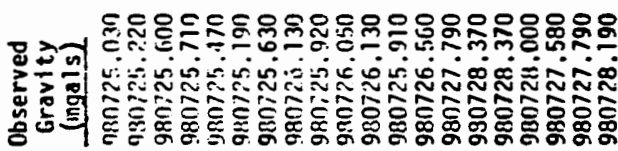

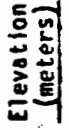

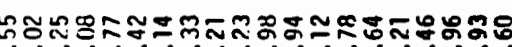

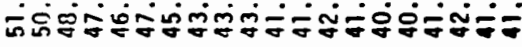

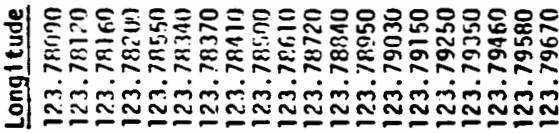

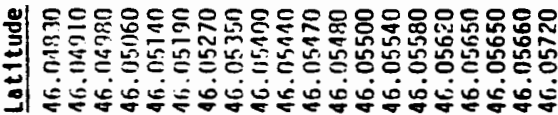

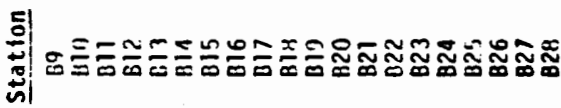

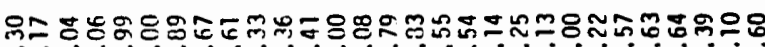

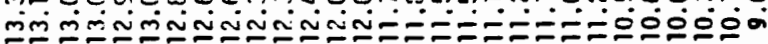

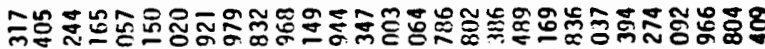

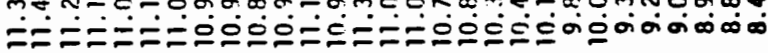

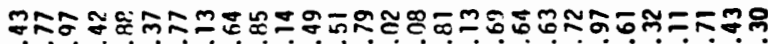

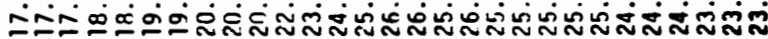

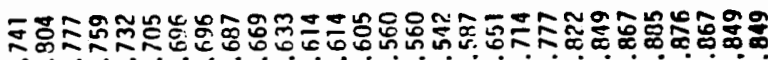

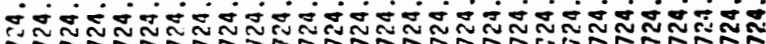

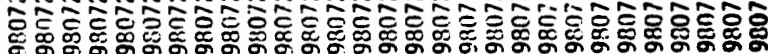

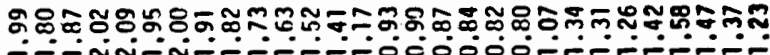

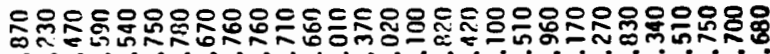

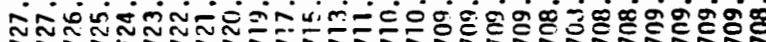

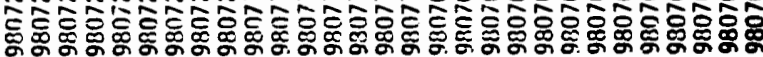

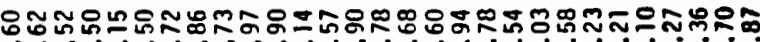

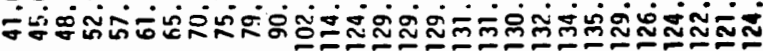

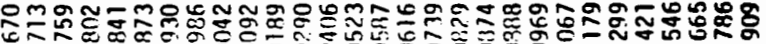

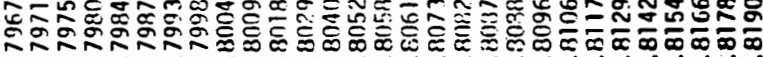

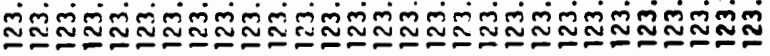

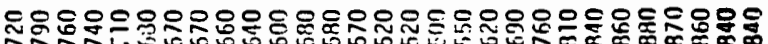

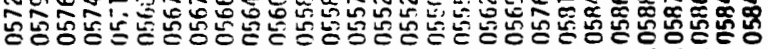

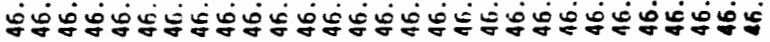

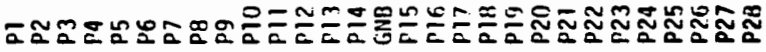


홀훌

용

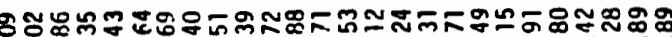

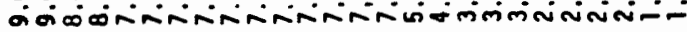

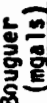

施害

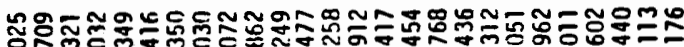

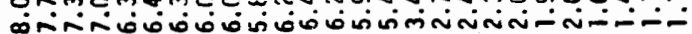

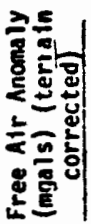

₹ロล

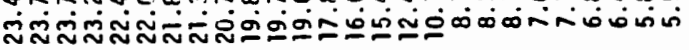

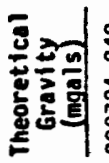

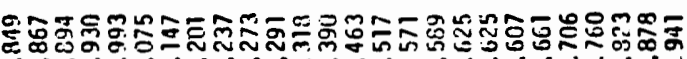

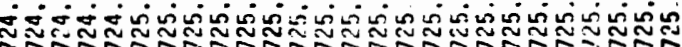

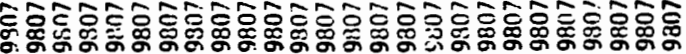

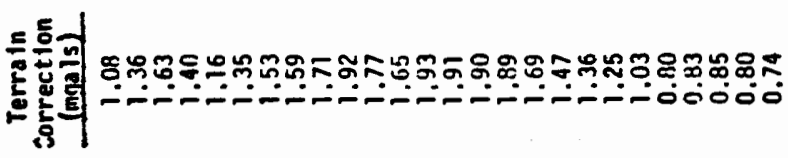

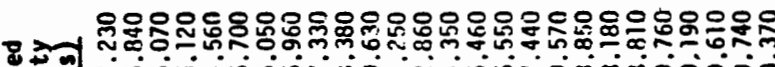

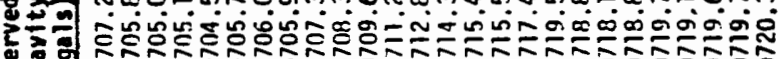

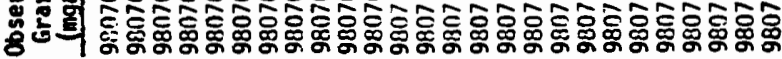

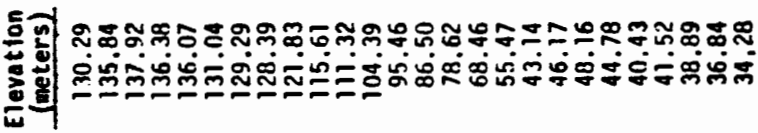

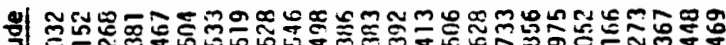

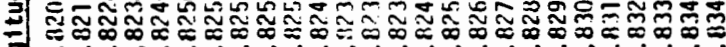

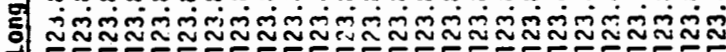

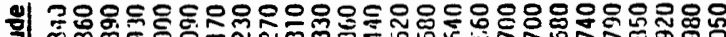
갱영.

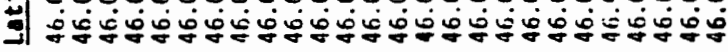

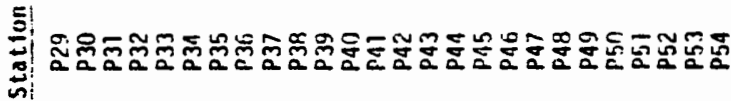

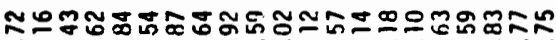

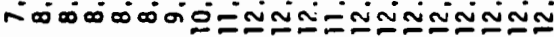

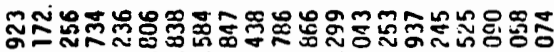

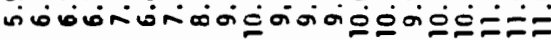

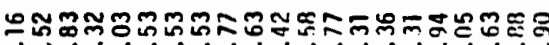

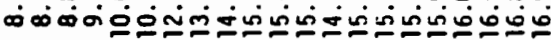

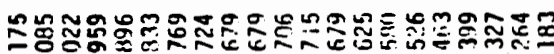

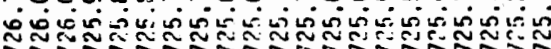

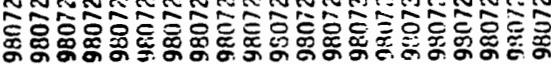

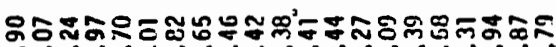

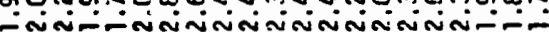

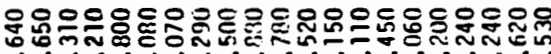
คำ

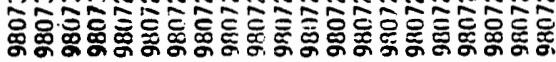

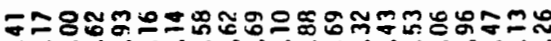

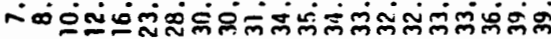

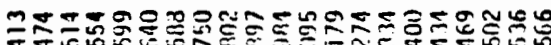

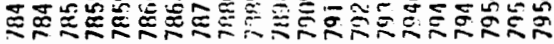

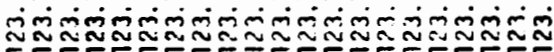

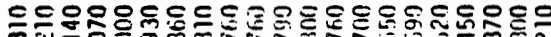

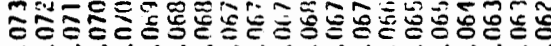

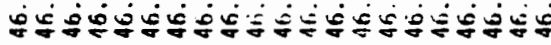

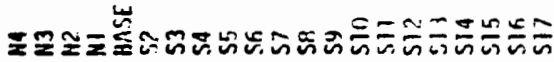




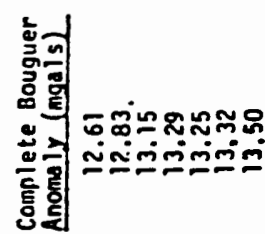
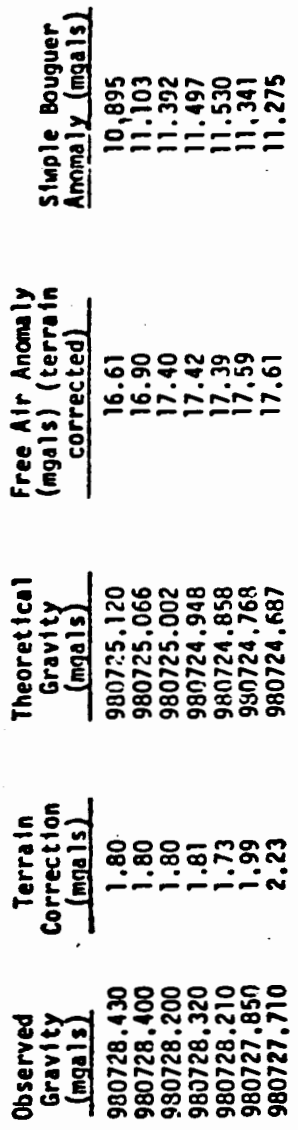

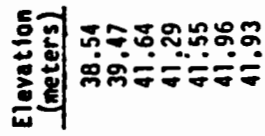
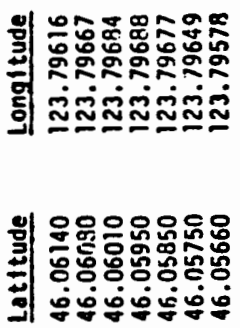

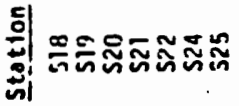

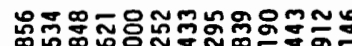

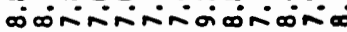

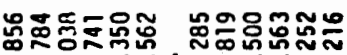

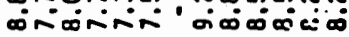

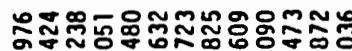

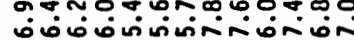

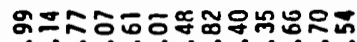

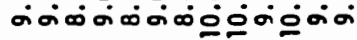

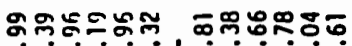
-

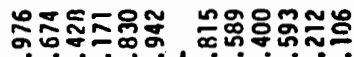
فn

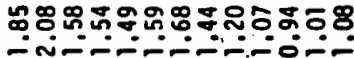

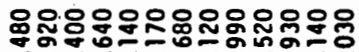

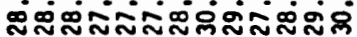

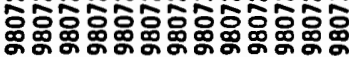

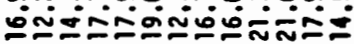

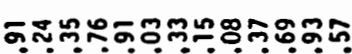

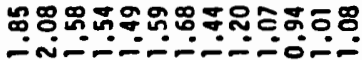

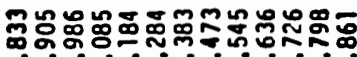
ஸ்

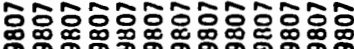

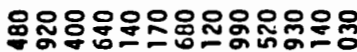

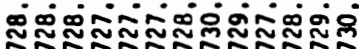

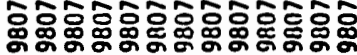

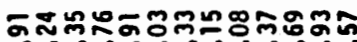

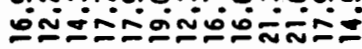

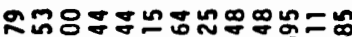

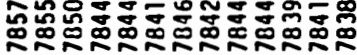

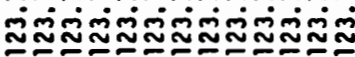

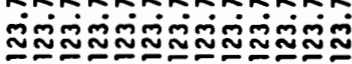

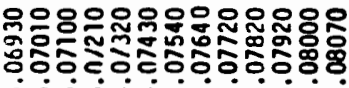
மி ف ف

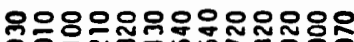

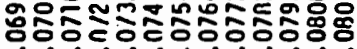

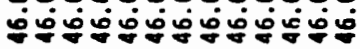

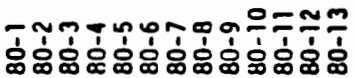

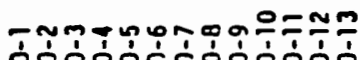

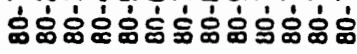




\section{APPENDIX E}

\section{ROCK UNITS USED IN GRAVITY MODELS}

Tillamook Volcanics: Eocene tholeiitic basaltic pillow lavas and flow and submarine breccias interbedded with minor tuffaceous siltstone and basaltic sandstone; unit thins away from its volcanic center (Tillamook Highlands), where it is up to $6100 \mathrm{~m}$ thick; equivalent to ocean floor basalt, forms basement rock of northwest Oregon; assigned a $2.8 \mathrm{~g} / \mathrm{cc}$ density by Snavely and Wagner (1964).

Upper Eocene Sedimentary Rock: overlies Tillamook Volcanics with probable unconformity; in upper Nehalem basin, Cowlitz Formation is $300 \mathrm{~m}$ of deep marine tuffaceous mudstone and subordinate arkosic sandstone, laminated siltstone, and basaltic conglomerate which interfingers with the late Eocene Goble Volcanics, porphyritic submarine and subaerial basalt flows, breccias, and pillow lavas; Cowlitz Formation assigned a $2.5 \mathrm{~g} / \mathrm{cc}$ density by Beeson and others (1976b); Goble Basalt assigned a $2.8 \mathrm{~g} / \mathrm{cc}$ density.

01 igocene-Miocene Sedimentary Rock: Toms unit of Schlicker and others (1972) and Beaulieu (1973); SnaveTy and Wagner (1964) treat the late Eocene to mid Miocene marine sedimentary rocks as a single geophysical unit of $2.4 \mathrm{~g} / \mathrm{cc}$ density, and they are treated as such both here and in Beeson and others (1976b); includes the following formations:

Keasey Formation: conformably (?) overlies Cowlitz; up to $600 \mathrm{~m}$ of stratified tuffaceous marine siltstone, mudstone, and shale with thin interbeds of glauconitic sandstone of late Eocene to early 01 igocene age;

Pittsburgh Bluff and Scappoose Formations: mid-0ligocene to early Miocene, $260 \mathrm{~m}$ and $460 \mathrm{~m}$ thick, respectively; Pittsburgh Bluff includes minor tuffaceous sandy siltstone and mudstone layers in thick arkosic and glauconitic sandstone beds with occasional layers of volcanic ash; disconformably overlying the Pittsburgh Bluff, the Scappoose is composed of arkosic sandstone with subordinate tuffaceous mudstone and basaltic conglomerate and less volcanic ash; partly equivalent to the coastal Oswald West Mudstones (silty mudstones and tuffaceous siltstones);

Astoria Formation: overlies older units with angular unconformity; up to $600 \mathrm{~m}$ of semi-consolidated to indurated deltaic and shallow marine micaceous arkosic and lithic sandstone and siltstone with interbeds of turbidite sandstone and mudstone. 
Columbia River Basalt Group and Miocene Coastal Basalts: mid to late Miocene; up to $600 \mathrm{~m}$ of tholeiitic basalt flows, breccias, and pillow lavas and intrusions; assigned a $2.8 \mathrm{~g} / \mathrm{cc}$ density by Snavely and Wagner (1964) and Beeson and others (1976b); bounded by angular unconformities.

Post Miocene Sedimentary Units:

Troutdale Formation: up to $275 \mathrm{~m}$ of poorly consolidated fluvial conglomerates and interbeds of sandstone and mudstone and siltstones; late Miocene to Pliocene; forms fill in structural basins (e.g., Tualatin Valley), where it may be greater than $300 \mathrm{~m}$ thick; assigned a $2.3 \mathrm{~g} / \mathrm{cc}$ density by Beeson and others (1976b);

Holocene Alluvium: floodplain alluvium and terraces of bedded basaltic gravels and/or silty clays along stream drainages; dune and beach sands, tidal flat muds and silts; up to $90 \mathrm{~m}$ thick, usually unconsolidated; assigned a $2.0 \mathrm{~g} / \mathrm{cc}$ density. 